\title{
53. PETROLOGIC EVOLUTION OF THE MARIANA ARC AND BACK-ARC BASIN SYSTEM- A SYNTHESIS OF DRILLING RESULTS IN THE SOUTH PHILIPPINE SEA ${ }^{1}$
}

\author{
James H. Natland, Deep Sea Drilling Project, Scripps Institution of Oceanography, La Jolla, California \\ and \\ John Tarney, Department of Geology, University of Leicester, LE1 7RH, United Kingdom
}

\begin{abstract}
The results of Deep Sea Drilling Project Leg 60 pertaining to the petrologic evolution of the Mariana Trough and Mariana arc are summarized in Part $\mathrm{I}$. The rocks recovered at five principal sites are exceptionally diverse, including gabbros and calc-alkalic andesites derived from the West Mariana Ridge; fresh and hydrothermally altered basalts in the Mariana Trough; and interbedded boninites and arc tholeiites in the forearc region between the modern arc and the trench. Part I outlines the stratigraphy, alteration, and petrology of these rock suites and summarizes hypotheses on their origin.

Part II integrates these results with those of previous DSDP legs in the region, and with island sampling, to present a composite 40-m.y. history of the Mariana arc system. Arc volcanism began in the Eocene, probably as a result of a change to the west in the motion of the Pacific plate. A north-south-trending fracture zone was transformed into a trench-subduction complex, trapping a portion of the Pacific plate in the Philippine Sea. The crust of this basin, drilled in Hole 447 (Leg 59), has the composition of typical ocean floor basalt.

The earliest Eocene arc was built up dominantly of arc tholeiite and boninitic lavas, with lesser calc-alkalic lavas, based on the results of Leg 60 drilling at Sites 458 and 459 in the forearc region; Leg 59, Site 448, on the Palau-Kyushu Ridge; and exposures on the islands of Palau, Guam, and Saipan. Near Sites 458 and 459, the forearc crust is thin, formed entirely under water, and includes no known component of ocean crust. Nevertheless it has many of the features of an ophiolite, produced in situ by earliest arc volcanism. In the Miocene, the Palau-Kyushu Ridge was split from this ancestral arc by opening of the Parece Vela back-arc basin. A new arc formed on the east side of this basin, the West Mariana Ridge. Lavas recovered from this ridge at Sites 451 and 453, and dating from this time on Guam, have calc-alkalic compositions. In the Pliocene, a second back-arc basin formed, the Mariana Trough, splitting off the West Mariana Ridge and causing volcanism along it to cease. The present arc has been built again on the east side of the new back-arc basin. Based on the compositions of ash at Site 453 and island exposures, the new arc first erupted arc tholeiites but has shifted to calc-alkalic compositions in the past 200,000 years. Both the Parece Vela Basin and Mariana Trough contain tholeiitic basalts with most of the features of mid-ocean-ridge tholeiites, but basalts in the Trough have some of the trace element characteristics of island arc basalts.

Petrogenetic models for the evolution of the arc system therefore must provide for four distinctive magma typesboninites, arc tholeiites, calc-alkalic lavas, and back-arc-basin tholeites-and explain their distribution in time and space. The relative contributions to the production of these magma types of the subducted slab, the overlying mantle wedge composition, partial melting, and fractional crystallization need to be considered. One important conclusion is that segregation of cumulus gabbros at elevated $p\left(\mathrm{H}_{2} \mathrm{O}\right)$ such as those cored at Site 453 may be a major mechanism for producing calc-alkalic andesites in the Mariana arc system. Immediately following back-arc rifting, when sources of magma are quite shallow and heat flow is high, the conditions necessary for such fractionation would be unlikely to occur. Thus following each episode of back-arc basin rifting, arc volcanism should be tholeiitic. Only later will it become calc-alkalic. We also propose that progressive changes in the mantle beneath each arc resulting from voluminous extraction of basalts may contribute to conditions necessary for new episodes of back-arc rifting.
\end{abstract}

\section{GENERAL INTRODUCTION}

Deep Sea Drilling Project Leg 60 completed the transect of the Mariana arc-interarc basin system in the Philippine Sea, begun on Leg 59. Between them the two cruises successfully recovered basement samples from all the main physiographic features in the area (Fig. 1): the West Philippine Sea (Site 457), the Palau-Kyushu Ridge (Site 448), the Parece Vela Basin (Sites 449 and 450), the West Mariana Ridge (Sites 451 and 453), the Mariana Trough (Sites 454 and 456), the Mariana Ridge (Site 457), the Mariana forearc (Sites 458 and 459), and the wall of the Mariana Trench (Sites 460 and 461). Sites 453 through 461 were drilled during Leg 60 . Additionally, Leg 58 drilled basement samples from the Shikoku

\footnotetext{
${ }^{1}$ Initial Reports of the Deep Sea Drilling Project, Volume 60.
}

Basin (Sites 442, 443, and 444), which is a northward continuation of the Parece Vela Basin and roughly equivalent to it in age, and from the Daito Basin in the northern West Philippine Sea (Site 446). The petrological and geochemical information now available for these samples, together with that assembled as a result of field investigations and dredging operations, provides a body of data more comprehensive than that available for any other arc-marginal basin system.

We have divided this chapter into two parts. In Part I, we summarize the results of basement drilling during Leg 60, drawing together principal results from all contributions to this volume dealing with basement samples. These results concern not only primary petrogenesis, but basement structure and alteration as well. In Part II, we review the primary geochemical data from Legs 58,59 , and 60 in relation to possible models for the petrological evolution of island arc-marginal basin sys- 


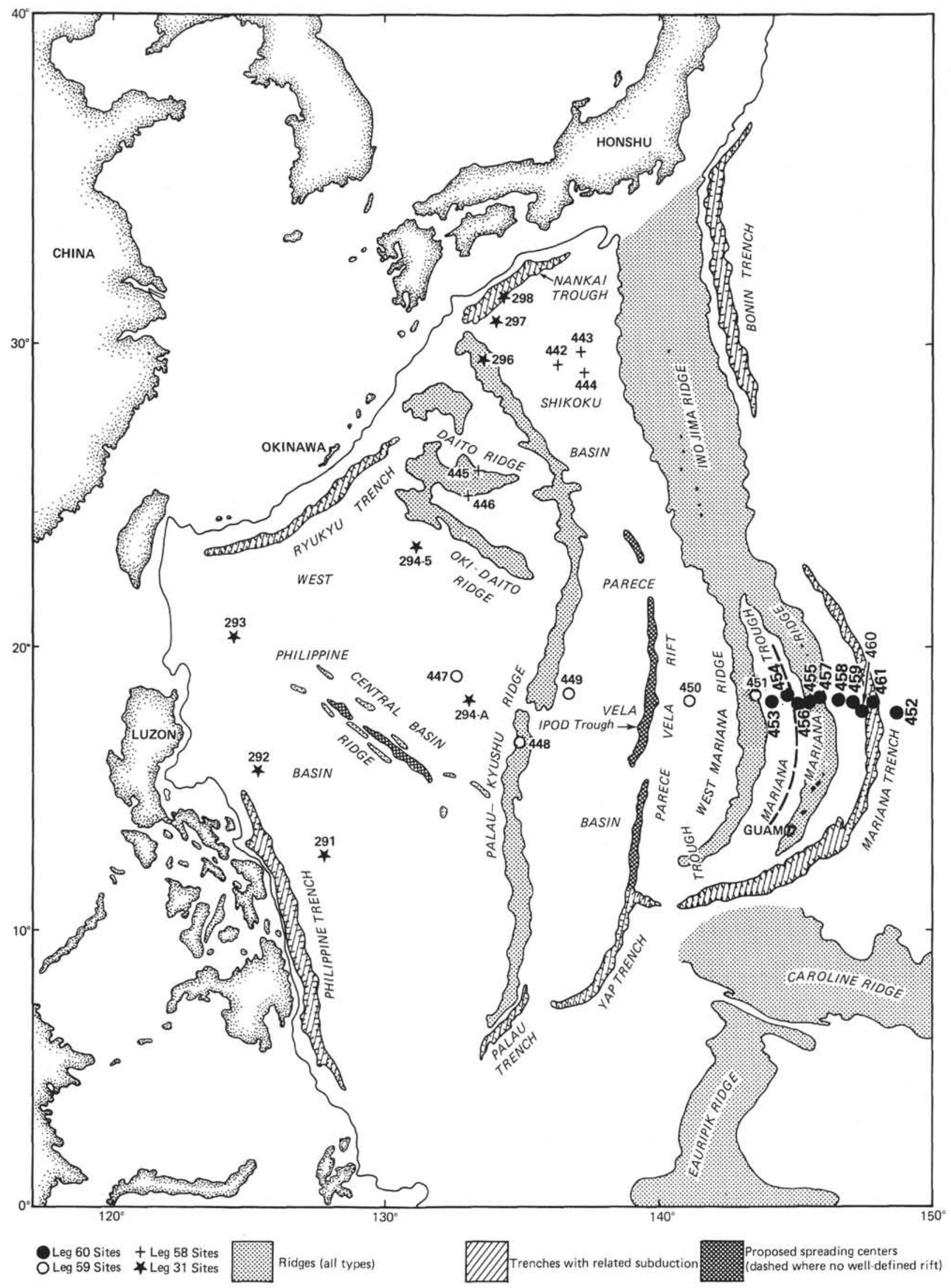

Figure 1. Location of DSDP sites drilled in the Philippine Sea. Site survey targets (SP numbers) are also indicated. 
tems and for the Mariana-Bonin arc system in particular. A considerable body of geophysical and tectonic data is already available for the Philippine Sea and forms a valuable background on which to construct petrological-geochemical models for the evolution of intraoceanic island arcs. In addition, the sedimentary history of the drill sites provides information about the timing and patterns of volcanism and interarc basin rifting, refining considerably the original interpretations of Karig (1971a, 1971b, 1975). These will be the principal concerns of this report.

\section{PART I. SUMMARY OF PETROLOGICAL INVESTIGATIONS BASED ON LEG 60 DRILLING}

\section{Leg 60 Basement Drilling Data}

Site locations, water depth, depth of basement, and recovery data for basement drilled during Leg 60 are given in Table 1. Altogether, basement drilling was very successful. Over 600 meters total basement penetration was obtained at five principal sites, and a variety of rock types were recovered. The following sections summarize the principal results pertaining to igneous basement for each site. Where applicable, the various lithologic, chemical, and magnetic units are defined, and a summary of the principal petrological and geochemical features of the rocks, as well as the state of their alteration, is given. Relevant geophysical information from site and other surveys and from shipboard programs (mainly heat flow) is considered. Additional interpretation of regional tectonic history in light of the drilling is in the synthesis by Hussong and Uyeda (this volume).

\section{Drilling in the Mariana Trough}

Four sites (453-456) were drilled in the Mariana Trough (Fig. 1) in an effort to find a location where a deep penetration multiple reentry hole could be drilled and to establish the spreading history of this youngest Mariana back-arc basin. Although no reentry site was found, igneous and metamorphic rocks were recovered in four holes at three sites. Site 453 was located in a small north-trending sediment pond on the western side of the Trough. A complex gabbro-metabasalt polymict breccia was cored for 146 meters beneath 450 meters of turbiditic vitric tuffs ranging in age from late Pliocene to Recent. Pillow basalts underlying Pleistocene sediments were cored nearer the center of the Trough in
Holes 454A, 456, and 456A. The latter two holes were about 200 meters apart. In each of these holes, basement penetration was low, and hole instabilities precluded reentry. Detailed operational, lithologic, and petrographic summaries of the rocks recovered in all these holes can be found in the site chapters.

\section{Polymict Breccias at Site $\mathbf{4 5 3}$}

Three types of igneous and metamorphic rock sequences were recovered in Hole 453. The upper two are breccias containing coarse cobbles or boulders of igneous and metaigneous rocks (Fig. 2). The deepest is a sheared and highly altered gabbro, recovered in two fragments totalling $150 \mathrm{~cm}$ in length. Gabbros and metabasalts occur in the upper breccia ( $86 \mathrm{~m}$ thick) with rare minor lithologies, including both foliated and nonfoliated quartz diorite (Sharaskin, this volume). Some gabbro clasts reach $40 \mathrm{~cm}$ in longest cored diameter, and where such large boulders are abundant, core recovery is highest. Metabasalts are either aphyric or have large recrystallized plagioclase phenocrysts. There are no large metabasalt boulders, although cores contain intervals where several adjacent metabasalt pieces evidently came from the same boulder.

The lower breccia contains aphyric greenstones, some quite pyritized, with the compositions of metamorphosed andesites and dacites (Wood et al., this volume). The rocks are small $(3-7 \mathrm{~cm})$, pale green, and are associated with a small amount of indurated pyroclastic breccia, also metamorphosed, and soft, dark green, friable breccia, perhaps originally a hyaloclastite. Some of the lithic fragments are veined with epidote.

The rocks have experienced a variety of low- and high-grade metamorphic events. The highest grade of metamorphism is represented by gabbros containing anorthite, green aluminous amphibole, and green hercynitic spinel (see Natland, gabbros chapter, this volume). Some gabbros have been completely recrystallized to prehnite-clinozoisite-plagioclase assemblages. Others have been partially recrystallized to chlorite and actinolite, with almost complete transformation of mafic minerals but only partial sericitization of plagioclase. Still other gabbros shows tectonized fabrics, including extensive development of (100) twinning on clinopyroxene, and bent plagioclase crystals. Greenschist facies metamorphic conditions evidently also affected the metabasalts, which contain groundmass andesine-oligoclase,

Table 1. Basement drilling and recovery data, Leg 60 .

\begin{tabular}{|c|c|c|c|c|c|c|c|}
\hline \multirow{2}{*}{$\frac{\text { Hole }}{453}$} & \multicolumn{2}{|c|}{ Location } & \multirow{2}{*}{$\begin{array}{c}\begin{array}{c}\text { Water } \\
\text { Depth } \\
(\mathrm{m})\end{array} \\
4693\end{array}$} & \multirow{2}{*}{$\begin{array}{c}\text { Depth to Basement } \\
\text { from Seafloor }\end{array}$} & \multirow{2}{*}{$\begin{array}{c}\begin{array}{c}\text { Basement } \\
\text { Cored } \\
(\mathrm{m})\end{array} \\
149.50\end{array}$} & \multirow{2}{*}{$\begin{array}{c}\begin{array}{c}\text { Basement } \\
\text { Recovered } \\
(\mathrm{m})\end{array} \\
33.30\end{array}$} & \multirow{2}{*}{$\begin{array}{c}\begin{array}{c}\text { Basement } \\
\text { Recovered } \\
(\%)\end{array} \\
22.3\end{array}$} \\
\hline & $17^{\circ} 40.17^{\prime} \mathrm{N}$ & $143^{\circ} 40.95^{\prime} E$ & & & & & \\
\hline $454 \mathrm{~A}$ & $18^{\circ} 00.78^{\prime} \mathrm{N}$ & $144^{\circ} 31.92^{\prime} \mathrm{E}$ & 3819 & 66.0 & $104.50^{\mathrm{a}}$ & 19.95 & 19.1 \\
\hline 456 & $17^{\circ} 54.68^{\prime} \mathrm{N}$ & $145^{\circ} 10.77^{\prime} \mathrm{E}$ & 3590.5 & 134.0 & 35.00 & 3.66 & 10.5 \\
\hline $456 \mathrm{~A}$ & $17^{\circ} 54.71 \cdot \mathrm{N}$ & $145^{\circ} 10.88^{\prime} \mathrm{E}$ & 3591 & 118.5 & 40.50 & 2.34 & 5.8 \\
\hline 458 & $17^{\circ} 51.84 \mathrm{~N}$ & $146^{\circ} 56.06^{\prime} \mathrm{E}$ & 3449 & 256.5 & 209.00 & 35.79 & 17.1 \\
\hline 459B & $17^{\circ} 51.75^{\prime} \mathrm{N}$ & $147^{\circ} 18.09^{\prime} \mathrm{E}$ & 4115 & 558.5 & 133.00 & 24.12 & 18.1 \\
\hline Totals & & & & & 671.50 & 119.16 & 17.7 \\
\hline
\end{tabular}

Note: Basement in Hole 453 is gabbro-metabasalt polymict breccia. At all other sites it is pillow lavas. Igneous and metamorphic rocks were also recovered as talus in Holes $460\left(17^{\circ} 40.14^{\prime} \mathrm{N} ; 147^{\circ} 37.92^{\prime} \mathrm{E}\right), 460 \mathrm{~A}$ $\left(17^{\circ} 40.02^{\circ} \mathrm{N} ; 147^{\circ} 35.16^{\prime} \mathrm{E}\right), 461\left(17^{\circ} 46.05^{\prime} \mathrm{N} ; 147^{\circ} 41.18^{\prime} \mathrm{E}\right)$, and $461 \mathrm{~A}\left(17^{\circ} 46.01^{\prime} \mathrm{N} ; 147^{\circ} 41.26^{\prime} \mathrm{E}\right)$, in water depths between 6443 and $7034 \mathrm{~m}$ in the Mariana Trench.

a Includes sediments interbedded with basalts. 


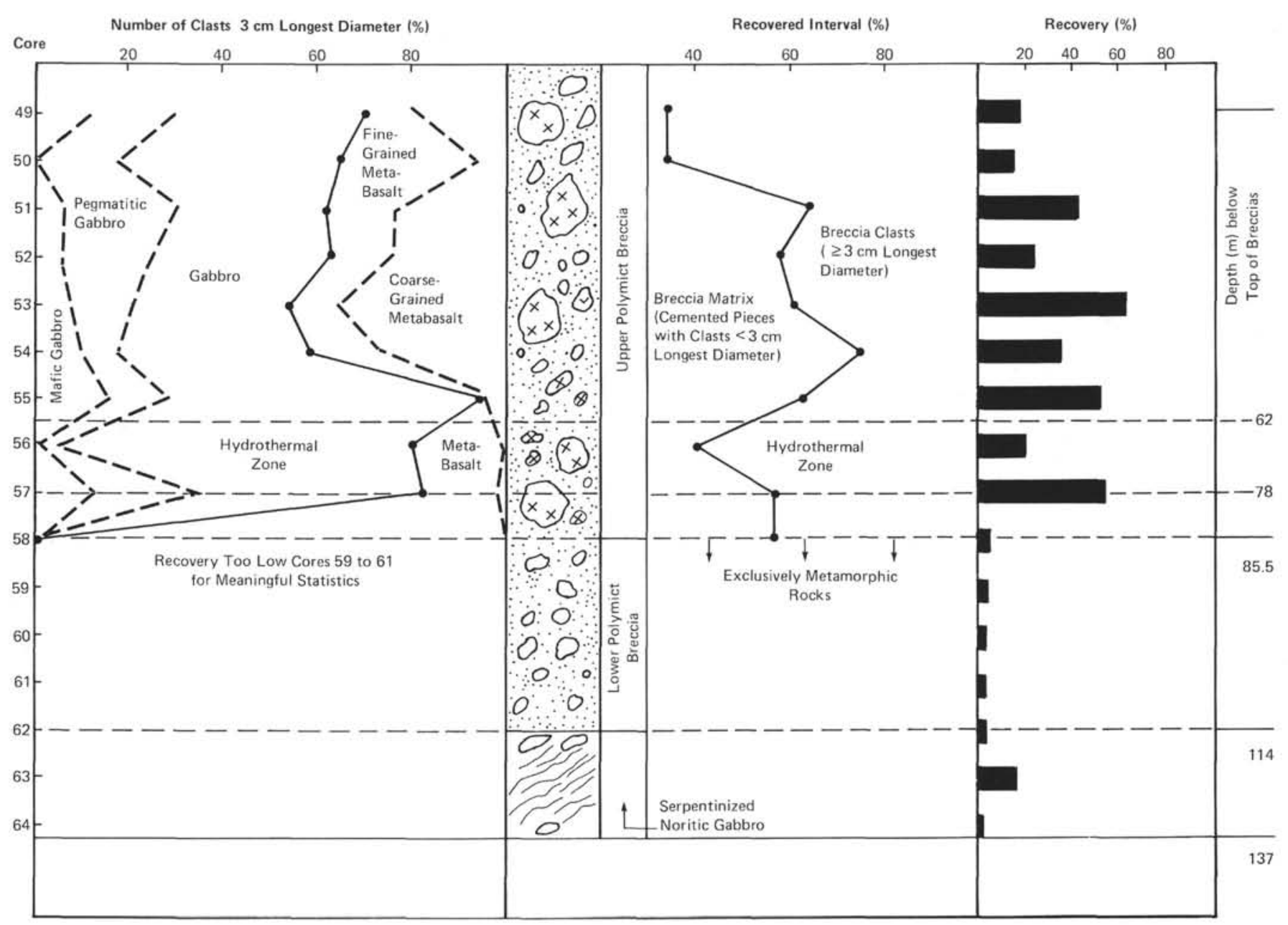

Figure 2. Stratigraphy, schematic lithology, and recovery per core of gabbro polymict breccias cored in Hole 453 .

amphibole, chlorite, epidote, clinozoisite, and sphene. They are not foliated but have granoblastic and porphyroblastic textures. Some basalts of similar compositions experienced retrograde(?) prehnite-pumpellyite facies metamorphism (Sharaskin, this volume).

Despite the evidently high grades of metamorphism and the probability that the metabasalts were metamorphosed prior to emplacement in the breccias, much of the metamorphism was hydrothermal and occurred after the breccias were deposited. The alteration is concentrated in two zones lower in the breccias (Fig. 2). Its effect was to form chlorite-actinolite aggregates in some rocks and to riddle many of them with chlorite veins. The breccia matrix, which originally consisted of crushed angular fragments and chips from the larger clasts, has been intensely altered, especially in the two zones just mentioned. Mafic minerals throughout most of the upper breccia matrix (originally olivine, diopside, amphibole, and biotite) are now largely or entirely altered to serpentine, talc(?) chlorite, and abundant reddish iron hydroxides. In the zones of intense alteration, the matrix is green, not red, in color and is almost completely chloritized. One effect of chlorite formation has been to redistribute potassium, which does not enter the chlorite crystal lattice. It was originally fairly abundant in such minerals as amphibole and biotite in the breccia matrix and in the more evolved rock types (andesite, dacite) in the lower breccias. Additional potassium probably was provided by seawater. The potassium now occurs in almost pure potassium feldspar in the chloritized breccias, replacing calcic plagioclases around the edges of coarse gabbro cobbles and completely replacing many plagioclase chips in the matrix, giving them a bleached appearance. In the zone of intense alteration in the upper breccia (Cores 55 and 56, Fig. 2), this alteration has completely demagnetized the gabbros (Bleil, this volume). Both the formation of chlorite and the exceeding of Curie temperatures of the gabbros imply quite elevated temperatures of hydrothermal alteration. Oxygen isotope data obtained on drusy quartz in the topmost piece of breccia recovered, and on potassium feldspars, indicate temperatures of formation of these minerals of about $100^{\circ} \mathrm{C}$ near the top of the breccias and $200^{\circ} \mathrm{C}$ in the highly chloritized zone (Lawrence and Natland, this volume). The association of chlorite with epidote suggests that temperatures locally exceeded $250^{\circ} \mathrm{C}$, based on analogy with marine geothermal systems (e.g., Humphris and Thompson, 1978; Mottl and Holland, 1978) and Iceland (Tomasson and Kristmannsdottir, 1972). The occurrence of minerals such as prehnite, actinolite, chlorite, and biotite suggests that temperatures may even have reached $350^{\circ} \mathrm{C}$, based on comparisons with 
the Cerro Prieto and Salton Sea geothermal systems (Elders et al., 1979; McDowell and Elders, 1980). These greenschist facies assemblages did not necessarily form at elevated pressures, as the Salton Sea and Cerro Prieto occurrences demonstrate. Those gabbros with aluminous amphibole and green spinel apparently indicate elevated pressures (Natland, gabbros chapter, this volume), but these minerals clearly formed before the breccias were emplaced and hydrothermal alteration occurred.

Some alteration, but not at quite these temperatures, may be occurring today. A heat flow of 2.1 heat flow units (HFU), or $88 \mathrm{~mW} / \mathrm{m}^{2}$, was measured in Hole 453 (Uyeda and Horai, this volume). This extrapolates to temperatures at the top of the breccias of about $50^{\circ}$. Moreover, sediment pore fluids show sharp reversals of $\mathrm{Mg}^{2+}$ and $\mathrm{Ca}^{2+}$ just above the breccias to near seawater compositions. Gieskes and Johnson (this volume) infer from this that little-modified seawater must be flowing beneath the sediments at the top of the still-permeable breccias, driven by hydrothermal convection. These must have flushed out pore fluids produced during extensive chloritization of the breccias, which should have had compositions considerably different from seawater (i.e., lower $\mathrm{Mg}^{2+}$ and higher $\mathrm{Ca}^{2+}$ ).

These various types of metamorphism and alteration modified the compositions of the volcanic rocks and gabbros in the breccias. The most important effects are removal of $\mathrm{CaO}$ and probable addition of $\mathrm{MgO}$ during higher grades of metamorphism and addition of $\mathrm{K}, \mathrm{Rb}$, and $\mathrm{Ba}$ during chloritization of the breccia matrix and transformation of plagioclases to K-feldspar. These effects result in a higher proportion of normative albite, lower normative hypersthene (or more olivine), and higher normative orthoclase, respectively, than in little altered basalts of similar composition recovered at DSDP Site 451 , on the West Mariana Ridge, $44 \mathrm{~km}$ away (Natland, gabbros chapter, this volume). The hydrothermally altered metaandesites and dacites of the lower breccia have been almost entirely albitized compared with fresh andesites and dacites from the Mariana arc system.

Despite these alteration effects, the original gabbros and volcanic rocks now in the breccias are undeniably calc-alkalic (Wood et al., this volume). Alteration has not removed the signature of fairly low iron enrichment that characterizes calc-alkalic suites, and, more important, much of the calc-alkalic trace element chemistry of the rocks is intact. Elevated abundances of $\mathrm{Sr}$ and light rare-earth elements show them to be kindred to little-altered calc-alkalic rocks from the Mariana arc (Dixon and Batiza, 1979) and the West Mariana Ridge (Mattey et al., 1980; Wood et al., 1980).

The gabbros have a remarkable and surprisingly restricted range of compositions expressed in terms of "cryptic variation" parameters such as $\mathrm{Mg} / \mathrm{Mg}+\mathrm{Fe}$ and normative $\mathrm{An} / \mathrm{Ab}+\mathrm{An}$. Of 31 gabbro samples analysed from this site, all but 4 have normative $\mathrm{An} /$ $(\mathrm{An}+\mathrm{Ab})>0.75$, and in many this ratio exceeds 0.90 (Fig. 3A). Most conform petrographically to olivine gabbro, but with widely varying modal proportions of plagioclase and clinopyroxene. A few gabbro samples are olivine-free and consist of clinopyroxene, plagioclase, biotite, magnetite, and ilmenite or of amphibole and plagioclase, with minor opaques. Most of the samples have heteradcumulus textures, but others have been recrystallized and are now granoblastic. The plagioclase in olivine gabbros is extremely calcic, and anorthite $\left(\mathrm{An}_{94-97}\right)$ in composition. Olivines are fairly iron-rich $\left(\mathrm{Fo}_{72-76}\right)$, clinopyroxenes are diopsidic to salitic, and amphiboles are hornblendic except in the metamorphosed gabbros (Natland, gabbros chapter, this volume). The metagabbros with green hercynitic spinel are few and are compositionally similar to the olivine gabbros. Their spinel and aluminous amphiboles appear to represent a subsolidus reaction between olivine and plagioclase in the presence of water.

The calcic plagioclase and high normative anorthite contents of the whole-rock analyses distinguish these gabbros from gabbros in fracture zones, in ophiolites, and in stratiform complexes such as the Bushveld or Skaergaard (Fig. 3A). They most resemble gabbros occurring as ejected blocks from Soufrière volcano, St. Vincent, West Indies (Lewis, 1973; Arculus and Wills, 1980); as zoned fragments of plutons tectonically emplaced at high levels among granodioritic and quartzdioritic plutons of the Peninsular Range batholith in Southern California (Nishimori, 1976); and as xenoliths in lavas from Agrigan volcano in the Mariana Arc (Stern, 1979), all calc-alkalic associations. The average composition of the gabbros at Site 453 is nearly identical to the composition of a cumulus gabbro mass calculated by Stern to underlie Agrigan and to be responsible for its calc-alkalic trend (Fig. 3B).

To explain the compositions and mineralogy of the similar Peninsular Range gabbros, Nishimori (1976) argued that $p\left(\mathrm{H}_{2} \mathrm{O}\right)$ of up to 2 kbar caused the liquidus to shift to more calcic plagioclase compositions (following arguments of Yoder and Tilley, 1962; and Yoder, 1969). Fractionation of mineral assemblages with a high proportion of such calcic plagioclase (which has only about $43 \% \mathrm{SiO}_{2}$ ) would cause rapid $\mathrm{SiO}_{2}$ enrichment in residual liquids before there could be much iron enrichment. Such fractionation involving removal of material equivalent to the Site 453 gabbros could explain the calcalkalic variation of West Mariana Ridge lavas cored at Site 451, $44 \mathrm{~km}$ to the west (Mattey et al., 1980).

The gabbros are proof of the sundering of an island arc during back-arc spreading. They also indicate that a portion of this Miocene arc must occur on the eastern side of the Mariana Trough-which is evident from coeval volcanic exposures on Guam (Stark, 1963). If the high grades of greenschist facies metamorphism-particularly the formation of aluminous amphibole and green spinel-manifest in the gabbros and metabasalts indicate elevated pressures, then considerable uplift (perhaps $10 \mathrm{~km}$ or more) attended rifting. This seems excessive in the context of simple rifting. A hydrothermal origin for the metamorphic minerals eases this problem considerably. Still, some uplift must have occurred to have caused the exposure of gabbros which crystallized at elevated $p\left(\mathrm{H}_{2} \mathrm{O}\right)$. There is at present about $4.5 \mathrm{~km}$ of relief on the West Mariana Ridge, more than half the to- 


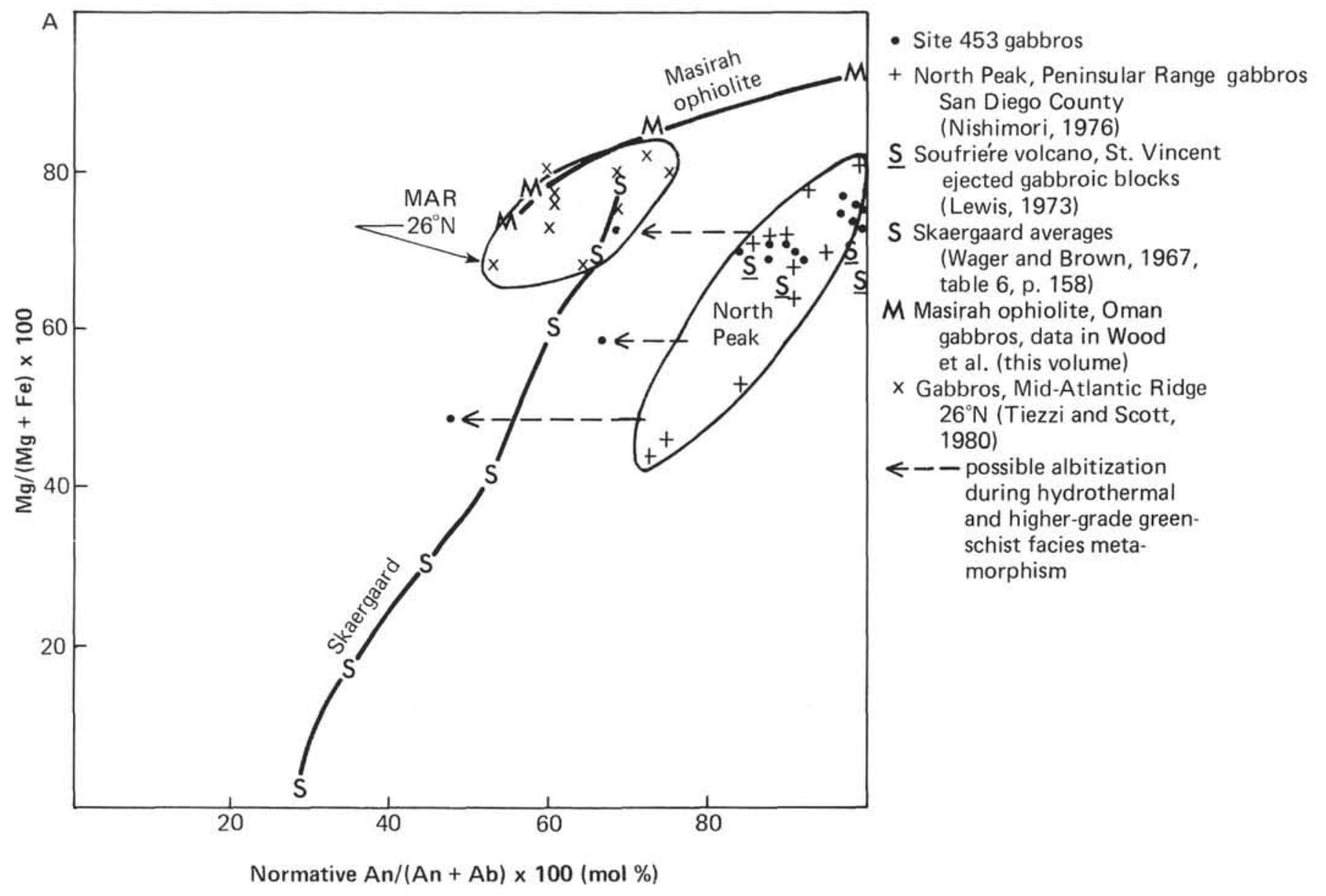

Figure 3. $\mathrm{A} . \mathrm{Mg} /(\mathrm{Mg}+\mathrm{Fe}) \times 100$ versus normative $\mathrm{An} /(\mathrm{An}+\mathrm{Ab}) \times 100$ for calc-alkalic gabbros compared with ocean crust, ophiolitic, and layered gabbro intrusions. B. $\mathrm{Mg} /(\mathrm{Mg}+\mathrm{Fe}) \times 100$ versus normative $\mathrm{An} /(\mathrm{An}+\mathrm{Ab}) \times 100$ for West Mariana Ridge and Agrigan Island, Mariana arc, compared with fields for Site 453 and Peninsular Range, southern California batholith (Nishimori, 1976), and the average cumulus mass beneath Agrigan calculated by Stern (1979) to be responsible for the Agrigan fractionation trend (solid line). The effect of albitization on Hole 453 lower breccia metavolcanic samples is indicated by dashed arrows.

total amount of combined exhumation and uplift needed to expose gabbros which crystallized at $p\left(\mathrm{H}_{2} \mathrm{O}\right) \simeq p$ (total) of about 2 kbar.

The nearest sources for the breccias are the walls of the sediment pond in which Site 453 was cored. The closest and most likely source is a small promontory or spur to the northwest which appears to link directly with the West Mariana Ridge (Packham and Williams, this volume). Based primarily on the flatness of the breccia surface in the sediment pond as seen in airgun profiles (Site 453 chapter, this volume), Natland (gabbros chapter, this volume) and Sharaskin (this volume) believe that the breccias most closely resemble deposits of catastrophic rock falls or "stürtzstroms" (Hsü, 1975). Alternatively, "fans" of mass-wasted volcanic and plutonic rocks with slopes as little as $2^{\circ}$ have been seen in large North Atlantic transform-fault zones (P. J. Fox, personal communication). The process of breccia emplacement at Site 453, then, need not have been catastrophic. The breccia formation process ceased completely sometime prior to $5.0-5.2 \mathrm{Ma}$, the time of formation of the oldest paleontologically dated turbidite at Site 453 (Ellis, this volume).
In summary, the occurrence of polymict breccias at Site 453 is the result of two fundamentally different thermal-tectonic events. The rocks represent both the extrusive and intrusive products of calc-alkalic crystal fractionation at elevated water pressure. The exposure of these rocks and their chaotic dismemberment into breccias was caused by back-arc basin rifting prior to 4.5 Ma. The rifting apparently reached the very heart of the arc, reaching solidified magma chambers deep within it. The hydrothermal alteration of portions of the breccias is clearly related to geothermal activity in the Mariana Trough. Whether this was caused by magmatic injection beneath Site 453 cannot be confirmed by present data, although the high temperatures of hydrothermal alteration probably indicate a magmatic source of heat nearby.

\section{Interarc Basin Basalts at Sites $\mathbf{4 5 4}$ and $\mathbf{4 5 6}$}

The lithology, distribution of chemical types, and location of changes in magnetic inclinations downhole are shown in Figure 4 for the three holes penetrating basalts at Sites 454 and 456 , located on either side of, yet close to the center of spreading in, the Mariana Trough. The 


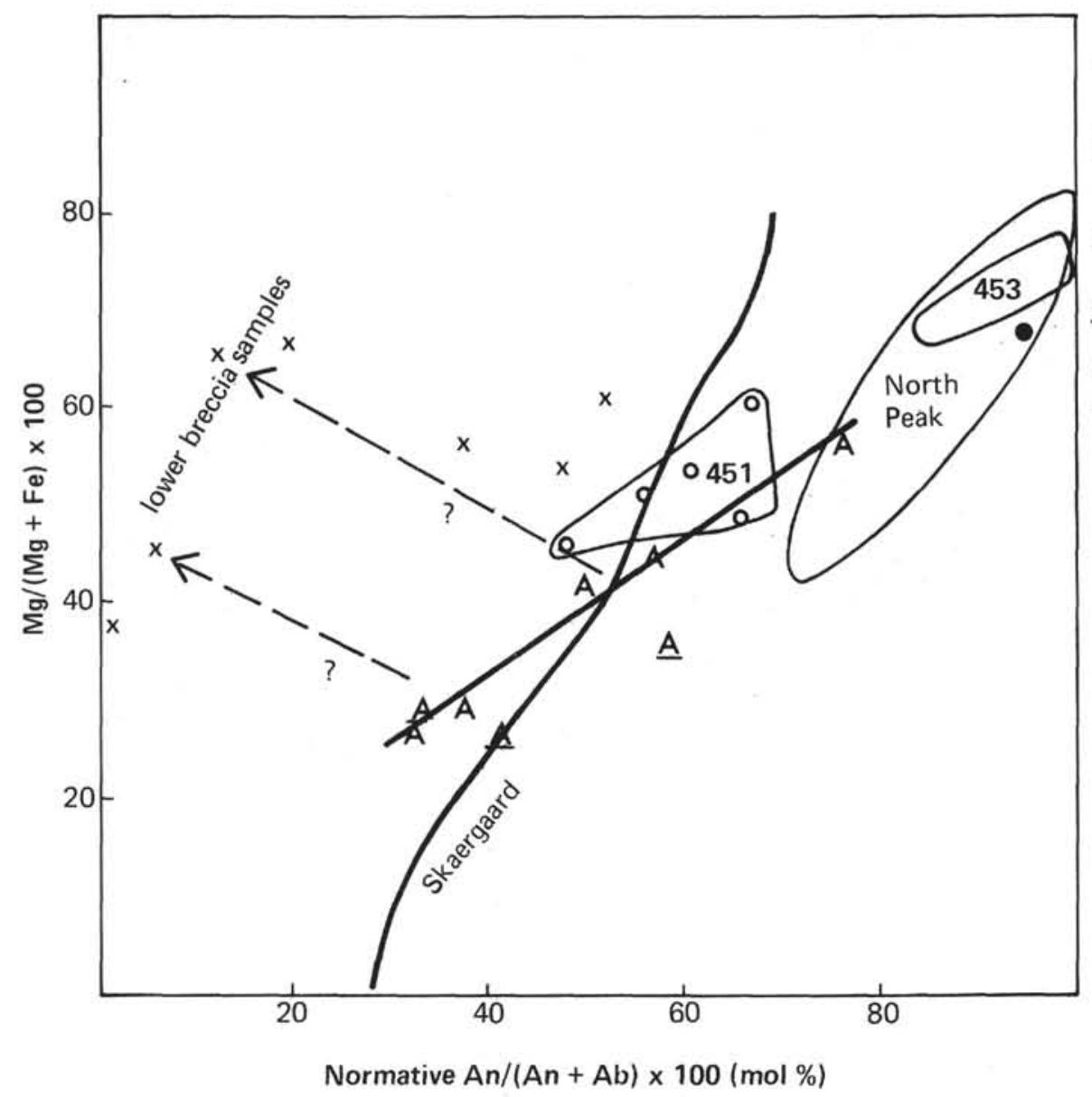

x Site 453 metavolcanic rocks

- Site 451 West Mariana Ridge volcanic clasts (Mattey et al., 1980)

A Agrigan volcano lavas (Stern, 1979)

A Agrigan volcano lavas (Dixon and Batiza, 1979)

- Average cumulus mass

- beneath Agrigan (Stern, 1979)

$\checkmark$ possible albitization and chloritization during hydrothermal alteration and greenschist facies metamorphism. Arrows are traced back to unaltered Agrigan lavas with similar $\mathrm{SiO}_{2}$.

Gabbro fields, Skaergaard trend as on Figure 3.

Solid line is least-squares fit to Agrigan lavas using data of Stern (1979). $r^{2}=0.9867$

Figure 3. (Continued).
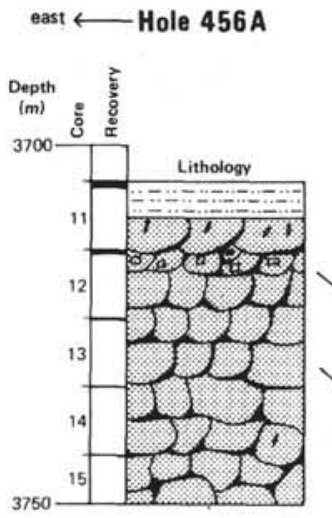

Hole 456

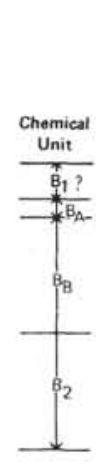

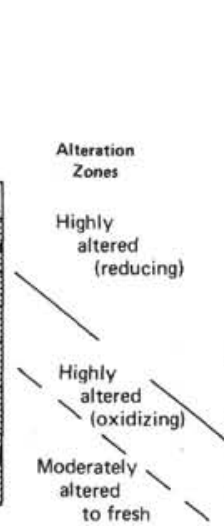

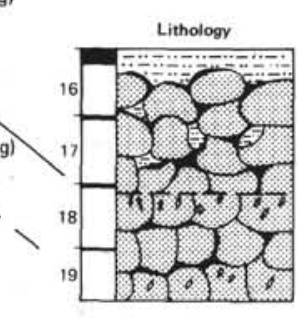

$\sim 200 \mathrm{~m}$ apart
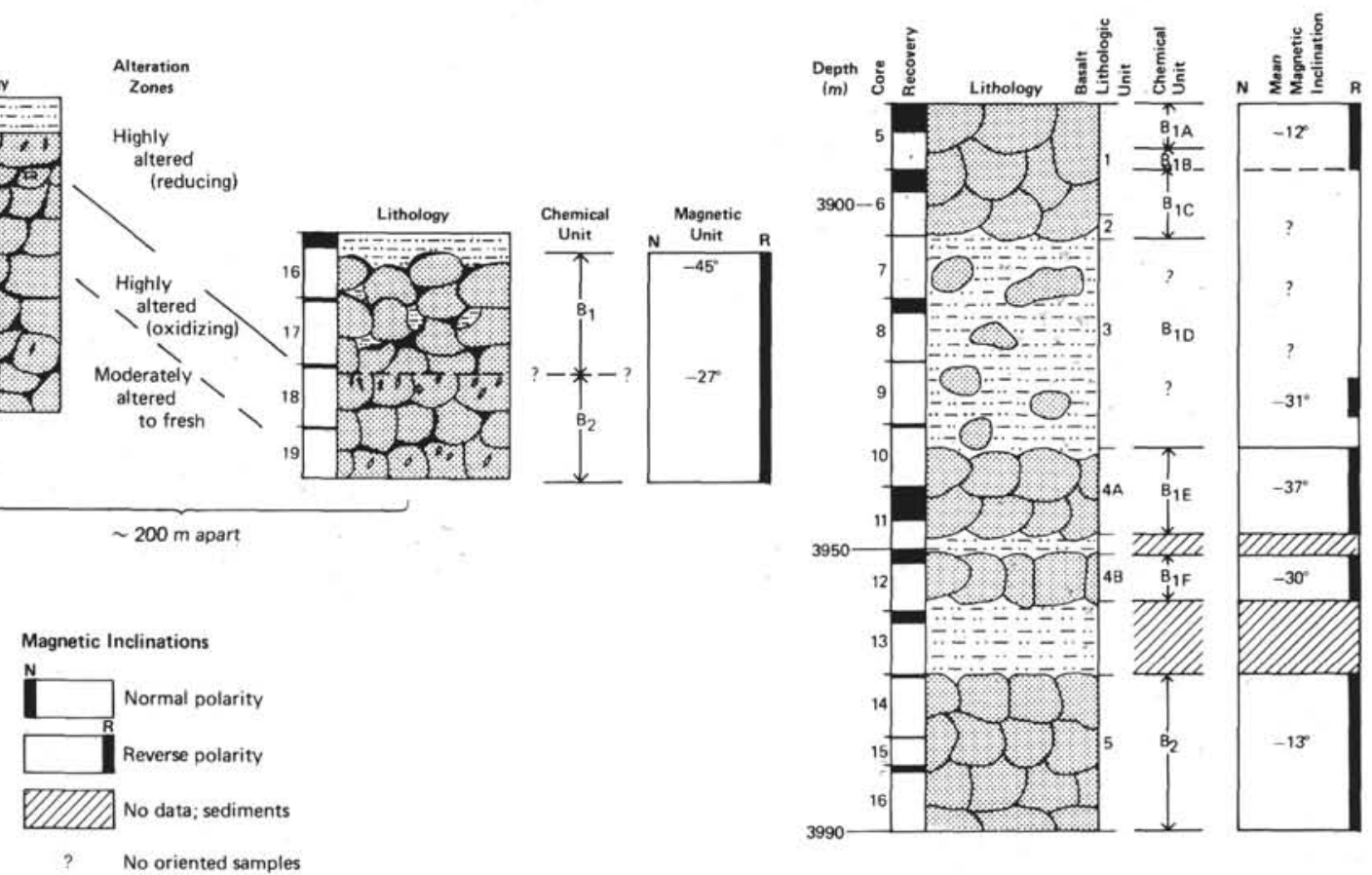

Figure 4. Basement lithologic, chemical, and magnetic stratigraphy, Sites 454 and 456, Mariana Trough. 
oldest sediments at Site 454 are about $1.6 \mathrm{~m} . \mathrm{y}$. old and at Site 456 are $1.8 \mathrm{~m}$.y. old (Kling, this volume; Ellis, this volume). The basalts at Site 454 are interbedded with vitric mud. The two holes at Site 456 are about 200 meters apart and there are no interbedded sediments. However, one basalt piece in Hole 456 has a recrystallized sedimentary inclusion several centimeters in diameter. The basalts of both sites are mostly sparsely phyric or microphyric vesicular pillows and flows, moderately to highly olivine-rich. Only one basalt type in Hole $456 \mathrm{~A}$ was strongly plagioclase and olivine phyric (Fig. 4). The basalts are quite vesicular, although great depth of eruption $(\sim 3500 \mathrm{~m})$ has undoubtedly kept the size of vesicles quite small. The upper massive flow in the middle of the basement section at Site 454 is more vesicular, hence less dense, toward the top, a feature readily revealed by the density logs (Fig. 5). At Site 456, many vesicles are filled with secondary minerals, including quartz, calcite, and pyrite, giving the rocks higher than usual thermal conductivities (Horai, this volume). The greater abundance of vesicles in these basalts than in normal mid-ocean-ridge basalts (MORB) is suggestive of a higher primary volatile content (cf. Garcia et al., 1979; Muenow et al., 1980), though this is not necessarily typical of all interarc basin basalts.

Several chemical types occur at Sites 454 and 456, identified by the letter B (for basalt) and an alphabetical or numerical subscript on Figure 4. The various types of basalt can be distinguished by trace element variation, such as that of $\mathrm{Ni}$ versus $\mathrm{Zr}$ (Fig. 6). Those chemical types present in Hole 456A but not Hole 456 are given alphabetical subscripts. The basalts have the major element characteristics of little-fractionated or moderately fractionated mid-ocean-ridge basalts (i.e., $\mathrm{TiO}_{2} \simeq 1.0 \%$; $\left.\mathrm{K}_{2} \mathrm{O} \simeq 0.3 \% ; \mathrm{Mg} / \mathrm{Mg}+\mathrm{Fe}=0.6-0.7\right)$. Despite this, only a few of them have the geochemical characteristics of depleted normal (N-type) MORB. Wood et al. (this volume) note in particular "higher $\mathrm{Sr}, \mathrm{Ba}, \mathrm{Th}$, and light REE contents relative to $\mathrm{Zr}, \mathrm{Ti}, \mathrm{Y}$, and the heavy REE than N-type MORB.' They also are depleted in Ta and

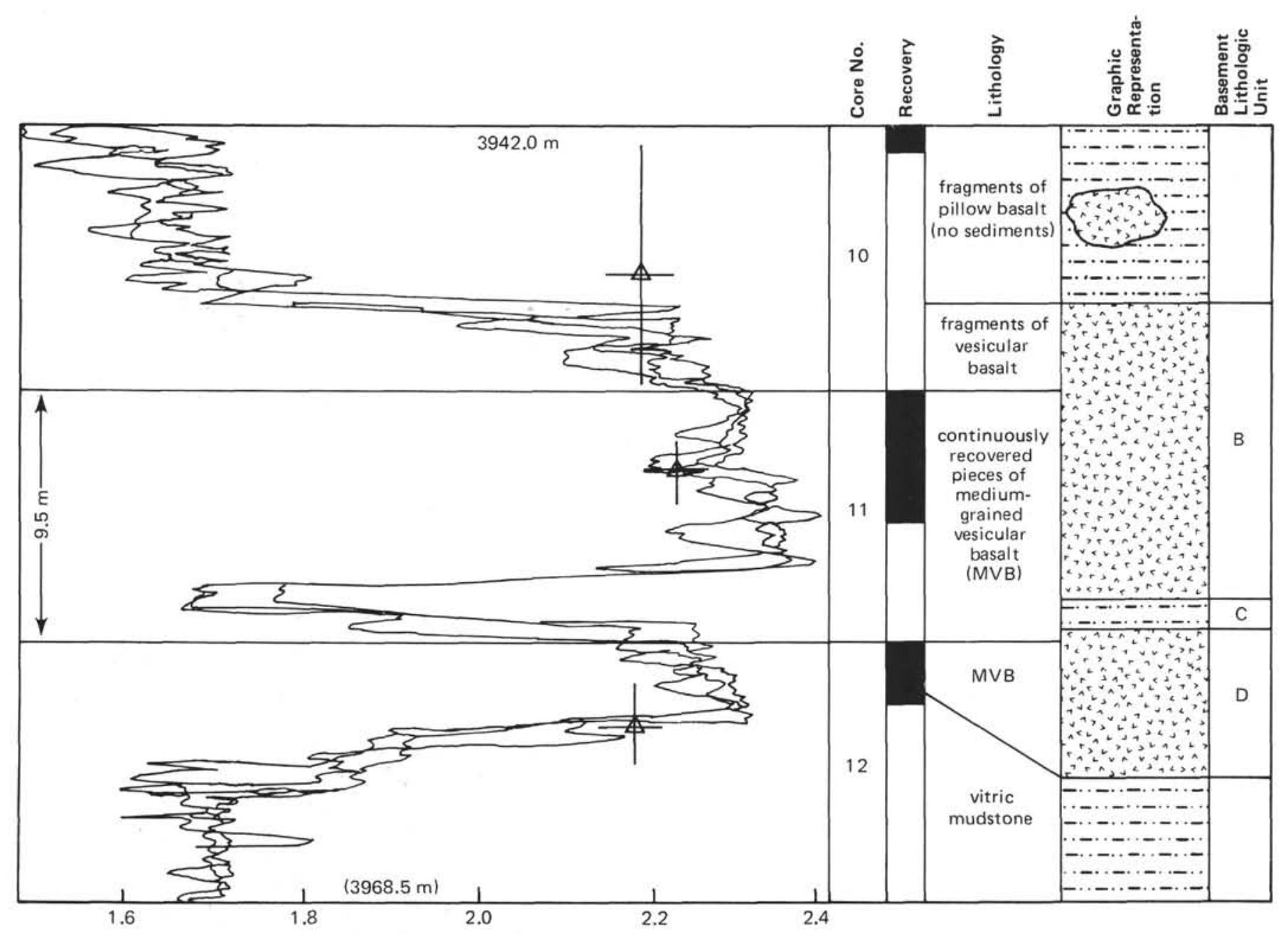

Figure 5. A portion of the three density logs (overlapped) obtained in Hole 454A (Mariana Trough) during Leg 60, showing the inferred relationship to interbedded massive basalts, pillow basalts, and sediments. Core number, recovery, and lithologic units are also shown.Triangles with error bars indicate locations of samples and shipboard density measurements obtained on them by T. Francis. Note decrease in density upward in upper massive basalt, caused by vesicles. 


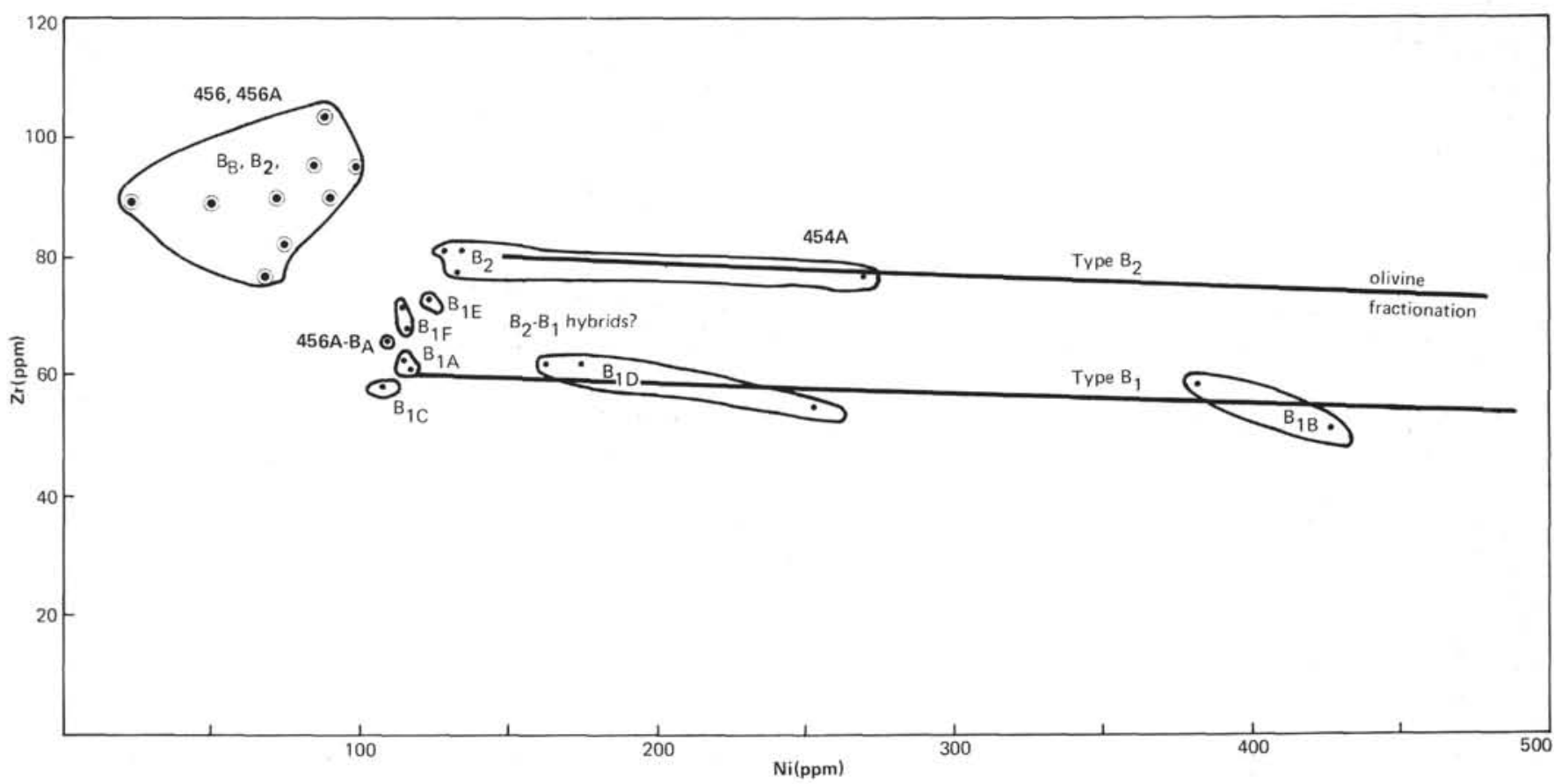

Figure 6. Ni versus $\mathrm{Zr}$ for basalts of Holes 454A, 456, and 456A, Mariana Trough. $(\bullet=$ Hole 454A; $\odot=$ Holes 456 and $456 \mathrm{~A}$. Chemical types and subtypes of Figure 4 are indicated. Data from Wood et al., this volume.) In Hole $454 \mathrm{~A}$, olivine-controlled Type $\mathrm{B}_{2}$ was succeeded by olivinecontrolled $B_{1}$ subtypes with systematically lower $\mathrm{Zr}$. Subtypes $\mathrm{B}_{1 \mathrm{E}}$ and $\mathrm{B}_{1 \mathrm{~F}}$, which stratigraphically represent the earliest $\mathrm{B}_{1}$ subtypes, have intermediate $\mathrm{Zr}$, suggesting that they may be hybrids. Ni concentrations in any given sample are probably controlled by local accumulations of olivine in pillows and flows. Holes 456 and $456 \mathrm{~A}$ samples are more fractionated than those from Hole $454 \mathrm{~A}$; Ni abundance probably was affected by alteration.

$\mathrm{Nb}$ relative to $\mathrm{Th}$ and $\mathrm{La}$. This geochemical signature is characteristic of island arc basalts (Saunders et al., 1980). Such features seem to be gradational throughout the basalts of Hole 454A and occur in one unit (the plagioclase-olivine strongly phyric basalt type $\mathrm{B}_{\mathrm{A}}$ ) of Hole $456 \mathrm{~A}$. Wood et al. (this volume) argue that this could represent mixing of depleted N-type MORB with island arc magmas at Site 454 and interbedding of the two magma types at Site 456. It could also reflect modification of the mantle source by fluids carrying large-ion lithophile (LIL) elements which were derived from dehydration of the subducted slab or from sediments carried down the subduction zone. Alternatively, the anomalous chemistry might be produced by assimilation of the intimately associated glass-rich sediments, derived from the Mariana arc, and which would have the required "arc" component. However, the fact that similar geochemical features are apparent in other marginal basin basalts, at least during the early stages of back-arc spreading (Tarney et al., 1981), lends support to the suggestion that the cause is more fundamental and related to modification of the mantle source composition prior to back-arc spreading.

There is good trace element evidence that the various chemical types are not related by crystal fractionation before or after possible contamination. As an example, substantially higher $\mathrm{Zr}$ levels occur in basalt type $\mathrm{B}_{2}$ at Site 454 than in basalt type $B_{A}$, despite similar ranges of $\mathrm{Ni}$ (Fig. 6). Ni abundance in these samples is controlled primarily by olivine fractionation, which produces the parallel trends on Figure 6. The trends are an indication that a range of parental compositions are produced either by variable degrees of melting or by differences in the abundances of low-partition-coefficient (hygromagmatophile, or HYG) elements in the mantle source of these basalts. Such variations resemble those along certain portions of the Mid-Atlantic Ridge (e.g., DSDP Sites 332 and 395; Natland, 1978; Sites 409-413, Tarney et al., 1979).

Fryer et al. (this volume) argue that basaltic glasses from Sites 454 and 456 , as well as those from dredge hauls from the central axis of the Mariana Trough, resemble other interarc basin basalts, particularly those of the Scotia Sea (e.g., Saunders and Tarney, 1979), but differ significantly in major element composition from normal MORB. The features they single out are (1) generally lower $\mathrm{TiO}_{2}$, (2) generally higher $\mathrm{Na}_{2} \mathrm{O}$, (3) lower $\mathrm{FeO}^{*}$ (total iron as $\mathrm{FeO}$ ), and (4) higher $\mathrm{Al}_{2} \mathrm{O}_{3}$ when specified at a given $\mathrm{MgO}$ content. They also note some of the trace element differences cited by Wood et al. (this volume), somewhat higher ${ }^{87} \mathrm{Sr} /{ }^{86} \mathrm{Sr}$ (Hart et al., 1972 ) as well as more $\mathrm{H}_{2} \mathrm{O}$-rich volatile inclusions (Garcia et al., 1979) than in MORB.

Alteration at Site 454 was at low temperatures and oxidative, producing brown or reddish alteration rinds on some basalts but generally having little effect on major oxide chemistry. At Site 456, however, alteration was both extensive and diverse, resulting in marked changes in the bulk compositions of the basalts. In both Holes 456 and 456A, at the top of basement, alteration was nonoxidative and occurred at high temperature, resulting in the large-scale development of chlorite in the 
basalts and of pyrite, opal, quartz, and chalcopyrite (Natland and Hekinian, this volume). Recrystallized tuffs just above basalt contain quartz and wairakite, which typically forms under high temperature hydrothermal conditions in silica-rich materials and has been produced experimentally only above $250^{\circ} \mathrm{C}$ (Liou, 1971).

Below the chloritic, pyritized basalts, over a vertical distance of only a few meters, alteration becomes distinctly oxidative in both holes, with extensive development of reddish alteration rinds and of soft, friable, clay-rich basalts. At the bottom of each hole, even this alteration disappears and fresh glass occurs.

The chemical effects of the alteration contrast in the nonoxidative and oxidative zones. In the nonoxidative zone, there is considerable variation in $\mathrm{CaO}$ and $\mathrm{MgO}$ among basalts within distinct chemical types (defined on the basis of immobile oxides such as $\mathrm{TiO}_{2}$ and trace elements such as $\mathrm{Zr}$ ). Yet there is virtually no variation in very low abundances of $\mathrm{K}_{2} \mathrm{O}$. In the zones of oxidative alteration, however, $\mathrm{K}_{2} \mathrm{O}, \mathrm{Rb}$, and $\mathrm{Ba}$ vary considerably from sample to sample, evidently reflecting the formation of abundant $\mathrm{K}-\mathrm{Fe}$ clay minerals in the samples.

The simple downhole sequence of nonoxidative and oxidative zones of alteration followed by fresh basalts suggests that one episode of alteration was involved in which high-temperature nonoxidative hydrothermal fluids made their way along the permeable sediment/basalt contact (Natland and Hekinian, this volume). The zone of oxidative alteration was a zone of intense mixing with oxygenated pore fluids (essentially seawater). K, Rb, or Ba leached from basement rocks and carried by the high-temperature fluids did not enter the chlorite crystal lattices forming in the nonoxidative zone, but continued flux and mixing of such fluids with seawater in the oxidative zone favored formation of $\mathrm{K}$ - and Fe-rich clay minerals. Below the mixing zone, neither the temperature of the fluids nor their diluted composition produced significant alteration.

\section{Fore-arc and Trench Drilling}

The objective of drilling in the fore-arc region and the trench was to determine if fragments of ocean crust have been emplaced by faulting into the landward wall of the Mariana Trench. The principal result of this drilling was to establish quite the contrary. In two holes in the fore-arc region, 458 and $459 \mathrm{~B}$, extrusive igneous basement was reached beneath arc-produced Eocenelate Oligocene turbidites. In Hole 458, the lavas include an unusual rock type, boninite, known elsewhere only from island arc settings and certain ophiolites. These are interbedded with island arc tholeiites, which also were recovered in Hole 459B. Although there were drilling difficulties in igneous and metamorphic talus in four holes at two sites in the trench $(460,460 \mathrm{~A}, 461$, and $461 \mathrm{~A}$ ), those rocks, too, have primarily the compositions of island arc tholeiites and in Hole 460 include a boninite. No ocean crust or marine pelagic sediments were cored in any of these holes.

The following sections provide an evaluation of lava stratigraphy in Holes 458 and $459 \mathrm{~B}$ and a summary of the principal hypotheses presented in this volume concerning the origin of the fore-arc lavas and structure. Operational summaries and detailed lithologic and petrographic descriptions are in the site chapters.

\section{Igneous Rock Series in the Fore-arc and Trench Region}

The boninitic rocks of Hole 458 are the first such lavas ever recovered by drilling. Although boninites are unusual, they have chemical and petrographic characteristics that are of great importance to the understanding of island arc magmatism. The boninites of Hole 458 are of particular importance because island arc tholeiites occur in the same hole and because we can specify that they erupted in late Eocene-early Oligocene times, early in the history of the Mariana arc. Outside this volume, the Hole 458 boninites have already been repeatedly cited with reference to the earliest stages of arc magmatism (Cameron et al., 1979, 1980; Beccaluva et al., 1980; Meijer, 1980) and because of their relevance to ophiolites (Cameron et al., 1979, 1980). Here, we focus on the stratigraphy of the boninites and arc tholeiites of Hole 458 and 459B and consider possible geochemical relationships among the rock types. Other chapters in this volume may be consulted for details of petrography and mineralogy (Meijer et al. and Natland, crystal morphologies chapter), geochemistry (Wood et al., Bougault et al., and Hickey and Frey), and experimental petrology (Kushiro).

The chemical and magnetic stratigraphy of volcanic basement in Holes 458 and 459B is shown in Figure 7. In both holes, the rocks consist of alternating pillows and more massive flows or possibly intrusives. In each hole, several distinctive chemical and magnetic units were identified. Chemical units are defined on the basis of one or more essentially identical, or at least very similar, chemical analyses in stratigraphic order, based mainly on the data of Wood et al. (this volume). In making comparisons, alteration, which affected mainly such mobile elements as $\mathrm{K}, \mathrm{Rb}$, and $\mathrm{Ba}$, was taken into account by keying the stratigraphy to less mobile elements such as Ti, Zr, Y, and the like. Also discounted were the effects of possible in situ magmatic differentiation, which has occurred in some of the more massiye cooling units. Using the data of Wood et al. (this volume), average analyses of the four principal chemical types in Hole 458 (plus comparative individual and average analyses) and seven chemical subtypes in Hole 459B are listed together with trace element averages and CIPW norms in Table 2. There are two principal rock types, designated $\mathrm{A}$ and $\mathrm{B}$, referring respectively to boninitic lavas and basalts. The distinct chemical types and subtypes are designated by numerical and alphabetical subscripts on Figure 7.

The boninitic rocks of Hole 458 have been variously referred to in this volume as members of the boninite series (Meijer et al.; Sharaskin), as high-MgO bronzite andesites (Site 458 chapter), or more simply as boninites and bronzite andesites (Natland, crystal morphologies chapter). This lack of consistent nomenclature is a consequence of petrographic dissimilarities between the Hole 458 lavas and certain previously described boninites as 


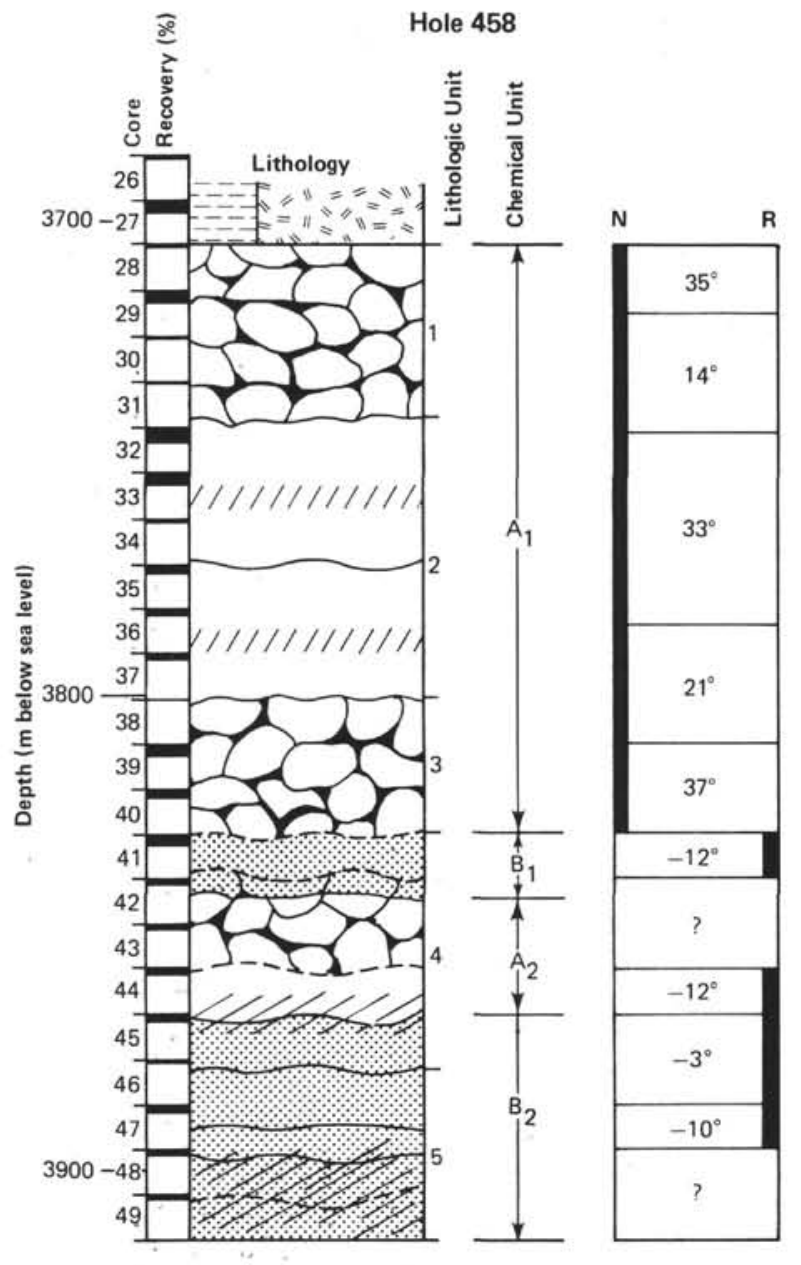

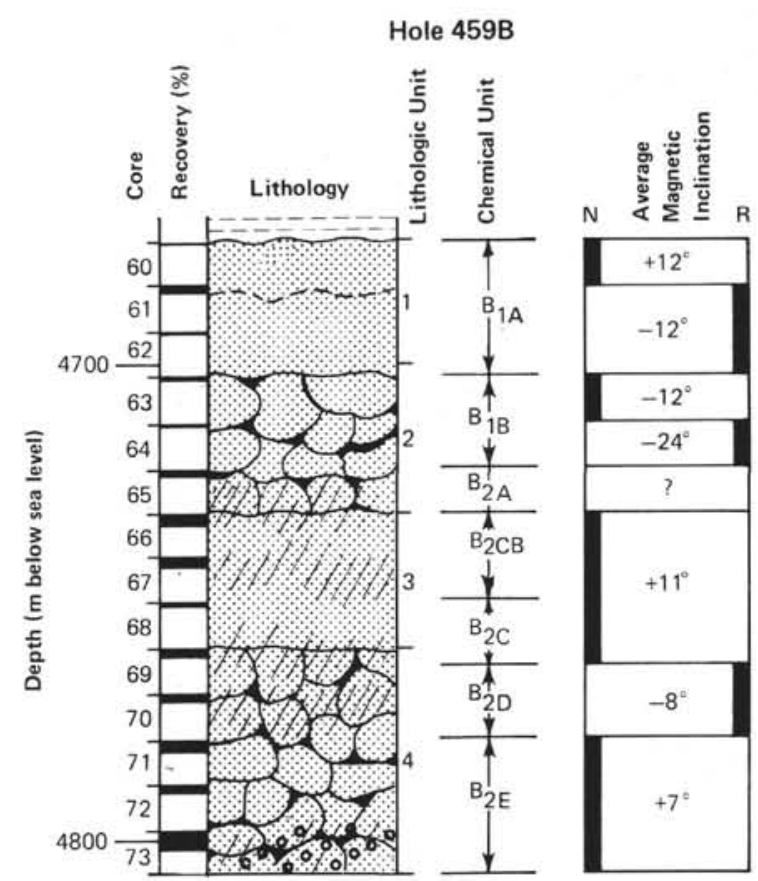
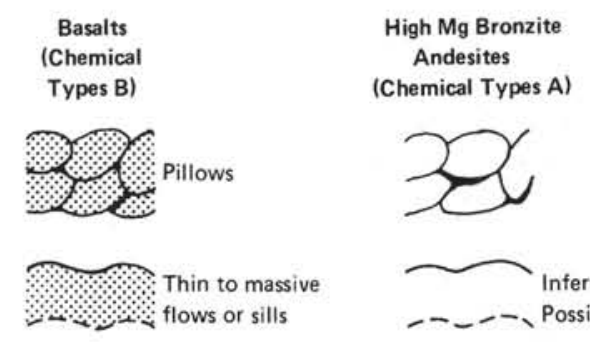

Chemical Types A
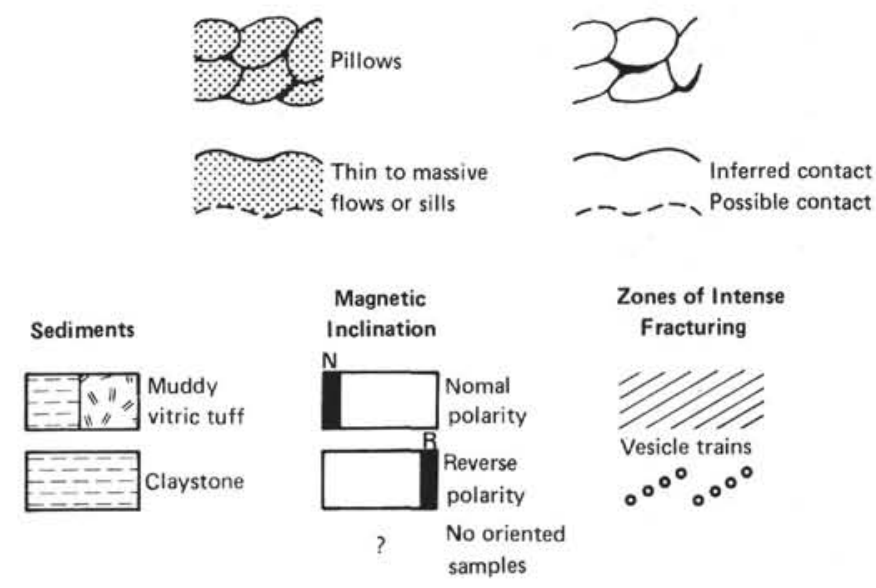

Figure 7. Basement lithologic, chemical, and magnetic stratigraphy, Holes 458 and 459B, Mariana fore-arc region, drilled during Leg 60.

well as of generally lower $\mathrm{MgO}, \mathrm{Ni}$, and $\mathrm{Cr}$ in Hole 458 samples. For these reasons, Meijer (1980) defines normative criteria to distinguish boninite series lavas from more typical andesites and from basalts. He is critical of early petrographic schemes. Natland (crystal morphologies chapter, this volume) noted that glassy boninites, on which the original petrographic definitions are based, represent only thin outer chilled rims of boninite pillows, and questioned the applicability of the designation "high-MgO" to many of the Hole 458 boninitic lavas. He proposed extending the petrographic definition of boninites to include pillow interiors and massive flows in which plagioclase can be an abundant mineral and, for the purposes of classification, distinguished olivine boninites from simple boninites that lack olivine, such as the Hole 458 lavas. The lower $\mathrm{MgO}$ Hole 458 samples can thus be termed bronzite andesite and included in a boninite series (Bloomer et al., 1979). For convenience we shall use these conventions in the following discussion.

The distinctive petrographic feature of all boninites is crystallization of groundmass microlitic clinopyroxene before plagioclase, even in fairly coarse-grained pillow interiors. The Hole 458 lavas also contain complex bronzite-augite intergrowths in glassy and spherulitic samples, plus separate phenocrysts of both minerals. Temperatures of crystallization of these minerals, calculated using the formula of Ishii (1980), are in the range of $1250^{\circ} \pm 60^{\circ} \mathrm{C}$, higher than two-pyroxene tholeiitic island arc basalts and calc-alkalic andesites from the 
Table 2. Averages of chemical types and subtypes of boninites and island arc tholeiites, DSDP Hole 458 and $459 \mathrm{~B} .{ }^{\mathrm{a}}$

\begin{tabular}{|c|c|c|c|c|c|c|c|c|c|c|c|c|c|c|c|}
\hline & & \multicolumn{7}{|c|}{ Hole 458} & \multicolumn{7}{|c|}{ Hole 459B } \\
\hline & & $\begin{array}{c}\text { Ave. } \\
\text { Type } A_{1} \\
\text { Boninite } \\
1(21)^{\mathrm{b}}\end{array}$ & $\begin{array}{c}\text { Sample } \\
458-29-2 \text {, } \\
37 \mathrm{~cm} \\
\text { Boninite } \\
2\end{array}$ & $\begin{array}{c}\text { Ave. of } \\
\text { Bronzite } \\
\text { Andesite Flow } \\
\text { Cores } 32-35 \\
3(6)^{b}\end{array}$ & $\begin{array}{c}\text { Sample } \\
458-40-2 \text {, } \\
90 \mathrm{~cm} \\
\text { Boninite } \\
4\end{array}$ & $\begin{array}{c}\text { Type } \\
\text { B1 } \\
\text { Basalt } \\
5^{b}\end{array}$ & $\begin{array}{c}\text { Ave, } \\
\text { Type A } \\
\text { Boninite } \\
6(6)^{b}\end{array}$ & $\begin{array}{l}\text { Ave. } \\
\text { Type B2 } \\
\text { Basalt } \\
7(6)^{b}\end{array}$ & $\begin{array}{c}\text { Ave. } \\
\text { Type B } \mathrm{B}_{1 \mathrm{~A}} \\
\text { Basalt } \\
8(3)^{\mathrm{b}}\end{array}$ & $\begin{array}{c}\text { Ave. } \\
\text { Type BiB } \\
\text { Basalt } \\
9(2)^{b}\end{array}$ & $\begin{array}{c}\mathrm{B}_{2 \mathrm{~A}} \\
\text { Basalt } \\
10\end{array}$ & $\begin{array}{l}\text { Ave. } \\
\text { Type } B_{2 B} \text { B } \\
\text { Basalt } \\
11(3)^{b}\end{array}$ & $\begin{array}{c}\text { Ave. } \\
\text { Type B2C } \\
\text { Basalt } \\
12(2)^{b}\end{array}$ & $\begin{array}{c}\text { Ave. } \\
\text { Type B2D } \\
\text { Basalt } \\
13(2)^{b}\end{array}$ & $\begin{array}{c}\text { Ave. } \\
\text { Type B2E } \\
\text { Basalt } \\
14(4)^{b}\end{array}$ \\
\hline & $\mathrm{SiO}_{2}$ & 55.0 & 52.0 & 58.5 & 52.8 & 53.2 & 53.9 & 52.0 & 54.3 & 51.2 & 52.6 & 56.7 & 57.7 & 55.7 & 55.1 \\
\hline & $\mathrm{TiO}_{2}$ & 0.32 & 0.36 & 0.31 & 0.35 & 1.13 & 0.52 & 1.10 & 0.69 & 0.83 & 1.21 & 0.97 & 0.74 & 0.91 & 1.13 \\
\hline & $\mathrm{Al}_{2} \mathrm{O}_{3}$ & 15.2 & 14.4 & 14.2 & 14.9 & 15.5 & 14.3 & 14.0 & 14.6 & 14.3 & 13.9 & 13.1 & 13.3 & 14.3 & 13.9 \\
\hline & $\mathrm{Fe}_{2} \mathrm{O}$ & 9.31 & 10.23 & 9.12 & 10.24 & 9.66 & 10.54 & 13.63 & 9.95 & 10.67 & 13.63 & 11.89 & 10.82 & 11.01 & 11.91 \\
\hline & $\mathrm{MnO}^{3}$ & 0.12 & 0.12 & 0.11 & 0.09 & 0.06 & 0.13 & 0.11 & 0.14 & 0.14 & 0.16 & 0.15 & 0.12 & 0.11 & 0.11 \\
\hline & $\mathrm{MgO}$ & 6.87 & 9.71 & 5.62 & 8.97 & 3.73 & 6.21 & 6.69 & 5.78 & 9.64 & 6.07 & 5.09 & 5.52 & 5.40 & 5.19 \\
\hline & $\mathrm{CaO}$ & 9.59 & 8.70 & 9.79 & 7.98 & 6.12 & 8.33 & 6.55 & 10.82 & 8.47 & 6.06 & 7.25 & 7.63 & 8.25 & 7.40 \\
\hline & $\mathrm{Na}_{2} \mathrm{O}$ & 2.60 & 2.63 & 2.48 & 2.47 & 5.70 & 2.65 & 3.31 & 2.87 & 3.31 & 3.73 & 3.18 & 3.15 & 3.71 & 4.02 \\
\hline & $\mathrm{K}_{2} \mathrm{O}$ & 0.98 & 0.88 & 0.96 & 1.03 & 1.52 & 0.66 & 0.75 & 0.48 & 0.62 & 0.89 & 0.98 & 1.29 & 0.91 & 1.02 \\
\hline & $\mathrm{P}_{2} \mathrm{O}_{5}$ & 0.03 & 0.01 & 0.04 & 0.01 & 0.20 & 0.03 & 0.09 & 0.07 & 0.09 & 0.06 & 0.08 & 0.08 & 0.10 & 0.12 \\
\hline & Total & 100.02 & 99.01 & 101.13 & 98.86 & 96.82 & 97.27 & 98.23 & 99.70 & 99.27 & 98.35 & 99.39 & 100.35 & 100.40 & 99.90 \\
\hline & $\frac{\mathrm{Mg}}{\mathrm{Mg}+\mathrm{Fe}}$ & 0.594 & 0.653 & 0.550 & 0.634 & 0.433 & 0.558 & 0.493 & 0.535 & 0.641 & 0.462 & 0.459 & 0.502 & 0.493 & 0.463 \\
\hline \multicolumn{16}{|c|}{ Trace Elements (ppm) } \\
\hline & $\mathrm{Ni}$ & 76 & 76 & 61 & 97 & 11 & 74 & 29 & 56 & 60 & 24 & 23 & 29 & 26 & 14 \\
\hline & $\mathrm{Cr}$ & 212 & 216 & 185 & 290 & ii & 167 & 33 & 153 & 62 & 13 & 15 & 23 & 38 & 16 \\
\hline & $\mathrm{Sr}$ & 105 & 103 & 103 & 104 & 169 & 110 & 139 & 119 & 125 & 125 & 108 & 130 & 135 & 134 \\
\hline & $\mathrm{Zr}$ & 33 & 30 & 32 & 38 & 101 & 49 & 62 & 37 & 53 & 68 & 53 & 49 & 59 & 69 \\
\hline & $\mathrm{Y}$ & 3 & 2 & 8 & 6 & 31 & 15 & 24 & 15 & 29 & 27 & 23 & 19 & 26 & 32 \\
\hline & $\mathrm{Nb}$ & 2 & 3 & 5 & 7 & 7 & 4 & 5 & 4 & 6 & 6 & 2 & 3 & 4 & 5 \\
\hline \multicolumn{16}{|c|}{ CIPW Norms ${ }^{\mathrm{c}}$} \\
\hline & $Q$ & 4.31 & 0.00 & 10.86 & 0.82 & 0.00 & 6.25 & 0.91 & 4.49 & 0.00 & 0.52 & 8.56 & 8.06 & 3.54 & 2.19 \\
\hline & Or & 5.78 & 5.19 & 5.67 & 6.08 & 8.97 & 3.90 & 4.43 & 2.83 & 3.66 & 5.25 & 5.78 & 7.61 & 5.37 & 6.02 \\
\hline & $\mathrm{Ab}$ & 21.98 & 22.24 & 20.97 & 20.88 & 44.24 & 22.41 & 27.99 & 24.27 & 27.99 & 31.54 & 26.89 & 26.63 & 31.37 & 33.99 \\
\hline & An & 26.90 & 24.87 & 24.77 & 26.51 & 12.21 & 25.16 & 21.12 & 25.52 & 22.32 & 18.55 & 18.57 & 18.33 & 19.67 & 16.86 \\
\hline & $\mathrm{Ne}$ & 0.00 & 0.00 & 0.00 & 0.00 & 2.15 & 0.00 & 0.00 & 0.00 & 0.00 & 0.00 & 0.00 & 0.00 & 0.00 & 0.00 \\
\hline & (Wo & 8.54 & 7.59 & 9.81 & 5.42 & 7.02 & 6.65 & 4.49 & 11.54 & 7.96 & 4.63 & 7.03 & 7.92 & 8.59 & 7.95 \\
\hline \multirow[t]{2}{*}{$\mathrm{Di}$} & En & 4.83 & 4.65 & 5.21 & 3.24 & 3.19 & 3.49 & 2.22 & 6.09 & 4.89 & 2.22 & 3.29 & 3.96 & 4.26 & 3.77 \\
\hline & $F_{s}$ & 3.34 & 2.51 & 4.29 & 1.90 & 3.77 & 2.96 & 2.18 & 5.10 & 2.61 & 2.35 & 3.66 & 3.78 & 4.15 & 4.07 \\
\hline \multirow{2}{*}{$\mathrm{Hy}$} & En & 12.39 & 15.19 & 8.89 & 19.15 & 0.00 & 12.10 & 14.52 & 8.45 & 8.47 & 13.07 & 9.55 & 9.90 & 9.29 & 9.26 \\
\hline & $F_{s}$ & 8.58 & 8.19 & 7.32 & 11.22 & 0.00 & 10.26 & 14.22 & 7.07 & 4.52 & 13.86 & 10.62 & 9.45 & 9.06 & 9.99 \\
\hline \multirow{5}{*}{$\mathrm{Ol}$} & Fo & 0.00 & 3.10 & 0.00 & 0.00 & 4.30 & 0.00 & 0.00 & 0.00 & 7.53 & 0.00 & 0.00 & 0.00 & 0.00 & 0.00 \\
\hline & $\mathrm{Fa}$ & 0.00 & 1.84 & 0.00 & 0.00 & 5.61 & 0.00 & 0.00 & 0.00 & 4.44 & 0.00 & 0.00 & 0.00 & 0.00 & 0.00 \\
\hline & $\mathrm{Mt}$ & 1.72 & 1.90 & 1.69 & 1.90 & 1.79 & 1.95 & 2.53 & 1.84 & 1.98 & 2.53 & 2.20 & 2.01 & 2.04 & 2.20 \\
\hline & II & 0.61 & 0.69 & 0.59 & 0.67 & 2.15 & 0.99 & 2.10 & 1.31 & 1.58 & 2.30 & 1.85 & 1.41 & 1.73 & 2.15 \\
\hline & Ap & 0.07 & 0.02 & 0.09 & 0.02 & 0.46 & 0.07 & 0.21 & 0.16 & 0.21 & 0.14 & 0.19 & 0.19 & 0.23 & 0.28 \\
\hline
\end{tabular}

a Compiled from data of Wood et al. (this volume).

b Number, of analyses in parentheses if more than one.

c Calculated assuming $\mathrm{Fe}^{2}+/\left(\mathrm{Fe}^{2}++\mathrm{Fe}^{3+}\right)=0.86$.

western Pacific (Natland, crystal morphologies chapter, this volume). Olivine boninites contain, in addition to these minerals, phenocrysts of olivine and clinoenstatite, and fairly abundant magnesiochromite. The highly magnesian pyroxenes as well as the groundmass crystallization sequence allow these rocks to be clearly distinguished from both basalts and andesites (in which plagioclase crystallizes before augite) whether or not they are glassy (Natland, crystal morphologies chapter, this volume).

The two boninite sequences in Hole 458 are designated Types $A_{1}$ and $A_{2}$ in Figure $7 A$ and Table 2. Chemically, the rocks have the $\mathrm{SiO}_{2}$ range of typical mafic andesites $(52-59 \%)$ but high $\mathrm{MgO}(6-9 \%)$, $\mathrm{Ni}(100-200$ $\mathrm{ppm})$, and $\mathrm{Cr}(200-400 \mathrm{ppm})$. They have very low $\mathrm{TiO}_{2}$ (0.3-0.5\%), $\mathrm{Zr}(25-50 \mathrm{ppm})$, and Y (3-15 ppm). Some chemical variation within Chemical Type $\mathrm{A}_{1}$ (columns $2-4$, Table 2) suggests the presence of subunits, but their boundaries appear to have been obscured by alteration. Besides boninites, there are nine tholeiitic basalt types and subtypes in the two holes $\left(B_{1}\right.$ and $B_{2}$ in Hole 458; $\mathrm{B}_{1 \mathrm{~A}}, \mathrm{~B}_{1 \mathrm{~B}}$, and $\mathrm{B}_{2 \mathrm{~A}-\mathrm{E}}$ in Hole 459B). Apart from Type $B_{1 A}$, which has some chemical and mineralogical features suggesting that it is transitional to boninite compositions (cf. Natland, this volume, and discussion below), these various basalts have the geochemical features of island arc tholeiites (Wood et al., this volume; Meijer et al., this volume; Sharaskin, this volume), including $\mathrm{TiO}_{2}$ and $\mathrm{Zr}$ lower than in abyssal tholeiites (but higher than in boninites; Table 2), and low $\mathrm{Ni}$ and $\mathrm{Cr}$. Several of them are distinctly iron-enriched. They also have generally depleted rare earth element abundances, but moderate abundances of mobile elements such as $\mathrm{K}, \mathrm{Rb}, \mathrm{Ba}$, and Th (Wood et al., this volume; Hickey and Frey, this volume; Bougault et al., this volume). The two major chemical types, boninite and arc tholeiites, alternate in Hole 458 (Fig. 7A).

Magnetic units shown in Figure 7 are defined on the basis of one or more measurements of magnetic inclination which prove to be nearly identical in stratigraphic order, based on the data of Bleil (this volume). Sequential measurements no different from those that might be expected from the precision of the technique served to define magnetically coherent intervals in the core. These are designated by the average inclinations shown on Figure 7. In the case of both magnetic and chemical units, unit boundaries are assumed to be at the base or top of a core in which only one chemical and magnetic measurement apiece was made. This was the usual case for magnetic measurements, since recovery of oriented specimens was poor for most cores. In some cores, however, unit boundaries are within them. In these cases, the exact boundaries may have been impossible to determine, owing to the difficulty of determining chemistry on ad- 
jacent rock pieces (the sampling for shore-based X-ray fluorescence was done onboard ship) and the lack of oriented samples precisely across a magnetic transition. For these, unit boundaries are taken to be any obvious lithologic or petrographic transition in the core between the measured samples.

Chemical units are presumed to represent individual eruptive events. In a number of instances, chemical and magnetic boundaries coincide, implying that the lavas of those particular eruptive events "sampled" the earth's magnetic field at specific points in its history of secular variation and polarity reversals. Given the low latitude of the sites, and a latitude lower still during the Eocene (Bleil, this volume), secular variation totaling about $30^{\circ}$ could given rise to apparent reversals, although generally low inclinations would prevail. This could explain the numerous reversals in basalts of Hole 459B. The reversal in Hole 458 between Cores 40 and 41 , however, has an average difference in inclinations above and below (weighing each magnetic unit equally) of $37^{\circ}$, in excess of the secular variation. It also occurs across a transition between major chemical types $\left(A_{1}\right.$ and $B_{1}$ in Fig. 7). Therefore the eruptive pile could have built up across the period of a reversal in the Earth's magnetic field. Assuming that the reversal itself took about 2000 years to occur (Stacey, 1977), the total time over which the eruptions occurred might have been of the order of $0.5-1 \times 10^{4} \mathrm{y}$.

Changes in inclination and apparent reversals could also have been produced by faulting. In both holes, there are magnetic unit boundaries within clearly homogeneous chemical units. Some of these boundaries coincide with zones of intense fracturing in the rocks. Because these are almost certainly fault zones, the magnetic inclinations in part reflect rotation of fault blocks. However, the typical magnitude of such rotations is less than the average $37^{\circ}$ difference between the intervals of different polarity in Hole 458 basement. Since that major transition coincides with a chemical boundary as well, it seems likely that a reversal is indeed recorded in basement in Hole 458.

This has important consequences for the magmatic history of the fore-arc region. Both the major lava types that occur in Hole 458 (boninite and arc tholeiite) occur above and below the major magnetic reversal. None of the chemical types is identical to any other (Table 2); hence faulting has not repeated any chemical unit. Consequently, it appears that both magma types erupted alternately throughout a period sufficiently long for a reversal in the Earth's magnetic field to occur. The two chemical types do not belong to any sort of evolutionary sequence (as for example alkalic basalt cappings on tholeiitic oceanic volcanic edifices) but rather represent two distinct compositions supplied to the fore-arc region at much the same time.

This is not just a feature of Hole 458. Chemical data listed in Table 2 and pyroxene compositional data summarized in Natland (crystal morphologies chapter, this volume) show that Chemical Subtype $\mathrm{B}_{1 \mathrm{~A}}$ of Hole $459 \mathrm{~B}$, although petrographically a basalt, resembles boninite Type $A_{2}$ of Hole 458 . Both boninitic and basaltic lava fragments were obtained in talus deposits drilled beneath Eocene sediments (Ellis, this volume) deep in the Mariana Trench at Sites 460 and 461 (Sharaskin, this volume; Meijer et al., this volume). Lavas from these holes have arc tholeiite compositions (Wood et al., this volume). Boninites and "marianites" (which are boninites with abundant clinoenstatite) were also obtained in a dredge haul in the Mariana Trench near Guam (Dietrich et al., 1978; Sharaskin et al., 1980). These were associated with an "ophiolitic" assemblage of gabbros, norites, graywackes, and ultramafic rocks. A "low$\mathrm{TiO}_{2}$ basalt" from this dredge (compositionally a boninite) has a K/Ar age of 10.8 m.y. (Beccaluva et al., 1980). Another nearby dredge haul recovered island arc tholeiites (Sharaskin et al., 1980). Boninites and island arc tholeiites have been recovered in several other dredge hauls in the trench and form several fore-arc basement highs similar to that near Site 458 (S. Bloomer and J. W. Hawkins, personal communication). Meijer (1980) has pointed out that boninites series lavas occur in the Miocene Umatak Formation on the island of Guam. These overlie Eocene basalts and andesites and are associated with Miocene calc-alkalic lavas. Stark (1963) describes the boninitic lavas as basalts but notes that they are "hypersthene"-bearing, on the basis of parallel extinction, with hypersthene occurring in glomerophyric clots with augite. Plagioclase microlites are abundant in groundmass. These are the petrographic features of the more holocrystalline Hole 458 boninite pillows, although the latter contain bronzite phenocrysts (Natland, crystal morphologies chapter, this volume; Bougault et al., this volume; Meijer et al., this volume; Sharaskin, this volume). For comparison, chemical analyses of the Guam boninites are provided in Table 3.

In summary, we conclude that the boninite and arc tholeiite lava series were supplied to the Mariana arc and fore-arc region essentially simultaneously at most

Table 3. Compositions of boninites from Guam compared with a representative Hole 458 boninite.

\begin{tabular}{|c|c|c|c|c|c|c|}
\hline \multirow[b]{2}{*}{$\mathrm{SiO}_{2}$} & \multirow[b]{2}{*}{50.85} & \multicolumn{4}{|c|}{$\begin{array}{l}\text { Umatak Formation (Guam) } \\
\text { Boninite-type Lavas }\end{array}$} & \multirow{2}{*}{$\begin{array}{c}\begin{array}{c}\text { Sample } \\
458-39-2 \\
94-96 \mathrm{~cm} b\end{array} \\
52.5\end{array}$} \\
\hline & & & 51.63 & 54.2 & 55.0 & \\
\hline $\mathrm{Al}_{2} \mathrm{O}_{3}$ & 13.55 & & 14.10 & 14.6 & 13.8 & 15.7 \\
\hline $\begin{array}{l}\mathrm{Fe}_{2} \mathrm{O}_{3} \\
\mathrm{FeO}\end{array}$ & $\left.\begin{array}{l}2.24 \\
5.43\end{array}\right\}$ & $8.27^{c}$ & $\left.\begin{array}{l}2.27 \\
5.93\end{array}\right\} 8.86^{\mathrm{c}}$ & $\left.\begin{array}{l}5.1 \\
3.4\end{array}\right\} 8.9^{\mathrm{c}}$ & $\left.\begin{array}{l}3.8 \\
4.0\end{array}\right\} 8.2^{\mathrm{C}}$ & $9.43^{\mathrm{C}}$ \\
\hline $\mathrm{MgO}$ & 10.01 & & 9.93 & 8.0 & 9.4 & 9.16 \\
\hline $\mathrm{CaO}$ & 9.55 & & 9.47 & 7.9 & 7.9 & 8.39 \\
\hline $\mathrm{Na}_{2} \mathrm{O}$ & 1.58 & & 2.21 & 2.4 & 2.3 & 2.63 \\
\hline $\mathrm{K}_{2} \mathrm{O}$ & 0.16 & & 0.52 & 1.4 & 0.88 & 0.86 \\
\hline $\mathrm{TiO}_{2}$ & 0.34 & & 0.43 & 0.36 & 0.34 & 0.36 \\
\hline $\mathrm{P}_{2} \mathrm{O}_{5}$ & 0.03 & & 0.05 & 0.08 & 0.07 & 0.01 \\
\hline $\mathrm{MnO}$ & 0.14 & & 0.15 & 0.12 & 0.11 & - \\
\hline $\mathrm{H}_{2} \mathrm{O}^{+}$ & 1.91 & & 1.42 & 2.9 & 2.6 & - \\
\hline $\mathrm{H}_{2} \mathrm{O}^{-}$ & 4.13 & & 1.84 & 12.3 & 12.0 & - \\
\hline Total & 99.92 & & 99.95 & 100.46 & 100.20 & 99.20 \\
\hline $\mathrm{Ni}$ & 300 & & 200 & & & 99 \\
\hline $\mathrm{Cr}$ & 900 & & 700 & & & 217 \\
\hline $\mathrm{Zr}$ & 10 & & 10 & & & 35 \\
\hline Y & 30 & & 30 & & & $<1$ \\
\hline Sr & 200 & & 300 & & & 102 \\
\hline $\mathrm{Ba}$ & 20 & & 70 & & & 20 \\
\hline
\end{tabular}

a Data from Tracy and Stark (1963).

b Data from Wood et al. (this volume).

c Total iron as $\mathrm{Fe}_{2} \mathrm{O}_{3}$. 
locations in the Eocene, and again on the island of Guam during the Miocene. There is no indication in the drill sites or in any of the dredge hauls that genuine ocean crust exists either beneath the fore-arc sediments or at very great depths in the Mariana Trench. Such crust would have to be at least Early Cretaceous, and probably Jurassic, in age (Hussong and Fryer, this volume) and be overlain by some thickness of pelagic sediments. The fore-arc region is therefore not buttressed by major fault slices derived from the converging Pacific lithospheric plate.

\section{Alteration in Fore-arc Basement}

Many of the lavas in Holes 458 and 459B are extensively altered, especially along zones of intense fracturing of the rocks. A variety of clays and zeolites formed, and-mainly in Hole 459B - an unusual low-Al, high-Fe form of palygorskite (Natland and Mahoney, this volume) occurring exclusively in veins. The alteration was in two stages in both holes: (1) an early oxidative, possibly hydrothermal stage during which dioctahedral smectites, celadonite, palygorskite, calcite, and iron hydroxides formed and (2) a later, less oxidative stage in which di- and/or trioctahedral smectites and phillipsite formed. The latter occurred especially along zones of intense fracture in the lavas, which probably formed as a result of faulting of the fore-arc region. Profiler records indicate extensive normal faulting of the fore-arc, especially near Site 459 (Mrozowski and Hayes, 1980), where the sense of faulting is predominantly toward the trench. The idulting appears to be occurring even today, since Recent sediments have been affected by it (Hussong and Fryer, this volume). Takigami and Ozima (this volume) have obtained an apparently reliable age for the second-stage alteration in Hole 458 by ${ }^{40} \mathrm{Ar} /{ }^{39} \mathrm{Ar}$ incremental heating techniques. This age is about $10 \mathrm{~m} . \mathrm{y}$. younger than the age of the oldest (early Oligocene) sediments at the site.

The palygorskite in Hole 459B is its first reported occurrence in igneous basement. Elsewhere in the oceans, it has been reported only in pelagic or volcaniclastic sediments. Natland and Mahoney (this volume) speculate that it formed under oxidative hydrothermal conditions and that the second stage of alteration was caused by fluids circulating in the basement rocks whose compositions may have been different from those of fluids normally found in ocean crust. An important component of the fluids may have been derived from subducting ocean crust and sediments now only a few kilometers beneath the fore-arc region. The fluid compositions may have been additionally modified by having to travel along faults through a thick assemblage of mafic and ultramafic rocks similar to those drilled and dredged in the landward wall of the Mariana Trench.

\section{Geochemical Relationships among Lavas of Holes 458 and 459B}

Contributors to this volume generally agree that there is a spectrum of forearc parental types produced by the combined effects of different degrees (and possibly depths) of partial melting, and source heterogeneities.
There is also a general consensus that the sources differ from those of abyssal tholeiites, principally by addition of mobile constituents derived from the subducted ocean crust and sediments. Finally, it is apparent that the oxidation state of the magmas influenced fractionation, producing different degrees of iron, $\mathrm{TiO}_{2}$, and $\mathrm{SiO}_{2}$ enrichment.

These conclusions can be demonstrated using simple variation diagrams, such as those of Figures 8 and 9 on which the averaged data of Table 2 are plotted. Figure $8 \mathrm{~A}, \mathrm{TiO}_{2}$ versus total iron as $\mathrm{Fe}_{2} \mathrm{O}_{3}\left(\mathrm{Fe}_{2} \mathrm{O}_{3}^{\mathrm{T}}\right)$, shows that the boninites of Hole 458, as well as basalt Type $\mathrm{B}_{1 \mathrm{~A}}$ of Hole 459B, have systematically lower $\mathrm{TiO}_{2}$ and $\mathrm{Fe}_{2} \mathrm{O}_{3}^{\mathrm{T}}$ than the remaining basalts. Moreover, with only one exception, both boninites and basalts have systematically lower $\mathrm{TiO}_{2}$ at a given $\mathrm{Fe}_{2} \mathrm{O}_{3}^{\mathrm{T}}$ than abyssal tholeiites from the East Pacific Rise and Galapagos-Costa Rica Rifts showing comparable variation in $\mathrm{Fe}_{2} \mathrm{O}_{3}^{\mathrm{T}}$. This is one of the criteria by which Jakeŝ and Gill (1970) distinguished island arc tholeiites from mid-ocean-ridge basalts. The single exception on Figure $8 \mathrm{~A}$ is basalt Type $\mathrm{B}_{1}$ from Hole 458 (Table 3), which has unusually high $\mathrm{Na}_{2} \mathrm{O}$, low $\mathrm{MgO}$, and low $\mathrm{SiO}_{2}$. Its composition is based on a single analysis of rocks probably greatly modified by alteration. Even so, its $\mathrm{TiO}_{2}$ content compares only with the lowest $\mathrm{TiO}_{2}$ abundances found in abyssal tholeiites.

Three groups of rocks can be distinguished on a plot of $\mathrm{Fe}_{2} \mathrm{O}_{3}^{\mathrm{T}}$ versus $\mathrm{SiO}_{2}$ (Fig. 8B): a group of four boninites (here including Hole 459B Subtype $\mathrm{B}_{1 \mathrm{~A}}$ and the average bronzite andesite of Column 3, Table 3); a group of four low-SiO $\mathrm{S}_{2}$ tholeiites, two of which have marked iron enrichment (Type $\mathrm{B}_{2}$ of Hole 458 and Subtype $\mathrm{B}_{2 \mathrm{~A}}$ of Hole 459B); and a group of four high-SiO tholeiites (Subtypes $\mathrm{B}_{2 \mathrm{~B}-\mathrm{E}}$ of Hole $459 \mathrm{~B}$ ) which have less iron enrichment. They are also lower in $\mathrm{TiO}_{2}$ than the two most iron-enriched low- $\mathrm{SiO}_{2}$ tholeiites.

The variation diagrams of Figure 9 use $\mathrm{Zr}$ on the abscissa as an index of differentiation unaffected either by alteration or by oxidation state of the magmas. On several of these diagrams, the three major groups fall into different fields, and on some they overlap. For reference, the least fractionated arc tholeiite (Subtype $\mathrm{B}_{1 \mathrm{~B}}$ of Hole 459) and the most iron-enriched from the same hole (Subtype $\mathrm{B}_{2 \mathrm{~A}}$ ) are connected by a solid line. The most fractionated basalt type, with the highest $\mathrm{Zr}$ and $\mathrm{Y}$, and the lowest normative $\mathrm{An} / \mathrm{An}+\mathrm{Ab}$, is Type $\mathrm{B}_{1}$ of Hole 458, the altered sample mentioned earlier. $\mathrm{Zr}$, Y, and $\mathrm{TiO}_{2}$ should not have been much affected by the alteration. Consequently, this basalt has surprisingly lower $\mathrm{TiO}_{2}$ and $\mathrm{Fe}_{2} \mathrm{O}_{3}^{\mathrm{T}}$ than the two iron-enriched basalts, even though it appears to be more fractionated on the basis of trace elements. Either iron enrichment among its precursors was not as extreme, there was a marked late-stage fractionation of titanomagnetite (contrasting dashed arrows on Figs. 8 and 9), the source of its parent in the mantle was less depleted than the source of the other basalts, or its parent was a smaller partial melt.

The high-SiO $\mathrm{O}_{2}$ basalts overlap the iron-rich tholeiites in $\mathrm{Y}, \mathrm{Zr}$, and $\mathrm{TiO}_{2}$ on Figure 9 variation diagrams but have lower $\mathrm{Mg} / \mathrm{Mg}+\mathrm{Fe}$ and normative $\mathrm{An} / \mathrm{An}+\mathrm{Ab}$. 


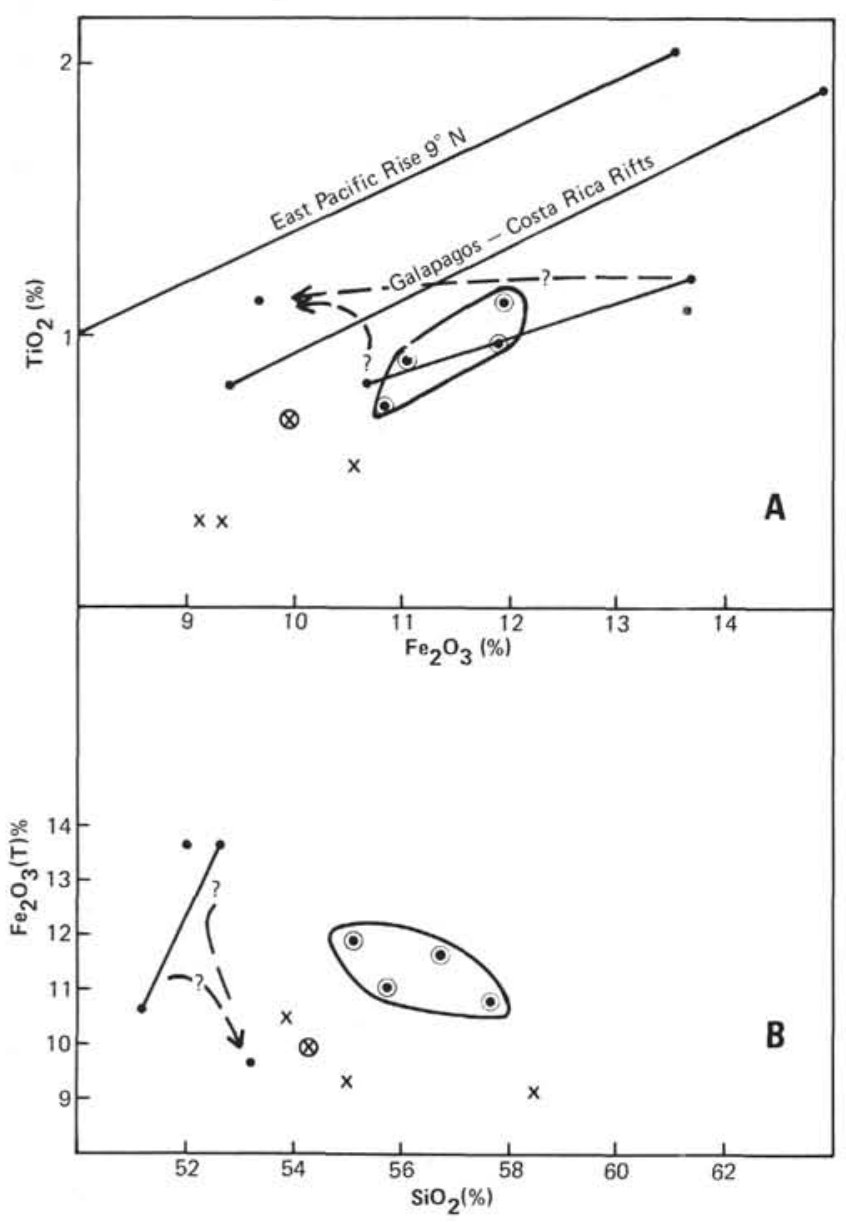

Figure 8. A. $\mathrm{Fe}_{2} \mathrm{O}_{3}(\mathrm{~T})$ versus $\mathrm{TiO}_{2}$ for basalts and boninites of Holes 458 and $459 \mathrm{~B}$, using average data of Table 2. Trend lines for East Pacific Rise and Galapagos-Costa Rica rifts fractionation trends are based on glass compositions in Natland and Melson (1980) and unpublished data. ( $\mathrm{X}=$ boninites, $\otimes=$ Subtype $\mathrm{B}_{1 \mathrm{~A}}$ of Hole 459B, $\bullet=$ low $\mathrm{SiO}_{2}$ tholeiites, and $\odot=$ high $\mathrm{SiO}_{2}$ tholeiites.) $\mathrm{B}$. $\mathrm{SiO}_{2}$ versus $\mathrm{Fe}_{2} \mathrm{O}_{3}(\mathrm{~T})$ for average data of Table 2. (Same symbols as A. Solid lines on A and B connect least and most fractionated Hole 459B low $\mathrm{SiO}_{2}$ tholeiites. Dashed arrows are possible alternative paths of fractionation to Hole 458 Type $B_{1}$ basalt.)

They have $2.5 \%-6.5 \%$ higher $\mathrm{SiO}_{2}$. Within the four high- $\mathrm{SiO}_{2}$ basalts, however, $\mathrm{SiO}_{2}$ decreases with increasing $\mathrm{Zr}, \mathrm{Y}, \mathrm{TiO}_{2}$, and $\mathrm{Fe}_{2} \mathrm{O}_{3}^{\mathrm{T}}$, contrary to what might be expected from a normal fractionation sequence. The normative ratio $\mathrm{An} / \mathrm{An}+\mathrm{Ab}$, however, decreases in a way consistent with fractionation.

These are complex variations, unlike the simple trend toward iron enrichment shown by eastern Pacific ferrobasalt suites (cf. Clague and Bunch, 1976; Natland and Melson, 1980). If all the tholeiitic basalts are related to a single parent, then some of the variation in $\mathrm{TiO}_{2}$, $\mathrm{Fe}_{2} \mathrm{O}_{3}^{\mathrm{T}}$, and $\mathrm{SiO}_{2}$ might be related to variable fractionation of titanomagnetite, together with plagioclase and clinopyroxene. This would simultaneously suppress enrichment in $\mathrm{Fe}_{2} \mathrm{O}_{3}^{\mathrm{T}}$ and $\mathrm{TiO}_{2}$ and promote $\mathrm{SiO}_{2}$ enrichment (Osborne, 1959, 1962, 1979). The parent, however, would have to be far more magnesian and less siliceous than the least-fractionated basalt, Subtype $B_{1 B}$ of Table 2. Moreover, the extent of titanomagnetite frac- tionation would not be the same for any of the high$\mathrm{SiO}_{2}$ tholeiites, since the least evolved of those in terms of $\mathrm{Y}$ and $\mathrm{Zr}$ (Subtype $\mathrm{B}_{2 \mathrm{C}}$ ) has the highest $\mathrm{SiO}_{2}$.

There is little reason, however, to suppose that a common parent was involved. Instead, the low- $\mathrm{SiO}_{2}$ tholeiites have systematically higher $\mathrm{Zr}$ at a given $\mathrm{Ni}$ contents (Fig. 9H) than the high-SiO ${ }_{2}$ tholeiites; hence one might suppose that the parent to the latter represents a greater degree of melting of a homogeneous source than the parent of the low- $\mathrm{SiO}_{2}$ tholeiites. This is based on an argument by Bougault et al., (1978) that $\mathrm{Ni}$ is insensitive, whereas elements such as $\mathrm{Zr}$ are quite sensitive, to variations in the degree of melting in an olivine-rich peridotitic source. In terms of most of the oxides and trace elements considered in Figures 8 and 9, we can even say that such a parent would have approached boninite compositions and that the high- $\mathrm{SiO}_{2}$ tholeiites would be iron-enriched with respect to such a parent.

We therefore propose that the mantle source of the Mariana fore-arc region produced a spectrum of parental compositions ranging from olivine boninite to olivine tholeiite and that different oxidation states in the tholeiite magmas produced variable $\mathrm{SiO}_{2}$ enrichment and $\mathrm{TiO}_{2}$ and iron depletions. There is some petrographic evidence for this. Titanomagnetite is particularly abundant in Hole 459 tholeiites (indeed, it is so abundant that it produces intensities of magnetization 3-5 times higher than in even more iron-enriched abyssal tholeiites; Bleil, this volume). Some of the basalts contain segregation vesicles in which titanomagnetite is the only well-crystallized phase, indicating high oxygen fugacities in the vesicles (Natland, crystal morphologies chapter, this volume). Exactly at what stages titanomagnetite entered fractionation sequences is not clear. This may have depended on concentrations of volatiles in the mantle sources. What is clear is that its impact was quite variable, possibly reflecting conditions in magma chambers and conduits that held these magmas. Some of the chemical contrasts among the basalt types could also have been caused by mixing variably fractionated and oxidized magma batches. Whatever the case, it now seems that in consideration of a suite of rocks, variable iron, $\mathrm{TiO}_{2}$, and $\mathrm{SiO}_{2}$ enrichments may characterize many island arc tholeiites and be useful as discriminants between these and ocean floor basalts. A given arc tholeiite may not be particularly iron-enriched, or indeed much fractionated, but it still can be distinguished from abyssal tholeiites by having lower $\mathrm{TiO}_{2}$ at a given total iron abundance (Fig. 8A).

Both the basalts and the boninites of Holes 458 and 459B have fractionated compositions. No compositions potentially representative of parental compositions were recovered. This has been explicitly determined experimentally for the Hole 458 boninites by Kushiro (this volume), who inferred that they did not melt in equilibrium with a hydrous plagioclase lherzolite mantle but instead seem to be derived from an olivine boninite parent which did. This is also indicated by the absence of both clinoenstatite and olivine in Hole 458 boninites and their somewhat low $\mathrm{MgO}$ contents. 


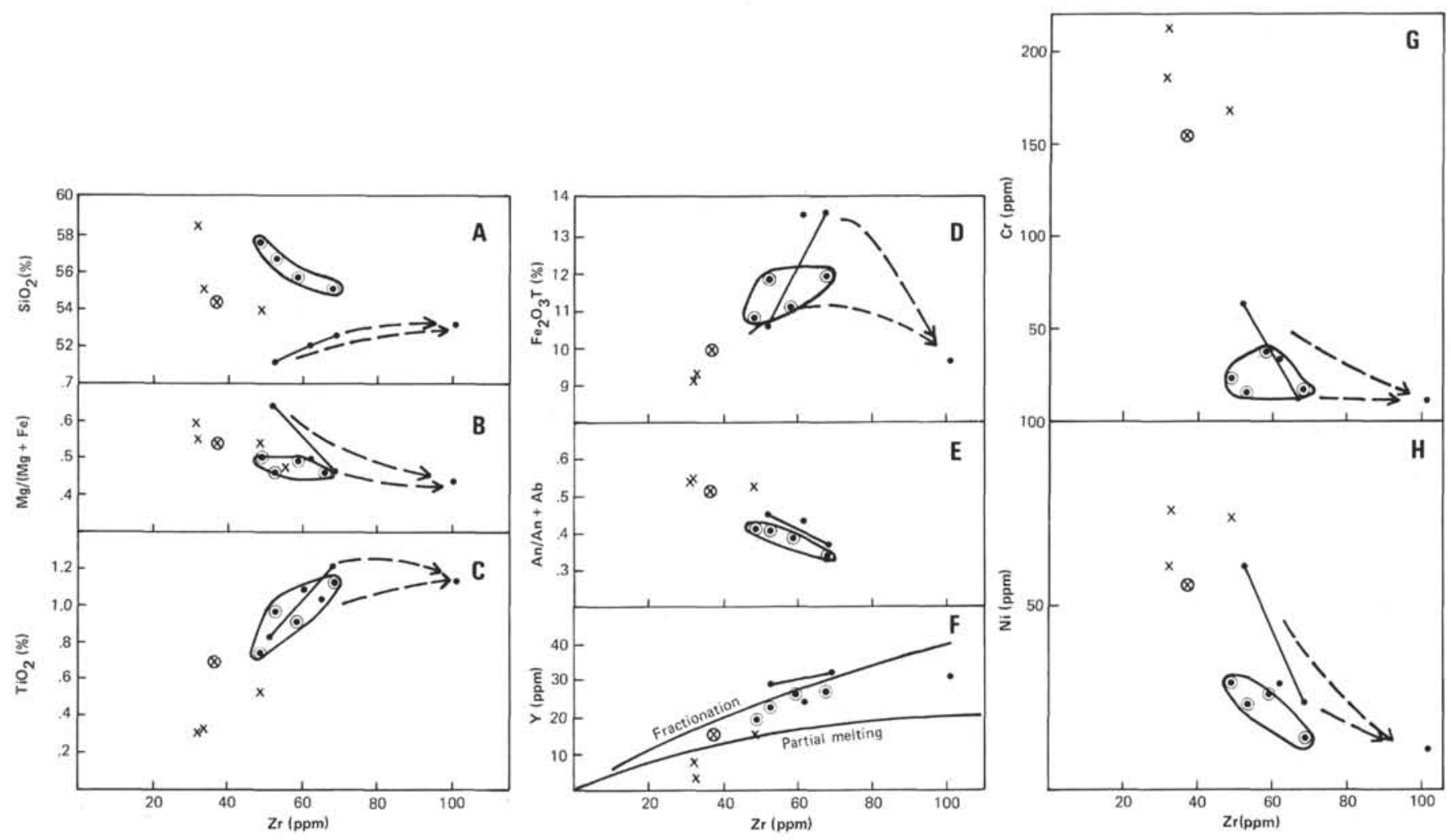

Figure 9. $\mathrm{Zr}$ variation diagrams for average chemical types and subtypes and subtypes of Holes 458 and 459B, from Table 2. (Symbols as in Figure 8A). A. $\mathrm{SiO}_{2}-\mathrm{Zr}$; B. $\mathrm{Mg} /(\mathrm{Mg}+\mathrm{Fe})-\mathrm{Zr}$; C. TiO $\mathrm{O}_{2}-\mathrm{Zr} ; \mathrm{D} . \mathrm{Fe}_{2} \mathrm{O}_{3}(\mathrm{~T})-\mathrm{Zr} ;$ E. Normative $\mathrm{An} /(\mathrm{An}+\mathrm{Ab})-\mathrm{Zr}$; F. Y $-\mathrm{Zr}$ with fractionation and partial melting trends of MORB suites from Tarney et al. (1979); G. Cr-Zr; H. Ni-Zr.

\section{Contrasts to MORB and the Compositions of Fore-arc Mantle Sources}

Data contributed to this volume and to DSDP Volume 59 (Kroenke, Scott, et al., 1980) add to the growing body of information on the distinctive geochemistry of island arc lavas. As summarized from Wood et al. (this volume), Bougault et al. (this volume), and Hickey and Frey (this volume), the island arc tholeiites of Holes 458 and $459 \mathrm{~B}$ differ from MORB in the following ways: (1) They have lower $\mathrm{Ti}$ and $\mathrm{Zr}$ and higher $\mathrm{Ti} / \mathrm{Zr}$ at a given $\mathrm{MgO}$ content despite equivalent or greater iron enrichment; (2) Overall, they have lower rare-earth element abundances despite being generally more fractionated. However, they have similar or even somewhat greater light rare-earth element depletion; (3) Although they have lower $\mathrm{Zr}, \mathrm{Ti}$, and $\mathrm{Hf}$ than MORB, the abundances of these elements are not as low relative to the depleted rare-earth element abundances as in MORB; (4) Ta and $\mathrm{Nb}$ are even more depleted than rare-earth elements when compared with MORB; (5) Highly incompatible elements such as $\mathrm{Cs}, \mathrm{K}, \mathrm{Rb}, \mathrm{Ba}, \mathrm{Pb}, \mathrm{U}$, and Th are enriched in the arc tholeiites compared with MORB and their own depleted rare-earth element abundances; (6) The arc tholeiites have higher ${ }^{87} \mathrm{Sr} /{ }^{86} \mathrm{Sr}(0.7036-0.7038)$ than MORB (Armstrong and Nixon, 1980), although some of this may have resulted from alteration.

Despite having erupted apparently contemporaneously with the arc tholeiites, the Hole 458 boninites cannot have been derived from a similar mantle source, although they, too, differ significantly from MORB. Their very low abundances of $\mathrm{Ti}, \mathrm{Zr}$, rare-earth elements, and other highly incompatible elements and their high $\mathrm{MgO}, \mathrm{Ni}$, and $\mathrm{Cr}$ indicate that their presumed olivine boninite parent was a high partial melt of the mantle. Wood et al. (this volume), Meijer et al. (this volume), and Kushiro (this volume) argue from various standpoints that melting occurred under hydrous conditions and that the source was refractory (had experienced a previous melting episode of basalt extraction).

Normally, one would expect that combining high partial melting and a refractory source, would result in considerable depletions in highly incompatible elements; not so with these lavas. They are even more enriched, relative to their rare-earth element abundances, in large ion lithophile elements such as $\mathrm{K}, \mathrm{Rb}, \mathrm{U}$, and Th than the associated arc tholeiites, or than MORB. In this respect, they display the characteristics of calcalkalic suites. They show an even more marked enrichment of $\mathrm{Zr}$ relative to $\mathrm{Ti}$ than the arc tholeiites (although overall abundances of both are quite low). However, they do not show the depletion in $\mathrm{Ta}$ and $\mathrm{Nb}$ relative to rare-earth elements of the arc tholeiites.

When the spectrum of magmatic processes that have acted on these volcanic rocks is put in perspective, it is evident that although fractionation and even melting processes have been important, the distinctive features of these rocks relate to their source compositions. $\mathrm{Pe}$ trogenetic models proposed by contributors to this volume quite naturally have this as their major concern. 
There is, for example, agreement among Wood et al. (this volume), Hickey and Frey (this volume), and Bougault et al. (this volume) that the mantle sources have been enriched in large ion lithophile elements, probably by fluids derived from the subducting ocean crust and its sediments (e.g., Hawkesworth et al., 1979; Saunders et al., 1980, Kay, 1980). Wood et al. (this volume) explain the refractory behavior of $\mathrm{Ti}, \mathrm{Ta}$, and $\mathrm{Nb}$ by arguing that a Ti-rich phase such as rutile or sphene is stable under hydrous conditions and retains these elements during the partial melting of a hydrous mantle source (Hellman and Green, 1979). The lack of Ta and Nb depletions in the high-MgO bronzite andesites, they suggest, reflects the exhaustion of such a phase or phases during extreme partial melting. The unusual enrichment in $\mathrm{Zr}$ and $\mathrm{Hf}$ relative to $\mathrm{Ti}, \mathrm{Y}$, and the heavy rare-earth elements is more difficult to explain by crystal-melt relationships and would require retention of $\mathrm{Ti}$ and the heavy rare earths in garnet during melting (Wood et al., this volume) or replenishment of the mantle source with incompatible elements such as $\mathrm{Zr}$ and $\mathrm{Hf}$ in addition to $\mathrm{K}, \mathrm{Rb}, \mathrm{U}$, Th, etc.

\section{Models for Fore-arc Magmatism}

Reconciling these geochemical features with plausible tectonic-magmatic sequences in the Mariana arc system has not produced unanimity of opinion. Most petrologic contributors to this volume have seized on the Eocene-Oligocene age of the boninite series lavas in the Bonin Islands and at Site 458 as an indication that these unusual lavas are somehow restricted to eruption during the earliest stages of arc volcanism only. Meijer et al. (this volume) and Meijer (1980), for example, suggest that at the onset of subduction, cold hydrous ocean crust is suddenly plunged into hot mantle. The consequent release of water from the subducted crust into the hot mantle suppresses the liquidus sufficiently to initiate melting, and a spectrum of magma types is produced as the zone of melting rises from the vicinity of the subduction zone to shallower levels in the mantle wedge above it. Boninites are produced when melting reaches as shallow as 40 to $60 \mathrm{~km}$ below the seafloor. As subduction continues, the temperature of the mantle around the subducted lithosphere is lowered, and because the zone of melting cannot rise to such shallow depths, boninites cease to erupt. This hypothesis, however, does not take into account either the early Miocene boninites on Guam or late Miocene (10.8 Ma) boninite lavas dredged near Guam. For the latter, Beccaluva et al. (1980) propose that the thermal conditions necessary to produce boninites were reestablished by a rise in isotherms at the initiation of Mariana Trough back-arc basin spreading. This could have caused additional melting of shallow, but nevertheless refractory, subarc mantle. Hickey and Frey (this volume) and Wood et al. (this volume) have discussed models in which the mantle above the ocean crust becomes progressively enriched in the highly incompatible elements as subduction proceeds. Hickey and Frey relate this specifically to the sequence of volcanism recorded in Hole 458, in which the relatively more enriched boninites rest stratigraphically above the arc tholeiites. Meijer (1980) made the similar point that boninite series lavas seem to occur later in volcanic successions on Guam and the Bonin Islands as well as in Hole 458. In our view, the evidence for later eruption of boninites is circumstantial and based on extremely restricted outcroppings or drill holes. In Hole 458, the two magma series clearly alternate. Mattey et al. (1980) and Wood et al. (this volume) make the more general point that the Mariana arc as a whole has evolved to more calc-alkalic compositions, especially on the West Mariana Ridge and the currently active arc, and that this entails steady enrichment in the mantle of the mobile incompatible elements. They mention the similarities between boninite series and calc-alkalic series lavas in these elements. Hickey and Frey (this volume) demonstrate that boninites show quite variable enrichments in light rare-earth element abundances. This suggests to them that reenrichment of depleted mantle sources by the highly mobile incompatible elements can result in a continuum of depleted to enriched boninite series lavas.

Meijer et al. (this volume), Wood et al. (this volume), and Hickey and Frey (this volume) all favor an origin for arc tholeiites in the mantle above the subducting oceanic lithosphere. Of these authors, only Wood et al. (this volume) propose that the depleted source of the boninites was originally the uppermost mantle of the subducting lithosphere from which abyssal tholeiites had been extracted. Upon deep descent into the mantle during subduction, this refractory peridotite would become lighter than surrounding mantle from which basaltic melts had not been extracted, probably because it would contain comparatively less of the dense iron-rich phase, garnet. It would then ascend diapirically into the mantle above the subducting lithosphere, there to become variably reenriched in mobile elements also derived from the subducting crust.

This proposal is similar to that of Kay (1980), who favored derivation of the entire suite of island arc magmas from rising depleted peridotite diapirs originating from within the subducting lithosphere, based on the low abundances of $\mathrm{Ti}, \mathrm{Nb}, \mathrm{Zr}$, and heavy rare-earth elements in all of them (Green, 1976; Sun and Nesbitt, 1978). Variable contamination with subducted sediments and seawater again would cause the enrichments in highly mobile incompatible elements. The magmas could also be modified to a greater or lesser extent by crystal fractionation prior to eruption.

On geochemical grounds, however, it is still impossible to distinguish between models favoring subduction zone melting (e.g., Ewart et al., 1977), shallower melting of depleted diapirs rising from the subducting lithosphere (Kay, 1980), or melting of the mantle above the subduction zone after it has been hydrated and variably enriched in highly mobile incompatible elements (Ringwood, 1974; Thorpe et al., 1976; Hawkesworth et al., 1979; Saunders et al., 1980). All of these models require ways of simultaneously depleting melts in $\mathrm{Ti}, \mathrm{Zr}, \mathrm{Hf}$, $\mathrm{Ta}, \mathrm{Nb}$, and, sometimes, $\mathrm{P}$, and enriching in $\mathrm{K}, \mathrm{Rb}, \mathrm{Ba}$, $\mathrm{Th}, \mathrm{U}, \mathrm{Cs}$, and radiogenic strontium. The depletions are accomplished either by a two-stage melting process, in which a previous extraction of basalt has occurred, or 
by stabilization under hydrous conditions of minor phases such as rutile, sphene, and apatite, which retain the relatively depleted elements during melting. Saunders et al. (1980) argue that the latter could occur anywhere near the hydrous part of the subducting crust, leaving only the mobile incompatible elements to escape during dehydration. Once this has occurred, however, it would seem that melting could occur either in the subduction zone or in rising diapirs and produce the same geochemical anomalies, provided adequate enrichment or reenrichment in the mobile elements also occurs.

Experimental evidence for the actual depth of segregation of island arc parental materials from the mantle favors shallow depths rather than the great depths of typical subduction zones. Experimental data indicate that boninites could have melted in equilibrium with hydrous peridotite at depths corresponding to about 10-20 kbar (e.g., Kushiro, 1972, 1974, and this volume; Green, 1973, 1976; Nicholls and Ringwood, 1973; Nicholls, 1974; Mysen et al., 1974; Mysen and Boettcher, 1975a, $1975 \mathrm{~b})$. In their review of the chemical characteristics of island arc basalts, Perfit et al. (1980) conclude that the major oxide differences between arc basalts and MORB are not a consequence of differences at the source but appear to reflect different crystallization histories: Notably, arc basalts have less initial plagioclase fractionation and more clinopyroxene fractionation. This, these authors argue, is a consequence either of higher $p\left(\mathrm{H}_{2} \mathrm{O}\right)$ or greater depths of crystallization. We have argued that variable oxidation states of arc basaltic magmas cause different enrichments in total iron, $\mathrm{TiO}_{2}$ and $\mathrm{SiO}_{2}$. This might be related to a more hydrous mantle source than that of MORB, but this does not imply a greater depth of melting. There is no important compositional feature of these basalts to indicate depths of melting significantly greater than those of ocean floor basalts. The latter have been interpreted to originate at depths of about 30 km (9-10 kbar; e.g., Kushiro, 1973; Fujii et al., 1978; Bender et al., 1978; Presnall et al., 1979) or perhaps twice that much (e.g., Duncan and Green, 1980; Stolper, 1980; Jaques and Green, 1980). Similar depths of origin seem preferred for boninites, as already discussed. These conclusions are consistent either with melting of peridotite diapirs rising from the subducting lithosphere or with the direct melting of mantle above the subduction complex itself, following its hydration and enrichment in mobile incompatible elements.

The two magma types, arc tholeiites and boninites, can be viewed as complements in a direct melting model, with boninites derived from the refractory mantle produced by extraction of the former. The situation would be analogous to that of the FAMOUS area on the MidAtlantic Ridge, where continued melting of a mantle from which basalts have been extracted has been invoked to explain the interbedding or close spatial proximity of sparsely plagioclase phyric and strongly olivine phyric basalts (Langmuir et al., 1977; Natland, 1978; Duncan and Green, 1980). The differences would be (1) that the mantle beneath the Mariana fore-arc was more hydrous and (2) that variable external enrichment in mobile elements was occurring. Based on Holes 458 and $459 \mathrm{~B}$, it is our belief that olivine boninites and olivinebearing parents to arc tholeiites are end components of a continuum of parental compositions supplied to the Mariana fore-arc region during late Eocene-early Oligocene times. Whether intermediate magma types may have been produced by hybridization between these end components is uncertain. But there is no reason why many of them could not have been derived directly from variably refractory and hydrated sources in the mantle. The existence of such a continuum implies that the end component magma types were simultaneously available, as argued earlier on stratigraphic grounds, and probably means that their sources were not too greatly separated spatially in the mantle. In other words, a deep source for arc tholeiites, and a shallow source for boninites (e.g., Meijer, 1980), seems unlikely.

\section{Boninite Constraints on Arc-Trench Geometry}

The eruptive sources of lavas to Sites 458 and 459 were probably not far away, certainly not as far away as the present Mariana arc or even the ancestral Mariana arc which may have been on the northern extension of the ancestral Guam-Saipan arc (Fig. 1). This would have been over $100 \mathrm{~km}$ to the west. If we assume that melting occurred more or less directly beneath the two sites, then great changes in the geometry of subduction must have occurred since the Eocene. The present depth to the top of the subducted oceanic lithosphere beneath Site 459 is no more than $\mathbf{2 0 - 3 0 ~ k m ~ ( H u s s o n g ~ a n d ~ F r y e r , ~}$ this volume), shallower than the experimentally estimated depth of segregation of boninites. If, as argued by Wood et al. (this volume), boninites and possibly island arc tholeiites arose from diapirs of hydrous peridotite emanating from the subducted lithosphere that ascended through a denser garnet-bearing mantle, then the subduction zone was originally $100 \mathrm{~km}$ or more beneath Site 458 and 459 . Even if melting was confined to shallower mantle never invaded by such diapirs, the depth to the subduction zone would still have had to be considerably more than it is now. We believe that this is consistent with tectonic removal, since the Eocene, of portions of the eastern edge of the fore-arc region by processes related to subduction. There is evidence from seismic profiler records for present-day downfaulting of the edge of the fore-arc into the Mariana Trench (Mrozowski and Hays, 1980; Hussong and Fryer, this volume), and it is evident that arc-related igneous and metamorphic rocks crop out in the trench wall (e.g., Dietrich et al., 1978; Beccaluva et al., 1980; Sharaskin et al., 1980; Meijer et al., this volume; Sharaskin, this volume; Wood et al., this volume; Sites 460 and 461 chapters, this volume; S. Bloomer, personal communication). The result of this tectonic process has been to shift the zone of subduction westward relative to Sites 458 and 459 , and probably even farther to the west at the northern and southern ends of the Mariana arc, where the fore-arc region is narrower than near $18^{\circ} \mathrm{N}$. 


\section{Mariana Fore-arc Ophiolite}

The Mariana fore-arc is a plateau-like region between the high subaerial volcanoes of the Mariana arc and the abrupt chasm of the Mariana Trench. Beneath the sediment drape which thickens toward the arc, fore-arc basement averages between $4 \mathrm{~km}$ and $5 \mathrm{~km}$ below sea level, with local elevations as shallow as $1.5 \mathrm{~km}$. On the basis of Leg 60 drilling, the top of this basement appears everywhere to have been produced by Eocene-late Oligocene arc volcanism. The drilling also demonstrated that this region has always been in fairly deep water and, except possibly locally, has never been uplifted. Within and near the Trench, in fact, subsidence has clearly occurred, as evidenced by the Trench Sites 460 and 461 , which have subsided below the carbonate compensation depth since the late Oligocene (see Sites 460 and 461 chapters, this volume). Normal faults are abundant near the Trench (Mrozowski and Hayes, 1980; Mrozowski et al., this volume); some even affect Recent sediments (Hussong and Fryer, this volume).

Seismic refraction studies show that the crust of the fore-arc is somewhat thicker and has lower velocities than either normal ocean crust or back-arc basin crust. However, it is not grossly different from either. Velocities approach $5.6-6.1 \mathrm{~km} / \mathrm{s}$ uniformly at depths of $4.5 \mathrm{~km}$ below the seafloor throughout the fore-arc region (Hussong and Fryer, this volume). But "on the basis of seismic velocities only, it is impossible to determine whether the uppermost layer 3 material beneath the fore-arc is composed of arc volcanics or is old backarc basin or oceanic crust that has been buried by, and now serves as the foundation for, more recent arc volcanics" (LaTraille and Hussong, 1980, p. 215).

The total thickness of the crust increases to the west beneath the Mariana arc (Hussong, this volume, Plate 2 , back pocket). The crust of the Palau-Kyushu Ridge is of comparable thickness (Murauchi et al., 1968). There is now, and there was in the Eocene, a thicker crustal root beneath shallow portions of the arc system, where there are, or were, lines of active shallow or subaerial volcanoes.

The structural relationship between the fore-arc lavas and those of the higher Eocene volcanoes of Guam, Saipan, and the Palau-Kyushu Ridge is not clear. But the recovery of gabbros and ultramafic rocks in the wall of the Trench (Dietrich et al., 1978; Beccaluva et al., 1980; Sites 460 and 461 chapters, this volume; S. Bloomer and J. Hawkins, personal communication), in many cases associated with or close to evident outcrops of arc tholeiites and boninites, is strong evidence that fore-arc crust is quite thin and lacks any component of faulted-in ocean crust. The arc volcanics appear directly to overlie gabbros and ultramafic rocks, and it is logical to presume that the gabbros and cumulus ultramafic rocks consolidated in fore-arc rather than in ocean crust magma chambers. Put another way, for the gabbros and ultramafic rocks to have originated in the ocean crust, one would have to suppose the existence of a fault or faults which removed all vestige of several hundred meters of Jurassic and younger marine sediments and of several kilometers of Layer 2 pillow basalts from the top of the ocean crust section and subducted these without subducting the deeper and denser gabbros and ultramafic rocks. This would probably also have caused uplift of the outer part of the fore-arc region, whereas subsidence has occurred. The arc lavas would now be in fault or depositional contact with the plutonic rocks.

We have summarized evidence that the arc tholeiites in particular, but also the boninites, of Holes 458 and 459B are quite fractionated lavas. A complementary suite of cumulus gabbros must exist somewhere in the fore-arc crust. Earlier we noted that calc-alkalic gabbros were dredged from the Mariana Trench near Guam (Dietrich et al., 1978). It is possible that Seismic Layer 3 of the fore-arc is made up almost entirely of cumulus gabbros involved in the fractionation of arc tholeiites, boninites, and even calc-alkalic lavas.

In short, we propose that the Mariana fore-arc region is an in situ ophiolite succession with appropriately thin crust, a reasonably typical velocity structure (probably modified by serpentinization and the extensive faulting that has occurred), and the necessary upper pillowed extrusive sequence overlying appropriate plutonic rocks. It was produced during the early stages of arc volcanism and is not a fragment of ocean crust.

Exactly how this crust was produced must remain a matter for speculation. Cameron et al. $(1979,1980)$ have pointed to the occurrence of boninites in some ophiolites including Troodos and, because of the boninites dredged and drilled from the Mariana Trench and forearc, proposed that they formed in fore-arc settings. Troodos is one ophiolite that has a particularly welldeveloped sheeted dike complex (Gass, 1963; Moores and Vine, 1971; Kidd, 1977; Coleman, 1977), which is normally taken to indicate an origin by seafloor spreading. Miyashiro (1973) argued for an island arc rather than ocean crust origin for Troodos on the basis of geochemistry, a suggestion that was not well received primarily because Troodos simply does not look structurally like an island arc but instead resembles ocean crust, or at least some type of back-arc basin. The discovery of boninites in the Troodos complex pillow lavas implies that Miyashiro (1973) was right, as Cameron et al. (1980) have argued, but what now should be made of Troodos's ocean crust type of structure?

We suggest that an appropriate equivalent of Troodos in an island arc setting is the Mariana fore-arc region and that at the earliest stages of arc volcanism, a type of seafloor spreading may have occurred before volcanism focused along the line of the arc. Such an early spreading episode is not unreasonable in a tectonic setting that has twice subsequently experienced arc rifting and formation of back-arc spreading basins. Whether or not true sea-floor spreading produced the Mariana fore-arc region remains to be seen in the light of more detailed geophysical experiments, careful dredging in the Trench, and perhaps drilling. Regardless, the occurrence of bo- 
ninites in certain ophiolites is good evidence that spreading has occurred in several ancient arc systems, probably early in their history.

\section{PART II. STRUCTURAL AND MAGMATIC EVOLUTION OF THE MARIANA ARC SYSTEM}

\section{Trapped Ocean Crust, Inactive Arcs, and Back-arc Basins in the Philippine Sea}

Here we review some of the more important results of Legs 58 and 59 and integrate them with the Leg 60 data summarized in Part I to provide an overall view of the evolution of the Mariana arc system. The two earlier legs provided valuable information on the West Philippine Sea, the Palau-Kyushu Ridge, and the Parece Vela Basin, information which is important in understanding the early stages of arc development. The location of sites drilled during Legs 58 and 59 are shown on Figure 1. Details of the petrology of igneous rocks recovered during these legs are in numerous chapters in Klein, Kobayashi, et al. (1980) and in Kroenke, Scott, et al. (1980).

\section{West Philippine Basin}

Hilde et al. (1977) have proposed that the West Philippine Basin (Fig. 1), lying between the Ryukyu Arc at the Asian plate boundary to the west and the PalauKyushu Ridge to the east, is "trapped" in origin, being part of normal Pacific ocean floor which became separated from the main ocean as a result of initiation of subduction along the line of the present Palau-Kyushu Ridge. They suggested that the eastern boundary of the West Philippine Sea may initially have been an old N-S transform fault which changed to a convergent plate boundary consequent upon a change in direction of $\mathrm{Pa}$ cific plate motion from northerly to westerly some 45 Ma (cf. Jurdy, 1979). Scott et al. (1980), although recognizing this possibility, have constructed arguments which consider the West Philippine Sea as having formed by back-arc spreading but related to the Oki-Daito Ridge as a potential early Tertiary island arc (Karig, 1975) rather than to the Palau-Kyushu Ridge.

Magnetic lineation patterns in the West Philippine Basin have been studied by Louden (1976), Watts et al. (1977), and Shih (1980) and, together with earlier evidence from deep sea drilling (Sites 290-295; Karig, Ingle, et al., 1975), suggest that active spreading occurred in the early Tertiary $(\sim 62-39 \mathrm{Ma})$, with the NW-SWtrending Central Basin "Fault" representing the extinct spreading center (Ben-Avraham et al., 1972). The younger magnetic anomalies (18-20) are particularly well defined (Watts et al., 1977) and suggest a (half-)spreading rate of $4.4 \mathrm{~cm} / \mathrm{y}$.; the older anomalies, though less well defined, indicate a much faster spreading rate. Andrews (1980) has suggested that the spreading direction may have changed $54 \mathrm{Ma}$ from northeasterly to northerly.

Andesite, basalt, and granodiorite have been recovered from the Oki-Daito Ridge, and andesite, diorite, hornblende schists, and serpentine have been dredged from the Daito Ridge; justifiably it has been suggested that these two ridges represent old island arcs (Murauchi et al., 1978; Karig, 1975; Mizuno et al., 1975, 1979). However, there is no ridge feature south of the Central Basin Ridge ("Fault") which could represent a remnant arc or rifted counterpart of the Oki-Daito Ridge and which would allow for the West Philippine Basin to have formed by back-arc spreading behind the Oki-Daito Ridge during the early Tertiary (Karig, 1975). Scott et al. (1980) have also pointed out that there is no positive evidence from DSDP Holes 294 and 295 that the OkiDaito Ridge was an active arc during the early Tertiary. Nor indeed do DSDP Sites 445 and 446, close to the Oki-Daito Ridge, record any evidence for arc activity as long ago as the early Eocene (Klein, Kobayashi, et al., 1980). Scott et al. (1980) note that the 6000-meter water depth in the West Philippine Sea is deeper than that for normal ocean crust of early Tertiary age as predicted by the depth-time curve but does appear to fit the depthtime relationship of back-arc basin crust (Sclater et al., 1976). Evidence for the nature of the West Philippine Sea is therefore conflicting.

Site 447 , in the eastern part of the basin, lies between the Central Basin Ridge and the Palau-Kyushu Ridge. Paleontological evidence from the basal breccias suggests an age of 32-34 m.y. (Kroenke, Scott, et al., 1980), although the magnetic lineation patterns indicate an age at least 4 m.y. older; there may thus be an appreciable erosion surface between the breccias and the basaltic basement. These breccias are overlain by over 60 meters of middle to upper Oligocene tuffs and polymict breccias representing a volcaniclastic apron derived from the Palau-Kyushu Ridge. The mineralogy, petrology, and geochemistry of Site 447 basalts have been described by Mattey et al. (1980) and Wood, Mattey et al. (1980). They recognize two distinct magma types with different major element glass compositions and with different trace element ratios (e.g., $\mathrm{Ti} / \mathrm{Zr}, \mathrm{Y} / \mathrm{Zr}$ ) which appear to have evolved in separate magma chambers but nevertheless must have existed simultaneously in order to account for the observed downhole chemical variations. Each magma chamber was periodically replenished with a porphyritic primitive magma and underwent mixing followed by variable degrees of fractional crystallization prior to eruption. However, the overall geochemical characteristics of these basalts-low $\mathrm{K}, \mathrm{Rb}, \mathrm{Ba}, \mathrm{Sr}$, low $\mathrm{Nb}$ and $\mathrm{Ta}$, variable light REE depletion, and low ${ }^{87} \mathrm{Sr} /$ ${ }^{86} \mathrm{Sr}$ ratios ( 0.7026; Armstrong and Nixon, 1980)-are essentially similar to normal MORB. Abundances of iron as $\mathrm{FeO}^{*}$ and $\mathrm{Al}_{2} \mathrm{O}_{3}$ resemble those of MORB rather than back-arc basin basalts, using criteria established by Fryer et al. (this volume). There are thus no obvious arcrelated geochemical characteristics in Site 447 basalts such as have been found in some other marginal basins (cf. Tarney et al., 1981; Saunders et al., 1980). There is therefore no a priori reason to invoke back-arc spreading for the formation of the West Philippine Sea, although such an origin is by no means excluded.

Basalts recovered from Site 446 in the Daito Basin, between the Daito and Oki-Daito ridges (Fig. 1), are very different from those at Site 447 . They occur as a series of sills of post-early Eocene age (Marsh et al., 1980). There are two distinct types of basalt, one rich in 
kaersutitic hornblende, the other hornblende-free. Both types have strikingly high contents of titanium (up to $4.9 \% \mathrm{TiO}_{2}$ ) and incompatible elements as well as relatively strongly fractionated REE patterns $\left(\mathrm{Ce}_{\mathrm{N}} / \mathrm{Yb}_{\mathrm{N}}\right.$ $\sim 3-6)$. $\mathrm{Zr} / \mathrm{Nb}$ ratios are low $(<10)$ but $\mathrm{K} / \mathrm{Rb}$ ratios high. Many of the basalts are fairly iron-rich, but some are also $\mathrm{Mg}$-rich $(\sim 15 \% \mathrm{MgO})$; although the latter may have high $\mathrm{MgO}$ contents as a result of intrasill fractionation, they are still markedly enriched in incompatible trace elements. The basalts are tholeiitic or mildly alkaline. Their geochemical features are not unlike "enriched" MORB from Iceland or from $45^{\circ} \mathrm{N}$ on the MidAtlantic Ridge (Wood et al., 1979; Tarney et al., 1979) although the latter are not Ti-rich. They are an unusual suite of rocks. Their high $\mathrm{Nb}$ and Ta contents (Marsh et al., 1980; Wood, Mattey et al., 1980) contrast with the low $\mathrm{Nb}$ and $\mathrm{Ta}$ contents of almost all arc lavas and indeed with all marginal basin basalts so far described. Even the mildly alkaline lavas of Penguin volcano in Bransfield Strait marginal basin, next to the Antarctic Peninsula, for instance, have very low $\mathrm{Nb}$ contents and high $\mathrm{Zr} / \mathrm{Nb}$ ratios (Weaver et al., 1979).

It is clear that in their high concentration of $\mathrm{Ti}, \mathrm{Nb}$, and Ta these Site 446 lavas have no arc-related geochemical characteristics. The basement age at this site (53 m.y., Klein, Kobayashi et al., 1980) of course predates the development of the Palau-Kyushu Arc. Whereas the petrogenesis of the Site 446 lavas must remain enigmatic, it is evident that there is no basis for linking them in any way to back-arc spreading. It seems more likely, all evidence considered, that the West Philippine Sea is a "trapped" marginal basin unconnected with back-arc spreading in the strict sense.

If, as has been suggested, the Palau-Kyushu Ridge marks the site of an earlier N-S transform which became a convergent plate boundary coincident with the change in direction of Pacific plate motion approximately $45 \mathrm{Ma}$, the presence of the spreading center with its buoyant hot mantle on the western side of the transform would certainly have facilitated subduction of the cooler Pacific lithosphere on the eastern side of the transform.

\section{The Palau-Kyushu Ridge}

The Palau-Kyushu Ridge is over 2000 km long (Fig. 1) and rises to over 2000 meters above the adjacent basin floors. At Site 448 , over 600 meters of volcanic basement consisting of lava flows, dykes, and sills interbedded with volcaniclastic breccias were penetrated below middle Oligocene oozes. Like the dredged samples from this locality (Anonymous, 1977), the basalts are frequently highly vesicular, suggesting eruption at relatively shallow depths or even subaerially. These permeable rocks have been rather readily altered (Mattey et al., 1980), with the clay mineral alteration products being kaolin-rich in the upper part of the core but with mixed-layer smectite-vermiculite-chlorite clays deeper in the section (Aldrich et al., 1980). Nonetheless, the essential geochemical characteristics have been preserved. Nannofossil assemblages and ${ }^{40} \mathrm{Ar} /{ }^{39} \mathrm{Ar}$ dates indicate that the main period of volcanism began to fade about
$32 \mathrm{Ma}$ and had ceased altogether by $29 \mathrm{Ma}$ (Scott et al., 1980). Assuming contemporaneity with the fore-arc lavas on Saipan and Guam, which have yielded ages of approximately $42 \mathrm{~m} . \mathrm{y}$. (cf. Ingle, 1975) it would appear that volcanism on the Palau-Kyushu Ridge spanned a period of about $10 \mathrm{~m} . \mathrm{y}$. and began within a few million years after the start of subduction.

The geochemical characteristics of the Site 448 lavas has been described by Mattey et al. (1980) and Wood, Mattey et al. (1980). Almost all the lavas are basaltic and conform to the island arc tholeiite series of Jakeŝ and Gill (1970). They are readily distinguished from the basalts of the adjacent marginal basins by their low $\mathrm{Cr}$ $(20-50 \mathrm{ppm})$ and $\mathrm{Ni}(0-20 \mathrm{ppm})$ contents.

The Palau-Kyushu lavas are quartz-normative tholeiites and basaltic andesites with $48-56 \% \mathrm{SiO}_{2}, 13-17 \%$ $\mathrm{Al}_{2} \mathrm{O}_{3}$, and $10-15 \%$ iron as total $\mathrm{FeO}$. $\mathrm{FeO} / \mathrm{MgO}$ ratios range from 1.5 to over 4.0 , much higher than in the basin basalts, implying that they may have undergone considerable crystal fractionation. Currently popular models for the island arc tholeiite series invoke hydrous melting of the mantle wedge above the subducting slab with considerable crystal fractionation during ascent to explain the wide range of $\mathrm{Fe} / \mathrm{Mg}$ ratios and low $\mathrm{Cr}$ and Ni contents. Arc tholeiites from the Palau-Kyushu Ridge have similar geochemical characteristics to those from the Mariana fore-arc (Site 458 and 459) but include more iron-rich compositions. Mattey et al. (1980) noted, however, that the concentrations of many incompatible elements in the Palau-Kyushu lavas, especially the REE, ZR, Nb, and Ta, were much lower than in MORB with equivalent $\mathrm{Fe} / \mathrm{Mg}$ ratios, and that these did not increase systematically with $\mathrm{Fe} / \mathrm{Mg}$ ratio. Moreover, they distinguished several petrographic types (olplag, opx-cpx-plag, and cpx-plag phyric) that could not be related to each other by fractional crystallization. Thus either several distinct magma chambers were feeding lavas to the Palau-Kyushu Arc or the lavas were closer to "primary" melt compositions than has hitherto been admitted. The only source able to produce such iron-rich compositions would be the subducted ocean crust itself. Although thermal models for steady-state subduction zones (Anderson et al., 1976) tend not to favor melting of the subducted ocean crust, it is to be remembered that the Palau-Kyushu Arc developed rapidly following the start of subduction beneath the West Philippine Sea. Under such conditions high degrees of melting of ocean crust may have been possible. This would account for the consistently high $\mathrm{Fe} / \mathrm{Mg}$ ratios and low $\mathrm{Cr}$ and $\mathrm{Ni}$ contents of the arc tholeiites. In many respects the arc tholeiites resemble normal MORB in their trace element characteristics but tend to have rather high LIL element contents, as is typical of most subduction zone magmas.

\section{West Mariana Ridge}

The West Mariana Ridge (Fig. 1) is shallower than the Palau-Kyushu Ridge, usually less than 2000 meters below sea level. Drilling at Site 451 penetrated 930 meters of volcaniclastic material, the breccia fragments being composed mainly of basalts and basaltic andesites with 
rare andesites and having phenocrysts of plagioclase \pm clinopyroxene \pm orthopyroxene \pm olivine \pm magnetite (Mattey et al., 1980; Ishii, 1980).

Chemically these lavas have low contents of $\mathrm{Cr}, \mathrm{Ni}$, $\mathrm{Zr}, \mathrm{Nb}$, and $\mathrm{Ta}$, like the Palau-Kyushu arc tholeiites, but have low $\mathrm{Fe} / \mathrm{Mg}$ ratios (1.0-2.0), are lower in both $\mathrm{FeO}$ and $\mathrm{MgO}$, have much higher $\mathrm{Al}_{2} \mathrm{O}_{3}(18-20 \%)$ and $\mathrm{CaO}(9-13 \%)$, and a wider range of $\mathrm{SiO}_{2}(45-58 \%)$. There are larger trace element differences. $\mathrm{La} / \mathrm{Zr}$ and $\mathrm{Ce} / \mathrm{Zr}$ ratios are higher and REE patterns are more fractionated, with $\mathrm{Ce}_{\mathrm{N}} / \mathrm{Yb}_{\mathrm{N}} \sim 2$. Concentrations of $\mathrm{Ba}(110-$ $450 \mathrm{ppm})$ and $\mathrm{Sr}(450-600 \mathrm{ppm})$ and other LIL elements are notably higher than in arc tholeiites or in normal MORB. These characteristics are those of calc-alkalic magmas, even though most of the lavas are still basaltic in terms of major elements. Essentially similar, although metamorphosed, rock types were cored at Site 453 during Leg 60 but include cumulus gabbros as well.

\section{Distribution of Mariana Arc Magma Series in Time and Space}

In order to summarize the petrologic history of the Mariana arc, it is important to establish as carefully as possible the various igneous rock series present on each structural component of the arc system, including the islands which we have not yet discussed. Each of the three arc magma series-boninites, arc tholeiites, and calc-alkalic lavas-can be identified on the basis of major oxide chemistry, trace elements, and isotopic geochemistry and mineralogy. Boninite series lavas are particularly distinctive chemically and petrographically, and there is consequently little uncertain about their identification. The distinction between island arc tholeiites and calc-alkalic lavas is based increasingly on trace elements, although historically the contrasting degree of iron enrichment between the two has served as the basis for classification and been the starting pont for much speculation and experimental study. The original definition for calc-alkalic lavas was based on Peacock's (1931) alkali-lime index (the value of $\mathrm{SiO}_{2}$ in a differentiation series in which total $\mathrm{Na}_{2} \mathrm{O}+\mathrm{K}_{2} \mathrm{O}=\mathrm{CaO}$ ). But this is not strictly appropriate for most Mariana arc suites containing andesites (they turn out to be calcic rather than calc-alkalic), and has been largely superseded in contemporary petrological thought by the general idea that island arc andesites which show considerable iron enrichment belong to the island arc tholeiite series (e.g., Kuno, 1968; Jakeŝ and Gill, 1970; Miyashiro, 1974).

Mattey et al. (1980) and Wood et al. (this volume) have coupled this generalized definition with trace element data, noting that calc-alkalic lavas have considerably higher abundances of the mobile hygromagmatophile (HYG) elements than island arc tholeiites. They employ a ternary plot of $\mathrm{Th}-\mathrm{Ta}-\mathrm{Hf} / 3$ as a discriminant. On such a plot (Fig. 10) the calc-alkalic lavas of the Mariana arc system are considerably closer to the Th apex than arc tholeiites, and both suites are considerably depleted in Ta relative to MORB. On the basis of this and other discriminant diagrams, Wood et al. (this volume) propose that the earliest stages of Mariana arc volcanism are represented by arc tholeiites, whereas younger lavas in the system are calc-alkalic in composition. That is, considering only data for drill sites, the ancestral Mariana arc, which included the present forearc region and the Palau-Kyushu Ridge, had arc tholeiite compositions. The younger West Mariana Ridge and the modern arc, each formed after episodes of back-arc basin spreading, have calc-alkalic compositions. Since each of the successive arcs occupied the same structural position with respect to the fore-arc when they were active, Wood et al. (this volume) infer that much the same zone of mantle was tapped in each case. The transition from arc tholeiite to calc-alkalic compositions therefore reflects a fundamental change in mantle source compositions with time-specifically, steady addition of mobile HYG elements to it, derived from the subducting lithosphere.

In terms of iron enrichment, however, this transition was not so straightforward. On Figure 11A, the average compositions for the fore-arc lava types of Holes 458 and 459B (from Table 2) are plotted as well as data fields for samples from Hole 448 on the Palau-Kyushu Ridge and Hole 451 on the West Mariana Ridge (Mattey et al., 1980). A separate, more restricted field for Hole 448 glasses indicates that many of the lavas there have lost iron and gained magnesium as a result of alteration (Scott, 1980), thus suppressing the original iron enrichment and distorting the data field shown on Figure 11A. Similar effects may have occurred in fore-arc Holes 458 and 459B, but our earlier consideration of Figures 8 and 9 suggests that petrological processes (fractionation of titanomagnetite, different source compositions) rather than alteration prevented significant iron enrichment in those basalts. Still, iron enrichment is evident in some of them, and it is probably fair to describe them as arc tholeiites, even though they are not as iron-enriched as the Hole 448 glasses.

Figure 11B compares lavas of the Eocene Alutom and Miocene Umatak formations of Guam (Stark, 1963) and the Eocene Aimeliik formation of Palau (Mason et al., 1956). The data fields for Holes 448 and 451 are again shown. As discussed earlier, some of the Umatak Formation lavas are boninites. The suite from Palau shows so little iron enrichment that it resembles the classical calc-alkalic Cascades suite (Daly, 1933; Smith and Carmichael, 1968). There is somewhat more iron enrichment in the Umatak Formation, but it is not as extreme as in Hole 448 glasses and appears to straddle the field of calc-alkalic Hole 451 lavas. Figure 11C shows data for Eocene lavas of Saipan, which also have minimal iron enrichment.

Data for the present Mariana arc are depicted on Figure 11D. As noted by Dixon and Batiza (1979) and Stern (1979), the extent of iron enrichment is somewhat variable in the different volcanoes of the modern arc, with some islands, such as Sarigan, which have lavas closely resembling the classical calc-alkalic trend and others, such as Agrigan, having somewhat more iron enrichment.

Finally, all these trends can be compared with the compositions of volcanic glasses derived as ash from the 


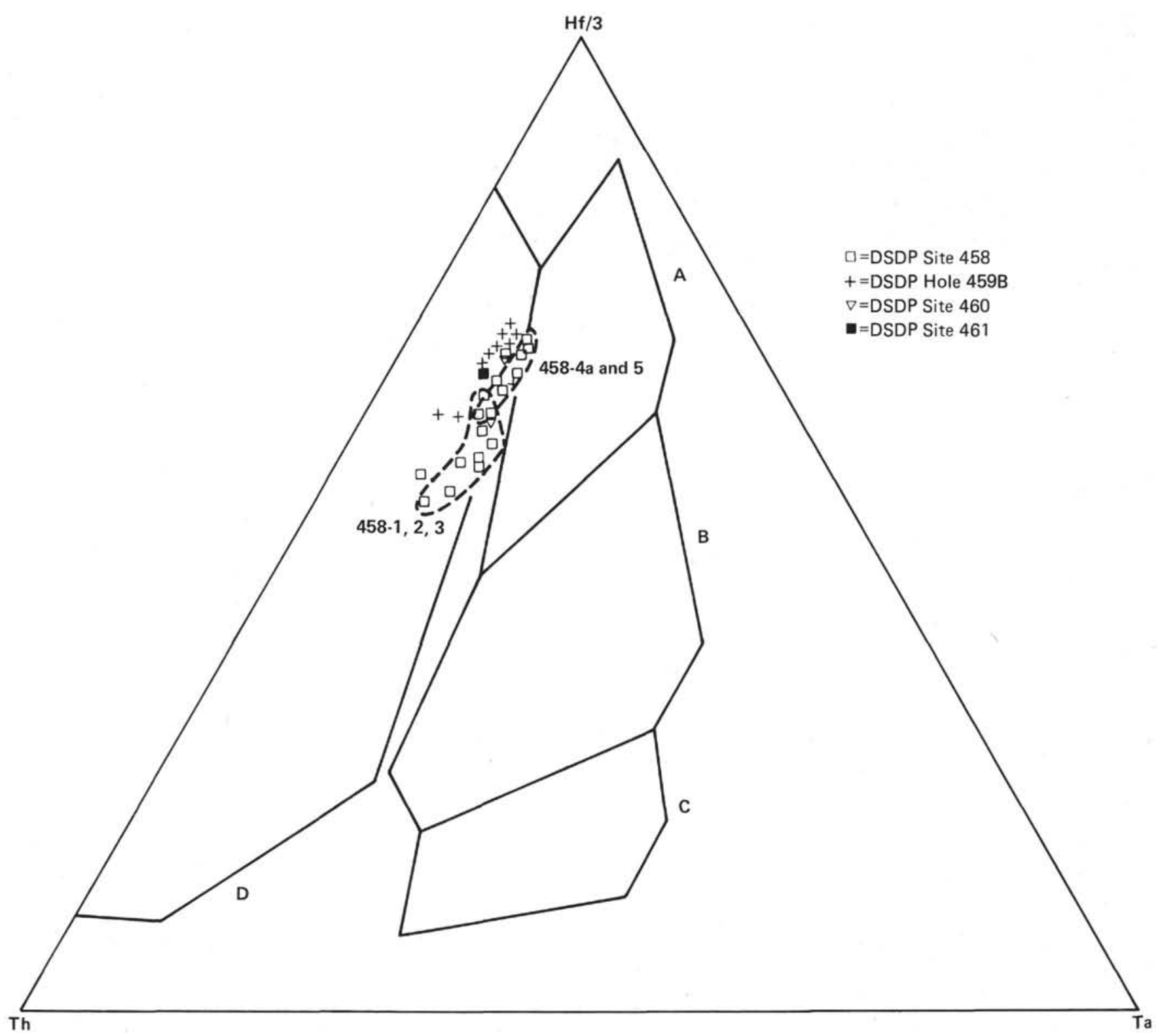

Figure 10. Ternary Ta-Th-Hf/3 diagram for island arc tholeiites and boninites from Holes 458, 459B, 460, and 461 (from Wood et al., this volume). Areas: $\mathrm{A}=\mathrm{N}$-type MORB; $\mathrm{B}=\mathrm{E}$-type MORB; $\mathrm{C}=$ within-plate lavas; $\mathrm{D}=$ active plate-margin lavas.

modern arc and deposited as turbidites at Site 453 (Figure 11E, from Packham and Williams, this volume). Many of these glasses show considerable enrichment compared with lavas of the modern arc. Since they also have low $\mathrm{TiO}_{2}$, Packham and Williams describe them as arc tholeiites and note that they erupted from at least $5 \mathrm{Ma}$ to about $200,000 \mathrm{y}$. ago. The present-day calcalkalic suites on the modern arc, which show so little iron enrichment, represent a distinct shift in the compositions of lavas erupted on these volcanoes.

The plots of Figure 11 show that eruption of calcalkalic lavas (those having little or no iron enrichment) and arc tholeiite sequences (with considerable iron enrichment) have varied in time and space in the Mariana arc. This is summarized in Table 4. The ancestral Eocene arc, which included the fore-arc region, Guam, and
Saipan structurally united with Palau and the PalauKyushu Ridge, consists of all three major arc rock suites-boninites, arc tholeiites, and calc-alkalic lavas. The Miocene arc, formed after the opening of the Parece-Vela Basin, consists of boninites and calc-alkalic lavas. On Guam these evidently represent a portion of the West Mariana Ridge left behind following opening of the Mariana Trough. The modern arc, which was formed after the opening of the Trough, evidently shifted from arc tholeiite to calc-alkalic compositions in the past $200,000 \mathrm{y}$.

The question presents itself whether the Eocene calcalkalic exposures on Guam, Saipan, and Palau have the same trace element characteristics as their younger counterparts on the West Mariana Ridge. Unfortunately, there are no data for the critical trace element discrimi- 


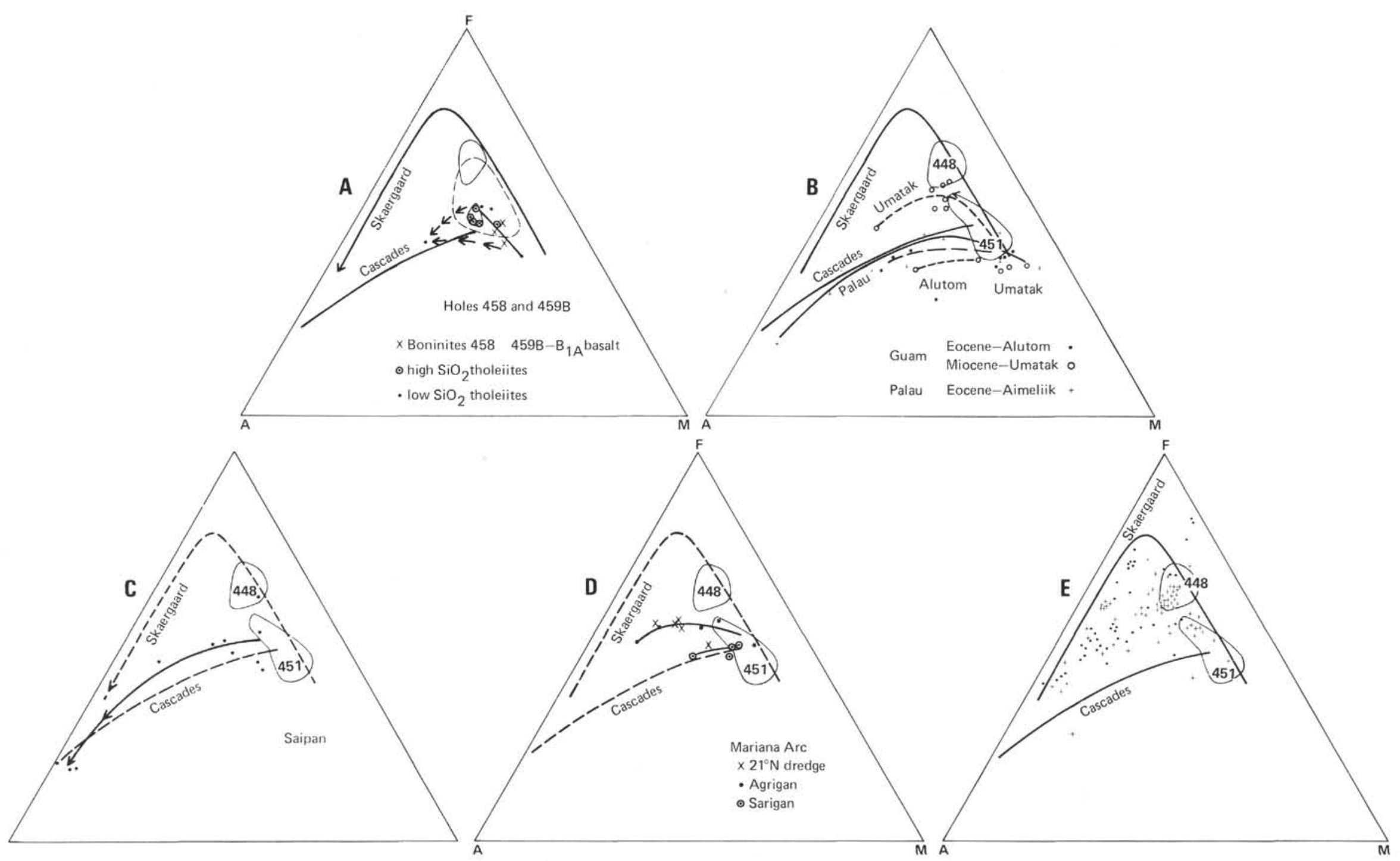

Figure 11. AFM $\left(\mathrm{Na}_{2} \mathrm{O}+\mathrm{K}_{2} \mathrm{O}-\mathrm{FeO} *-\mathrm{MgO}\right)$ ternary diagrams for tholeites and calc-alkalic lavas of the Mariana arc system. All diagrams show Skaergaard iron enrichment and Cascades calc-alkalic fractionation trends. A. Holes 458 and 459B, with symbols and groupings as in Figure 8A. (Closed field is Hole 448 glass compositions [Scott, 1980 ]; dashed field is Hole 448 fresh and altered basalt compositions [Mattey et al., 1980].) B. Eocene and Miocene lavas from Guam (Stark, 1963) and Palau (Mason et al., 1956) compared with fields for Eocene arc tholeiite glasses, Hole 448, Palau-Kyushu Ridge, and Miocene calc-alkalic basalts and andesites, Hole 451, West Mariana Ridge (Mattey et al., 1980). C. Eocene lavas from Saipan (Schmidt, 1957) compared with data fields for Hole 448 glasses and Hole 451 basalts and andesites. D. Modern Mariana arc lavas compared with data fields for Holes 448 and 451 samples. Data for Agrigan are from Stern (1979), for Sarigan, from Dixon and Batiza (1979), and for $21^{\circ} \mathrm{N}$ dredge haul from Wood et al. (this volume). E. Glass compositions from Hole 453 vitric tuffs derived from the Mariana arc prior to $200,000 \mathrm{y}$, ago, after Packham and Williams (this volume). Symbols are as in their fig. 5 . 
Table 4. Known distribution of igneous rock series in the Mariana arc system.

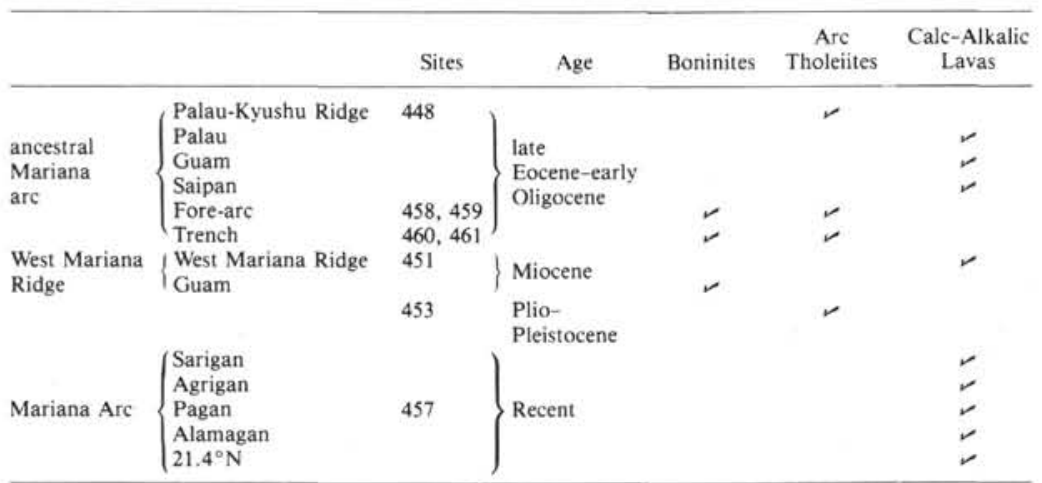

Note: Contrasts between arc tholeiites and calc-alkalic lavas here are based only on the degree of iron enrichment in differentiation series, not to differences in trace element abundances or to parental magma compositions. See text and Figure 11 for discussion.

nants ( $\mathrm{Ta}, \mathrm{Th}, \mathrm{Hf}, \mathrm{Nb}$, etc.) in lavas from these islands. There is some suggestion in the major oxide data, however, that they would not be as enriched in these elements as the younger Mariana arc calc-alkalic suites. We mentioned earlier the high alkali-lime indices of Mariana arc lavas in general, which technically classify most of them as calcic rather than calc-alkalic in composition. They are especially high for these older lavas (Table 4) because of their low total alkalis and, especially, their low $\mathrm{K}_{2} \mathrm{O}$. There are semiquantitative spectrographic trace element data for some Guam lavas (Tracey and Stark, 1963) which show low $\mathrm{Zr}$ and consistently lower $\mathrm{Ba}$ in Eocene Alutom lavas than in Miocene Umatak Formation lavas. Along the presently active arc, there are considerable variations in $\mathrm{K}_{2} \mathrm{O}$ and related trace elements, contributing to differences in the alkali-lime index, even though all the modern arc volcanoes are considered to be calc-alkalic in their general characteristics (Dixon and Batiza, 1979). We therefore conclude that there are variable enrichments in HYG element abundances in Eocene and modern Mariana arc calc-alkalic rock suites, with the younger lavas more enriched than the older. The development of calc-alkalic differentiation sequences does not seem to be entirely dependent on this aspect of their chemistry. The conclusion of Wood et al. (this volume) regarding steady enrichment of mantle sources in the mobile HYG elements may still be valid, although we need the relevant trace element data on samples from Guam, Saipan, and Palau to confirm this.

\section{Origin of Calc-Alkalic Magmas in the Mariana Arc System}

The origin of andesites and the calc-alkalic magma series remains a major petrogenetic problem. Two aspects of this problem stand out in the context of the Mariana arc: the role of fractional crystallization and the question of whether calc-alkalic lavas represent some sort of evolutionary sequence following island arc tholeiites in time and space.

Andesites and other siliceous lavas are subordinate in volume to basalts in much of the Mariana arc (Larson et al., 1974). Of the islands discussed earlier, only Saipan has a dearth of basalts. Where basalts are abundant, fractional crystallization tends to become an attractive hypothesis, especially where quantitative modeling supports it. This is the case for the Recent Mariana volcanoes (Stern, 1979; Dixon and Batiza, 1979). Stark (1963) also favored a fractional crystallization mechanism for each of the two sequences (Alutom and Umatak) of Guam. Only Schmidt (1957) expressed reservations about the efficacy of fractional crystallization in producing the dacites of Saipan.

Stern (1979) has provided more than the usual range of evidence in support of calc-alkalic fractional crystallization as the origin of the andesites of Agrigan volcano. His study included detailed examination of cumulus gabbros found as xenoliths in the lavas. The xenoliths matched the compositions of a gabbroic mass he calculated to underlie the volcano at depths of less than $5 \mathrm{~km}$. Similar gabbros were recovered in great abundance in association with calc-alkalic metavolcanic rocks derived from the West Mariana Ridge in Hole 453 during Leg 60. In Part I we summarized evidence that the Agrigan xenoliths and Hole $\mathbf{4 5 3}$ gabbros are among a class of gabbros uniquely suited to be the cumulus residua of calc-alkalic fractionation. They have extremely calcic plagioclase, with resulting low whole-rock $\mathrm{SiO}_{2}$, and crystallized at high $\mathrm{P}\left(\mathrm{H}_{2} \mathrm{O}\right)$, as indicated by their mineralogy. Fractionation of such mineral assemblages in the proportions seen in the gabbros would lead to significant enrichment in $\mathrm{SiO}_{2}$ with little change in $\mathrm{FeO}^{*} / \mathrm{MgO}$ (the calc-alkalic trend).

From the occurrence of the gabbros in Hole 453, on Agrigan, and even, as argued earlier, south of Guam in the Mariana Trench (Dietrich et al., 1978), it seems evident that they are a major part of the deep crustal structure of the Mariana arc system. Such gabbros have been found in all three of the age-structural domains of the Mariana arc (Eocene, Miocene, and Recent), all of which have calc-alkalic volcanics (Table 4). This suggests that a similar type of fractional crystallization has been a major factor in the production of calc-alkalic andesites throughout the history of the arc.

Two contributors to this volume suggest that calcalkalic lavas follow extensive arc tholeiite volcanism in the Mariana arc system. Wood et al. view this as a general shift affecting the two younger arc ridges, as we 
have discussed, but it seems now that calc-alkalic lavas and their apparently complementary cumulus gabbros occurred much earlier in the history of the arc than suggested by DSDP data alone. Packham and Williams concern themselves only with the presently active arc and propose that the Recent calc-alkalic high volcanoes of the arc have followed arc tholeiite volcanoes which erupted over a much longer time span. Although there are inadequate age data to support it, it is possible that the high volcanoes of each of the older arcs also evolved from an arc tholeiite to a calc-alkalic stage. In the case of the Eocene arc complex, this is at least a spatial, if not a temporal, phenomenon. The subaerial and shallow submarine Eocene lavas of Guam and Saipan clearly erupted on structures higher than the pillow lavas at forearc Sites 458 and 459 and contrast with the latter in having calc-alkalic rather than arc tholeiite compositions. The data for the West Mariana Ridge are the least comprehensive, since calc-alkalic lavas only have been recovered from two closely spaced sites (451 and 453 ).

In terms of the fractional crystallization mechanism outlined here for producing Mariana arc calc-alkalic andesites (segregation of cumulus assemblages compaparable to Hole 453 gabbros and Agrigan xenoliths), a plausible evolutionary sequence can be proposed. The most important condition for such fractionation to occur is development of magma chambers in the deep crust at high water pressures. Gravity and seismic data demonstrate that the crust beneath the fore-arc region near Sites 458 and 459 is thin (LaTraille and Hussong, 1980; Hussong and Fryer, this volume). This is verified by the persistent recovery of ultramafic rocks at fairly shallow levels at many places in the Mariana Trench (Dietrich et al., 1978; S. Bloomer and J. Hawkins, personal communication). Fore-arc magma chambers thus were shallow, and the conditions of high $p\left(\mathrm{H}_{2} \mathrm{O}\right)$ required for calc-alkalic fractionation could not be achieved. Beneath lines of subaerial arc volcanoes, however, the crust is considerably thicker (see Plate 2 , back pocket, this volume; Hussong, this volume). The crust beneath each of the arcs must also have thickened with time. The coarse and highly porous pyroclastic ejecta of even basaltic island arc volcanoes guaranteed that considerable amounts of water were trapped within thickening lava piles. Even if the same magma chambers continued to exist, they had to become more deeply buried as the volcanoes built. There should thus have been a tendency for tholeiitic island arcs to develop conditions suitable to calc-alkalic magmatism. This need not have happened simultaneously along the length of the arcs, but ultimately it should have happened generally along all of them.

\section{Back-arc Basin Opening and Arc Volcanism}

Recovery of gabbros at Site 453 demonstrated that opening of the Mariana Trough split the West Mariana Ridge deep into its crustal roots. Solidified magma chambers were torn in two. There is no question that this must have profoundly affected arc volcanism. Scott et al. (1980) and Scott and Kroenke (1980) argue, on the basis of available radiometric and paleontologic data and on the occurrence of ash beds in sediments cored in the Parece Vela Basin, that arc volcanism waned considerably, or ceased altogether, with each opening of a back-arc basin in the Philippine Sea. Clearly, however, following opening of the Mariana Trough, arc volcanism soon resumed. Vitric turbidites derived from air-fall volcanic ash produced at the presently active Mariana arc have been deposited at Site 453 nearly continuously for the past 5 m.y. (Packham and Williams, this volume). Upper Miocene-lower Pliocene hiatuses in forearc Holes 458 and 459B (Kling, this volume; Ellis, this volume) suggest that the earlier stages of opening of the Mariana Trough were unaccompanied by arc volcanism. However, there is no corresponding upper Oligocenelower Miocene hiatus in Hole 459B for the opening of the Parece Vela Basin. Some ash was deposited in every core in this time interval, but since the sediments of Hole 459B are primarily turbidites, it is possible that erosion and sediment transport processes simply persisted throughout any interruption in volcanism on the arc.

Rodolfo and Warner (1980) suggest that the earliest stages of back-arc rifting consist of mixed basalt-andesite volcanism because emplacement of basaltic magmas in contact with water-saturated pyroclastic debris shed into the newly opened narrow rift. Once this happened, however, what were the compositions of the earliest lavas to erupt along the new arcs? Packham and Williams (this volume) think that the compositions of the Mariana arc and Mariana Trough lavas have diverged in the past $5.0 \mathrm{~m} . \mathrm{y}$. from a single basaltic composition resembling Trough basalts. This makes sense in that the magma sources for the present Trough and arc are still quite close together (approx. $120 \mathrm{~km}$ ) and probably were only a few tens of kilometers apart when the line of the arc first became well established. Wood et al. (this volume) and Fryer et al. (this volume), however, note that basalts in the Trough have some of the geochemical characteristics of arc lavas, notably enrichments in some of the mobile HYG elements. In the earliest stages of rifting, such enrichments might have been caused either by contamination (e.g., Rodolfo and Warner, 1980) or by HYG-element enrichments in the mantle source. Probably, therefore, the initial arc and Trough lavas were similar but had compositions in between what we recognize as modern arc and Trough basalts. The early proximity of arc and Trough magma sources almost certainly means that arc lavas were then even more dominated by basalts than now. This is borne out for the West Mariana Ridge by an increase in the abundance of andesitic ash and a decrease in hyaloclastic basalt at Parece Vela Basin Site 450 as the basin widened in the Miocene (Rodolfo and Warner, 1980).

From these considerations, it would seem that for calc-alkalic magmatism to have occurred on either the West Mariana Ridge or the Mariana arc, it must have followed greater or lesser outpourings of basalts. With the Trough opening so close to the arc, geothermal gradients beneath the arc, too, would have been steeper and the depth of origin of arc basalts correspondingly shallower. Conditions were favorable to the development of 
shallow magma chambers in which iron enrichment fractionation would have occurred. This would have been essentially arc tholeiite magmatism. As the thermal regimes responsible for volcanism along the arc and in the center of the Trough separated, the sources of arc magmas should have deepened, eruption rates diminished, the crust of the arc thickened, and the conditions for calc-alkalic gabbro fractionation approached. A similar sequence should also have occurred on the West Mariana Ridge, following opening of the Parece Vela Basin.

\section{Formation of Back-arc Basins}

Plate tectonic theory has had considerable success in accounting for the principal physiographic features of the ocean floor and the ages of different portions of the ocean crust. One of the great tasks remaining before a comprehensive global tectonic synthesis is achieved is to account for the tremendous quantity and variety of igneous activity and lava types at both accretionary and convergent plate boundaries. Back-arc basins are a particularly complex problem because they form in the midst of the principal physical manifestations of volcanism at convergent plate boundaries, the island arcs. Since we are far from understanding the laws which govern the placement and perpetuation of spreading centers in the ocean basins, these interarc basins would seemingly be even more difficult to explain.

The principal hypotheses to date that account for back-arc basins have their considerable parallels in the original hypotheses of seafloor spreading and plate tectonics-viz., the two-limbed convection model of Hess (1962) and, alternatively; the recognition that spreading centers are not directly linked to such a simple system but respond more or less passively either to larger patterns of convection in the mantle or perhaps to the motions of the larger plates (e.g., McKenzie, 1967, 1969). Thus Karig's (1971b) original back-arc basin hypothesis was that a "diapir" of mantle material rose from the subducting lithospheric plate to sunder the arcs and initiate spreading basins by a type of shallow two-limbed convection. Karig supposed that frictional heating at the subduction zone (Oxburgh and Turcotte, 1970) caused the diapir, but more recent models propose simply that subduction drags mantle material downward, forcing convective turnover behind the arc and producing tension and back-arc rifting (Sleep and Toksöz, 1971; Andrews and Sleep, 1973; Toksöz and Bird, 1977; Toksöz and Hsui, 1978). Bibee et al. (1980) have extended Karig's hypothesis to explain apparently asymmetric spreading and ridge crest jumps in the Mariana Trough. These keep the center of spreading close to the Mariana arc above the subduction-triggered diapir. Uyeda and Kanamori (1979), however, argue that wesstern Pacific back-arc spreading occurs in response to retreat of the Eurasian plate from the Pacific plate, which establishes a dominantly tensional stress regime in such regions as the Philippine Sea, allowing back-arc basins to form without the formation of a mantle diapir. There are similar proposals by Chase (1978) and Jurdy (1979).
Any one of these hypotheses can explain how the Mariana arc has twice been split by back-arc basins. The diapiric model does not allow the locus of back-arc spreading to shift too far to the west of the arc and away from the subduction zone. Episodically, a major ridgecrest jump to a position within the arc itself must occur for the zone of rifting to remain centered on the mantle diapir. Toksöz and Hsui (1978) argue that back-arc spreading actually forces the arc against the subducting plate, decreasing its dip and ultimately making overturn of the mantle caused by subduction impossible. Backarc spreading ceases, the steep dip of the subduction zone is gradually restored, and a new cycle begins. According to the passive spreading model, periods of retreat of the Eurasian plate from the Pacific plate may alternate with periods of relative convergence in which back-arc spreading ceases, so that the two halves of back-arc lithosphere combine into a single "welded" plate. Renewed tensional stress will initiate a new rift along the weakest line of the combined plate. In the absence of an active back-arc spreading center, this is believed by Uyeda (personal communication) to be the line of the arc.

Petrological data presently do little to constrain these hypotheses inasmuch as our understanding of the origin of island arc lavas is sufficiently ambiguous to allow virtually any combination of petrological and tectonic speculation. The subduction zone drag model probably has the greatest difficulties from a petrological viewpoint since it places arc volcanism directly above the downwelling limb of the proposed convection cell, a difficulty recognized by Andrews and Sleep (1973) and Toksöz and Hsui (1978). The direct opposite is implied by petrological models requiring components from the subduction zone either to infiltrate or rise diapirically into the overlying mantle to become sources for arc lavas. Subduction zone drag offers no explanation for the source of heat to produce these lavas. Possibly, no specific addition of heat, produced for example by friction, is necessary. Dick (1980) argues that the high vesicularity of arc and back-arc basalts reflects addition of water to the mantle above the subducting slab. This lowers the solidus, produces melting (e.g., Wyllie, 1971; McBirney, 1965), and reduces mantle density (O'Hara, 1975), causing diapiric upwelling. Melting continues in the rising diapirs until the water-saturated solidus is reached at low pressures.

We have argued here generally in favor of segregation of island-arc-tholeiite, calc-alkalic, and olivine-boninite parental magams from the relatively shallow mantle beneath island arcs-i.e., not from the subducted slabin a manner consistent with Dick's hypothesis. There appears to be no way to distinguish on geochemical grounds whether the immediate mantle sources of the various magmas were originally directly beneath the arc or arose by some diapiric mechanism from the slab to the shallow levels where melt segregation took place. At most, we can infer only that the mobile HYG elements were derived from the subducting materials and infiltrated the shallow mantle beneath the arc, causing the 
particular enrichments in these elements observed to a greater or lesser degree in all the arc lavas. But whether or not the peridotite component of the magma sources was originally in place beneath the arcs, or rose from the depths, extraction of magmas and the development of a thick island arc lava pile would entail considerable accumulation beneath it of refractory peridotite depleted in basalt or basaltic-andesite fractions parental to arc lavas. Boninites themselves are evidence that just such depleted peridotite exists in reasonable abundance beneath the Mariana fore-arc region and the island of Guam.

We suggest that after sufficient accumulation of such shallow refractory peridotite beneath an island arc, it would become increasingly difficult to extract a melt fraction from it. With the building of high volcanoes, it would also become hydraulically more difficult for that melt fraction to reach the surface. Only the more volatile and explosive differentiated lavas would erupt. We can therefore surmise that conditions in the mantle itself would add to those previously described and favor a shift toward calc-alkalic compositions during the history of an island arc.

We now carry this one step further, to ask whether accumulation of such a refractory mass could also lead to the development of conditions favorable to the initiation of a new back-arc basin. Either some source of heat exists, related to subduction, that produces arc magmas, or, as Dick suggests, the mantle solidus is suppressed by addition of water, resulting in diapirism and melting. In either case, the effects should have become more or less continuous and involved the same zone of mantle to build three successive island arcs in the Marianas system. Volcanism itself represents release of energy, both thermal and gravitational (buoyant). One can readily suppose that as the mantle beneath each arc became steadily more refractory and less susceptible to having energy released from it by volcanism, the energy would manifest itself in other forms.

We suggest, then, that there may have been a type of petrological feedback mechanism in the Mariana arc system related to the long-continued build-up of arc magmas in restricted geographical areas. In appropriate conditions of tensional stress in the region, this feedback was manifested by major reorganizations of the mantle beneath the arcs, wherein the thick, refractory mantle that formed beneath them was split open and replaced by new depleted mantle. This became the source for both back-arc basin basalts and lavas of the new island arc (Fig. 12A). We see this simply as a consequence of buildup of heat and/or buoyant forces beneath thickening zones of mantle that were an increasing obstacle to release of either form of energy to the earth's surface by means of volcanism. With such a mechanism we would expect separate cycles of mantle enrichment in the mobile HYG elements corresponding to the building of each separate arc (Fig. 12B). For reasons given in this and earlier sections, these cycles would be superimposed on the evolution of each arc from arc tholeiite to calc-alkalic compositions.

With passive back-arc spreading models such as that of Uyeda and Kanamori (1979), there would be no necessary connection between the petrological state of development of an arc (or the mantle beneath it) and the cessation of back-arc spreading in one basin and its renewal in another. Any apparent arc petrologic sequence would be fortuitous. Conversely, lack of a consistent sequence might support such a model. There is potential difficulty, however, in providing a mechanism by which successive arcs are split precisely down their lengths in response to the motions of distant plates. Arc rifting involves stretching, thinning, and ultimately separating the arc crust along one of its thickest parts, tearing into deep, solidified crustal magma chambers. It is not obvious that this should be the weakest part of the crust, even granting a "welded" back-arc lithosphere. The mechanism proposed here does not depend so much on a "weak" zone of lithosphere as on a concentration of forces beneath the arcs to produce rifting. We believe that the calc-alkalic gabbros and metamorphic rocks of Hole 453 in the Mariana Trough, which crystallized and were metamorphosed at fairly substantial depths (5-10 $\mathrm{km}$ or more), indicating uplift, imply the action of buoyant forces during this mantle reorganization at the outset of rifting.

Uyeda and Kanamori (1979) attempt to account for voluminous calc-alkalic lavas in eastern Pacific arcs such as the Andes by proposing that a regional compressive stress pattern keeps back-arc basins from developing, preventing eruption of magmas derived at shallow levels in the mantle (i.e., basalts). If this is indeed the case, then one could as well say that the compressive regional stress regimes simply prevent basins from opening, whether or not there are diapirs. The arcs would be forced to stay near or above any zones of concentration of heat or buoyant forces. Since they would have to feed upon themselves for release of energy, voluminous calc-alkalic magmatism might be expected. A tensional regional stress pattern in the western Pacific may therefore contribute to the formation of back-arc basins but does not necessarily preclude convective disturbances in the mantle such as the one depicted in Figure 12. We point out that once the type of convective disturbance envisaged has occurred, new and fertile mantle sources are available for generation of both arc and back-arc basalts for some time to come, without any additional major overturn or counterflow of the mantle.

Future petrologic contributions to hypotheses of Mariana arc evolution and back-arc basin origin must focus on evaluation of the mantle sources of arc lavas, particularly those of the readily avalaible calc-alkalic suites of the older islands and of the earliest stages of volcanism on the presently active arc. The latter may be possible only with deep drilling on one of the modern volcanoes.

\section{ACKNOWLEDGMENTS}

We are grateful to the shipboard participants on Leg 60, particularly to Patricia Fryer, Arend Meijer, and Anatoly Sharaskin, whose contributions to this volume and conversations with us made this synthesis possible. We are also grateful to H. Dick, T. Ishii, N. Marsh, D. Mattey, R. Scott, and G. Zakariadze, whose cruise participation and data for Initial Reports Volumes 58 and 59 provided the petrologic context necessary for understanding Leg 60 results. The 


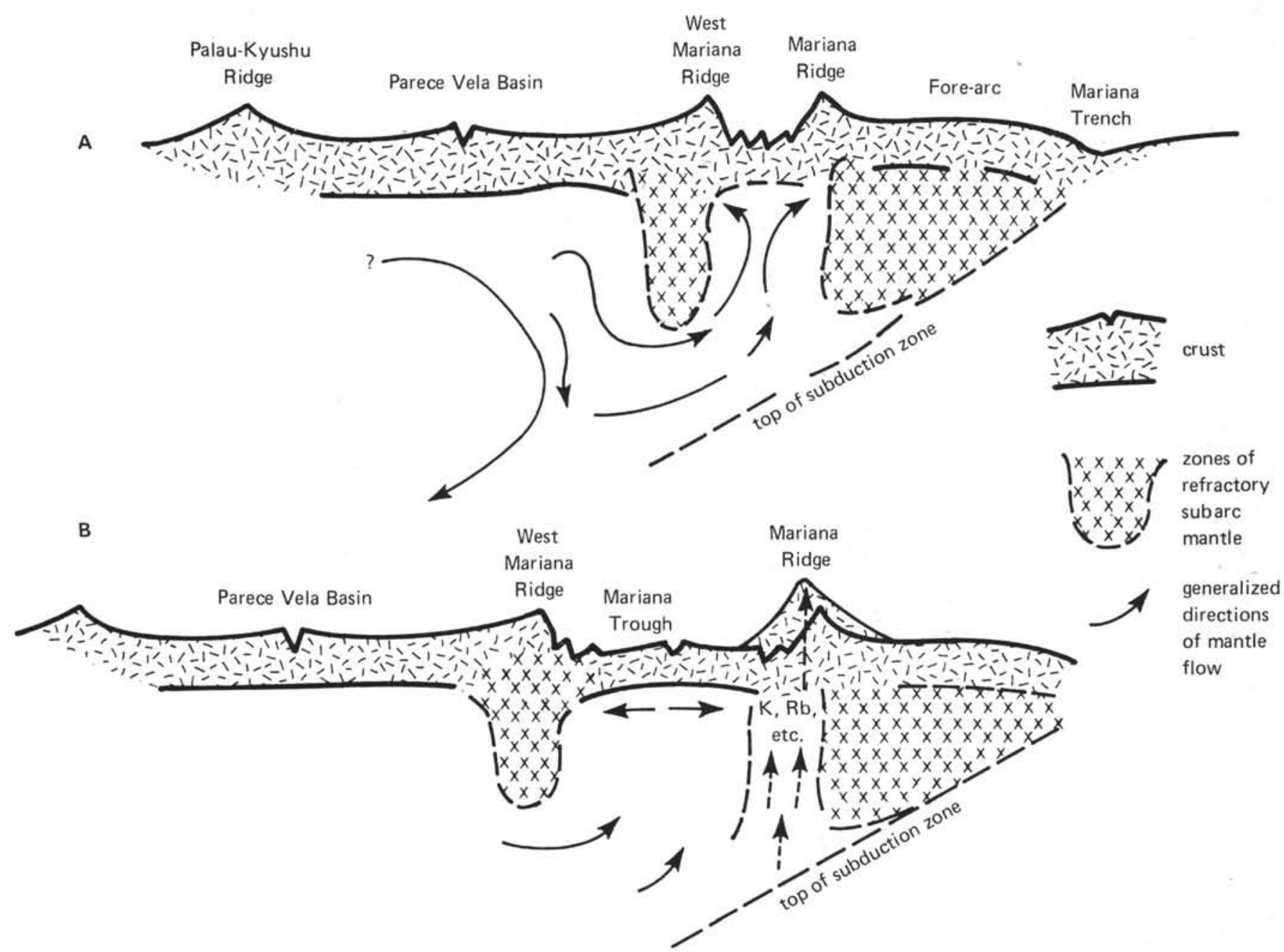

Figure 12. Suggested model for back-arc basin rifting using the Mariana Trough as an example. A. Disruption of refractory subarc mantle and introduction of new fertile mantle in its place. B. Continued back-arc spreading coupled with simultaneous modification of subarc mantle by (1) extraction of magmas at top and (2) addition of mobile HYG elements from below. Eventually (1) outstrips (2), resulting in refractory, infertile subarc mantle from which melts are difficult to extract, necessitating return to $\mathrm{A}$.

manuscript benefited from comments by S. Uyeda, S. Bloomer, T. Dixon, and J. Melchior and from discussions with J. W. Hawkins, Jr., and D. M. Hussong.

\section{REFERENCES}

Aldrich, J., Tieh, T., and Scott, R., 1980. Alteration of remnant arc debris, Site 448, Palau-Kyushu Ridge, Philippine Sea, Deep Sea Drilling Project Leg 59. In Kroenke, L., Scott, R., et al., Init. Repts. DSDP 59: Washington (U.S. Govt. Printing Office), 737-742.

Anderson, R. N., Uyeda, S., and Miyashiro, A., 1976. Geophysical and geochemical constraints at converging plate boundaries- $\mathrm{Pt}$. 1: Dehydration in the downgoing slab. Geophys. J. Roy. Astron. Soc., 44:333-357.

Andrews, D., and Sleep, N. H., 1973. Numerical modeling of tectonic flow behind island arcs. Geophys. J. Roy. Astron. Soc., 38: 237-251.

Andrews, J. E., 1980. Morphologic evidence for reorientation of seafloor spreading in the West Philippine Basin. Geology, 8:140-143.

Anonymous, 1977. Initial report of the geological study of oceanic crust of the Philippine Sea floor. Ofioliti, 2:137-168.

Arculus, R., and Wills, K., 1980. The petrology of plutonic blocks and inclusions from the Lesser Antilles Island arc. J. Petrol., 21:743-799.

Armstrong, R., and Nixon, G., 1980. Chemical and Sr-isotopic composition of igneous rocks from Deep Sea Drilling Project Legs 59 and 60. In Kroenke, L., Scott, R., et al., Init. Repts. DSDP, 59: Washington (U.S. Govt. Printing Office), 719-727.

Beccaluva, L., Macciotta, G., Savelli, C., et al., 1980. Geochemistry and $\mathrm{K} / \mathrm{Ar}$ ages of volcanics dredged in the Philippine Sea (Mariana, Yap, and Palau Trenches, and Parece Vela Basin). In Hayes, D. E. (Ed.), The Tectonic and Geologic Evolution of Southeast Asian Seas and Islands: Geophys. Monog. 23: Washington (American Geophysics Union), 247-268.

Ben-Avraham, Z., Bowin, C., and Segawa, T., 1972. An extinct spreading center in the Philippine Sea. Nature, 240:453-455.

Bender, J., Hodges, F., and Bence, A., 1978. Petrogenesis of basalts from the Project FAMOUS area: Experimental study from 0 to 15 kbars. Earth Planet. Sci. Lett., 41:277-302.

Bibee, L. D., Shor, G. G., Jr., and Lu, R. S., 1980. Inter-arc spreading in the Mariana Trough. Mar. Geol., 35:183-197.

Bloomer, S., Melchior, J., Poreda, R., et al., 1979. Mariana arctrench studies: petrology of boninites and evidence for a "boninite series." Eos, 60:968. (Abstract)

Bougault, H., Treuil, M., and Joron, J.L., 1978. Trace elements in basalts from $23^{\circ}$ and $36^{\circ}$ in the Atlantic Ocean: Fractional crystallization, partial melting, and heterogeneity of the upper mantle. In Melson, W. G., Rabinowitz, P. D., et al., Init. Repts. DSDP, 45: Washington (U.S. Govt. Printing Office), 493-506.

Cameron, W. E., Nisbet, E. G., and Dietrich, V. J., 1979. Boninites, komatiites, and ophiolitic basalts. Nature, 280:440-553. 
1980. Petrographic dissimilarities between ophiolitic and ocean-floor basalts. In Panyiotou, A. (Ed.), Ophiolites: Proceedings International Ophiolite Symposium Cyprus, 1979: Nicosia (Rep. Cyprus Min. Agric. Nat. Resources Geol. Surv. Dept.), pp. $182-192$.

Chase, C. G., 1978. Extension behind island arcs and motions relative to hotspots. J. Geophys. Res., 81:1916-1934.

Clague, D. A., and Bunch, T. E., 1976. Formation of ferrobasalt at east Pacific midocean spreading centers. J. Geophys. Res., 81: 4247-4256.

Coleman, R. G., 1977. Ophiolites: New York (Springer-Verlag).

Daly, R. A., 1933. Igneous Rocks and the Depths of the Earth: New York (Hafner, reprint 1968).

Dick, H. J. B., 1980. Vesicularity of Shikoku Basin basalt: A possible correlation with the anomalous depths of back-arc basins. In Klein, G. deV., Kobayashi, K., et al., Init. Repts. DSDP, 58: Washington (U.S. Govt. Printing Office), 895-904.

Dietrich, V., Emmermann, R., Oberhansli, R., et al., 1978. Geochemistry of basaltic and gabbroic rocks from the West Mariana basin and the Mariana Trench. Earth Planet. Sci. Lett., 39:127-144.

Dixon, T. H., and Batiza, R., 1979. Petrology and chemistry of Recent lavas in the northern Marianas: Implications for the origin of island arc basalts. Contrib. Mineral. Petrol., 70:156-181.

Duncan, R. A., and Green, D. H., 1980. The role of multistage melting in the formation of oceanic crust. Geology, 8:22-26.

Elders, W. A., Hoagland. J. R., McDowell, S. D., et al, 1979. Hydrothermal mineral zones in the geothermal reservoir of Cerro Prieto. In Elders, W. A. (Ed.), Geology and Geothermics of the Salton Trough, GSA Guidebook, U.C. Riverside Campus Museum Contrib., 5:36-43.

Ewart, A., Brothers, R. N., and Mateen, A., 1977. An outline of the geology and geochemistry and the possible petrogenetic evolution of the volcanic rocks of the Tonga-Kermadec-New Zealand island arc. J. Volcanol. Geotherm. Res., 2:205-250.

Fujii, T., Kushiro, 1., and Hamuro, K., 1978. Melting relations and viscosity of an abyssal olivine tholeiite. In Melson, W. G., Rabinowitz, P. D., et al., Init. Repts. DSDP, 45: Washington (U.S. Govt. Printing Office), 513-516.

Garcia, M. O., Liu, N. W. K., and Muenow, D. W., 1979. Volatiles in submarine volcanic rocks from the Mariana island arc and trough. Geochim. Cosmochim. Acta, 43:305-312.

Gass, I. G., 1963. Is the Troodos Massif of Cyprus a fragment of Mesozoic ocean floor? Nature, 220:39-42.

Green, D. H., 1973. Experimental melting studies on a model upper mantle composition at high pressure under water-saturated and water-undersaturated conditions. Earth Planet. Sci. Lett., 19: $37-53$.

1976. Experimental testing of "equilibrium" partial melting of peridotite under water-saturated, high-pressure conditions. Canadian Mineral., 14:255-268.

Hart, S. R., Glassley, W. E., and Karig, D. E., 1972. Basalts and seafloor spreading behind the Mariana island arc. Earth Planet. Sci. Lett., 15:12-18.

Hawkesworth, C., Norry, M., Roddick, J. C., et al., $1979 .{ }^{143} \mathrm{Nd} /$ ${ }^{144} \mathrm{Nd},{ }^{87} \mathrm{Sr} /{ }^{86} \mathrm{Sr}$, and incompatible element variations in calcalkaline andesites and plateau lavas from South America. Earth Planet. Sci. Lett., 42:45-57.

Hellman, P., and Green, T. H., 1979. The role of sphene as an accessory phase in the high pressure partial melting of hydrous mafic compositions. Earth Planet. Sci. Lett., 42:38-40.

Hess, H. H., 1962. History of ocean basins. In Engel, A. E. J., James, H. L., and Leonard, B. F. (Eds.), Petrological Studies: A Volume in Honor of A. F. Buddington: Boulder (Geological Society of America), pp. 599-620.

Hilde, T. W. C., Uyeda, S., and Kroenke, L., 1977. Evolution of the western Pacific and its margin. Tectonophysics, 38:145-165.

Hobart, M. A., Anderson, R. N., and Uyeda, S., 1979. Heat transfer in the Mariana Trough. Eos, 60:383. (Abstract)

Hsü, K. J., 1975. Catastrophic debris streams (sturtzstroms) generated by rockfalls. Geol. Soc. Am. Bull., 86:129-140.

Humphris, S. E., and Thompson, G., 1978. Hydrothermal alteration of oceanic basalts by seawater. Geochim. Cosmochim. Acta., 42: $127-136$

Ingle, J. C., Jr., 1975. Summary of Late Paleogene-Neogene insular stratigraphy, paleobathymetry and correlations, Philippine
Sea and Sea of Japan Region. In Karig, D. E., Ingle, J. C., et al., Init. Repts. DSDP, 31: Washington (U.S. Govt. Printing Office), $837-856$.

Ishii, T., 1980. Pyroxene geothermometry of basalts and an andesite from the Palau-Kyushu and West Mariana Ridges, Deep Sea Drilling Project Leg 59. In Kroenke, L., Scott, R., et al., Init. Repts. $D S D P, 59$ : Washington (U.S. Govt. Printing Office), 693-718.

Jakeŝ, P., and Gill, J., 1970. Rare earth elements and the island arc tholeiite series. Earth Planet. Sci. Lett., 9:17-28.

Jaques, A. L., and Green, D. H., 1980. Anhydrous melting of peridotite at $0-15 \mathrm{~kb}$ pressure and the genesis of tholeiitic basalts. Contrib. Mineral. Petrol., 73:287-310.

Jurdy, D. M., 1979. Relative plate motions and the formation of marginal basins. J. Geophys. Res., 84:6796-6802.

Karig, D. E., 1971a. Structural history of the Mariana Island arc system. Geol. Soc. Am. Bull., 82:323-344.

$1971 \mathrm{~b}$. Origin and development of marginal basins in the Western Pacific. J. Geophys. Res., 76:2542-2561.

1975. Basin genesis in the Philippine Sea. In Karig, D. E., Ingle, J. C., Jr., et al., Init. Repts. DSDP, 31: Washington (U.S. Govt. Printing Office), 857-879.

Karig, D. E., Ingle, J. C., Jr., et al., 1975. Init. Repts. DSDP, 31: Washington (U.S. Govt. Printing Office).

Kay, R. W., 1980. Volcanic arc magmas: Implications of a meltingmixing model for element recycling in the crust-upper mantle system. J. Geol., 88:497-522.

Kidd, R. G. W., 1977. A model for the process of formation of the upper oceanic crust. Geophys. J. Roy. Astron. Soc., 40:149-183.

Klein, G. deV., Kobayashi, K., et al., 1980. Init. Repts. DSDP, 58: Washington (U.S. Govt. Printing Office).

Kroenke, L., Scott, R., et al., 1980. Init. Repts. DSDP, 59: Washington (U.S. Govt. Printing Office).

Kuno, H., 1968. Differentiation of basalt magmas. In Hess, H. H., and Poldervaart, A. (Eds.), Basalts: the Poldervaart Treatise on Rocks of Basaltic Composition: New York (Interscience), pp. 623-688.

Kushiro, I., 1972. Effect of water on the compositions of magmas formed at high pressure. J. Petrol,, 13:311-334.

1973. Origin of some magmas in ocean and circum-oceanic regions. Tectonophysics, 17:211-222.

1974. Melting of hydrous upper mantle and possible generation of andesitic magma: An approach from synthetic systems. Earth Planet. Sci. Lett., 22:294-299.

Langmuir, C. H., Bender, J. F., Bence, A. E., et al., 1977. Petrogenesis of basalts from the FAMOUS area, Mid-Atlantic Ridge. Earth Planet. Sci. Lett., 36:133-156.

Larson, E. E., Reynolds, R. L., Merrill, R., et al., 1974. Major element petrochemistry of some extrusive rocks from the volcanically active Mariana Islands. Bull. Volcanol., 38:361-377.

LaTraille, S. L., and Hussong, D. M., 1980. Crustal structure across the Mariana island arc. In Hayes, D. E. (Ed.), The Tectonic and Geologic Evolution of Southeast Asian Seas and Islands: Geophysical Monograph 23: Washington (American Geophysical Union), 209-222.

Lewis, J. F., 1973. Petrology of the ejected plutonic blocks of the Soufriere Volcano, St. Vincent, West Indies. J. Petrol., 14:81-112.

Liou, J. G., 1971. P-T stabilities of laumontite, wairakite, lawsonite, and related minerals in the system $\mathrm{CaAl}_{2} \mathrm{Si}_{2} \mathrm{O}_{8}-\mathrm{SiO}_{2}-\mathrm{H}_{2} \mathrm{O}$. J. Petrol., 12:379-411.

Louden, K. E., 1976. Magnetic anomalies in the West Philippine Basin. In Sutton, G. H., Manghnani, M. H., and Moberly, R. (Eds.), The Geophysics of the Pacific Ocean Basin and its Margin: A Volume in Honor of George P. Woollard, Geophysical Monograph 19: Washington (American Geophysical Union), 253-276.

McBirney, A. R., 1965. Compositional variations in Cenozoic calcalkaline suites of Central America. Ore. Depart. Geol. Min. Ind. Bull., 65 .

McDowell, S. D., and Elders, W. A., 1980. Authigenic layer silicate minerals in Borehole Elmore 1, Salton Sea Geothermal Field, California, USA. Contrib. Mineral. Petrol., 80:293-310.

McKenzie, D. P., 1967. Some remarks on heat flow and gravity anomalies. J. Geophys. Res., 72:6261-6273.

1969. Speculations on the consequences and causes of plate motions. Geophys. J. Roy. Astron. Soc., 18:1-32. 
Marsh, N. G., Saunders, A. D., Tarney, J., et al., 1980. Geochemistry of basalts from the Shikoku and Daito Basins, Deep Sea Drilling Project Leg 58. In Klein, G. deV., Kobayashi, K., et al., Init. Repts. DSDP, 58: Washington (U.S. Govt. Printing Office), 805-842.

Mason, A. C., Corwin, G., Rodgers, C. L., et al., 1956. Military Geology of the Palau Islands, Caroline Islands. Intelligence Division, Office of Engineer Headquarters, U.S. Army Forces Far East and Eighth U.S. Army (rear) with personnel of the U.S. Geological Survey, Washington, D.C.

Mattey, D. P., Marsh, N. G., and Tarney, J., 1980. The geochemistry, mineralogy and petrology of basalts from the West Philippine and Parece Vela Basins and from the Palau-Kyushu and West Mariana Ridges, Deep Sea Drilling Project Leg 59. In Kroenke, L., Scott, R., et al., Init. Repts. DSDP, 59: Washington (U.S. Govt. Printing Office), 753-800.

Meijer, A., 1980. Primitive arc volcanism and a boninite series: Examples from western Pacific island arcs. In Hayes, D. E. (Ed.), The Tectonic and Geologic Evolution of Southeast Asian Seas and Islands: Geophysical Monograph 23: Washington (American Geophysical Union), 271-282.

Miyashiro, A., 1973. The Troodos ophiolitic complex was probably formed in an island arc. Earth Planet. Sci. Lett., 19:218-224.

1974. Volcanic rock series in island arcs and active continental margins. Am. J. Sci., 274:321-355.

Mizuno, A., Okuda, Y., Nagumo, S., et al., 1979. Subsidence of the Daito Ridge and associated basins, north Philippine Sea. In Watkins, J., Montadert, L., and Dickerson, P. W. (Eds.), Geological and Geophysical Investigations of Continental Margins: Am. Assoc. Petrol. Geol. Mem., 29:239-243.

Mizuno, A., Okuda, Y., Tamaki, K., et al., 1975. Marine geology and geological history of the Daito Ridge area, northwestern Philippine Sea. Mar. Sci., 7:484-491(Part 1), 543-548(Part 2). (In Japanese)

Moores, E. M., and Vine, F. J., 1971. Troodos Massif, Cyprus and other ophiolites as oceanic crust: Evaluation and implications. Roy. Soc. Lond. Phil. Trans. A, 268:443-466.

Mottl, M. J., and Holland, H.D., 1978. Chemical exchange during hydrothermal alteration of basalt by seawater-1. Experimenta results for major and minor components of seawater. Geochim. Cosmochim. Acta, 42:1103-1115.

Mrozowski, C. L., and Hayes, D. E., 1980. A seismic reflection study of faulting in the Mariana fore arc. In Hayes, D. E. (Ed.), The Tectonic and Geologic Evolution of Southeast Asian Seas and Islands: Geophysical Monograph 23: Washington (American Geophysical Union), 223-234.

Muenow, D. W., Liu, N. W. K., Garcia, M. O., et al., 1980. Volatiles in submarine volcanic rocks from the East Scotia Sea back-arc basin. Earth Planet. Sci. Lett., 47:272-278.

Murauchi, S., Den, N., Asano, S., et al., 1968. Crustal structure of the Philippine Sea. J. Geophys. Res., 73:3143-3171.

Mysen, B. O., and Boettcher, A. L., 1975a. Melting of a hydrous mantle, I. Phase relations of natural peridotite at high pressures and temperatures with controlled activities of water, carbon dioxide, and hydrogen. J. Petrol., 16:520-548.

$1975 \mathrm{~b}$. Melting of a hydrous mantle, II. Geochemistry of crystals and liquids formed by anatexis of mantle peridotite at high pressures and high temperatures as a function of controlled activities of water, hydrogen, and carbon dioxide. J. Petrol., 16: 549-593.

Mysen, B. O., Kushiro, I., Nicholls., I. A., et al., 1974. A possible mantle origin for andesitic magmas: Discussion of a paper by Nicholls and Ringwood. Earth Planet. Sci. Lett., 21:221-229.

Natland, J. H., 1978. Comparison of the chemical and magnetic stratigraphy of DSDP Sites 332 and 395. In Melson, W. G., Rabinowitz, P. D., et al., Init. Repts. DSDP, 45: Washington (U.S. Govt. Printing Office), 657-677.

Natland, J. H., and Melson, W. G., 1980. Compositions of basaltic glasses from the East Pacific Rise and Siqueiros fracture zone, near $9^{\circ}$ N. In Rosendahl, B. R., Hekinian, R., et al., Init. Repts. DSDP, 54: Washington (U.S. Govt. Printing Office), 705-723.

Nicholls, 1. A., 1974. Liquids in equilibrium with peridotitic mineral assemblages at high water pressures. Contrib. Mineral. Petrol., $45: 289-316$
Nicholls. I. A., and Ringwood, A. E., 1973. Effect of water on olivine stability in tholeiites and the production of silica-saturated magmas in the island-arc environment. J. Geol., 81:285-300.

Nishimori, R. K., 1976. The petrology and geochemistry of gabbros from the Peninsular Range Batholith, California, and a model for their origin [PhD. dissert.]. University of California San Diego.

O'Hara, M. J., 1975. Is there an Icelandic mantle plume? Nature, 253:708-710.

Osborne, E. F., 1959. Role of oxygen pressure in the crystallization and differentiation of basaltic magma. Am. J. Sci., 257:609-647.

1962. Reaction series for subalkaline igneous rocks based on different oxygen pressure conditions. Am. Mineral., 47: 211-226.

1979. The reaction principle. In Yoder, H. S., Jr. (Ed.), The Evolution of the Igneous Rocks-Fiftieth Anniversary Perspectives: Princeton (Princeton University Press), pp. 133-169.

Oxburgh, E. R., and Turcotte, D. L., 1970. The thermal structure of island arcs. Geol. Soc. Am. Bull., 81:1665-1688.

Peacock, M. A., 1931. Classification of igneous rock series. J. Geol., 39:54-67.

Perfit, M. R., Gust, R. A., Bence, A. E., et al., 1980. Chemical characteristics of island arc basalts: Implications for mantle sources. Contrib. Mineral Petrol., 30:227-256.

Presnall, D. C., Dixon, J. R., O'Donnell, T. H., et al., 1979. Generation of mid-ocean ridge tholeiites. J. Petrol., 20:3-35.

Ringwood, A. E., 1974. The petrological evolution of island arc systems. J. Geol. Soc. Lond., 130:183-204.

Rodolfo, K., and Warner, R., 1980. Tectonic, volcanic, and sedimentologic significance of volcanic glasses from Site 450 in the Eastern Parece Vela Basin, Deep Sea Drilling Project Leg 59. In Kroenke, L., Scott, R., et al., Init. Repts. DSDP, 59: Washington (U.S. Govt. Printing Office), 603-608.

Saunders, A. D., and Tarney, J., 1979. The geochemistry of basalts from a back-arc spreading centre in the East Scotia Sea. Geochim. Cosmochim. Acta., 43:555-572.

Saunders, A. D., Tarney, J., and Weaver, S. D., 1980. Transverse geochemical variations across the Antarctic Peninsula: Implications for the genesis of calc-alkaline magmas. Earth Planet. Sci. Lett., $46: 344-360$.

Schmidt, R. G., 1957. Petrology of the volcanic rocks. In Schmidt, R. G., Johnson, J. H., and McCracken, R. J. (Eds.), Geology of Saipan, Mariana Islands, Part 2: Petrology and Soils, United States Geol. Surv. Prof. Paper 280-B:137-174.

Sclater, J. G., Karig, D., Lawver, L. A., et al., 1976. Heat flow, depth, and crustal thicknesses of the marginal basins of the South Philippine Sea. J. Geophys. Res., 81:309-318.

Scott, R., 1980. Petrology and geochemistry of arc tholeiites on the Palau-Kyushu Ridge, Site 448, Deep Sea Drilling Project Leg 59. In Kroenke, L., Scott, R., et al., Init. Repts. DSDP, 59: Washington (U.S. Govt. Printing Office), 803-815.

Scott, R., and Kroenke, L., 1980. Evolution of back arc spreading and arc volcanism in the Philippine Sea: Interpretation of Leg 59 DSDP results. In Hayes, D. E. (Ed.), The Tectonic and Geologic Evolution of Southeast Asian Seas and Islands, Geophysical Monograph 23: Washington (American Geophysical Union), 283-291.

Scott, R. B., Kroenke, L., Zakariadze, G., et al., 1980. Evolution of the South Philippine Sea: Deep Sea Drilling Project Leg 59 results. In Kroenke, L., Scott, R., et al., Init. Repts. DSDP, 59: Washington (U.S. Govt. Printing Office), 803-815.

Sharaskin, A. Ya., Dobretsov, N. L., and Sobolev, N. V., 1980. Marianites: The clinoenstatite bearing pillow lavas associated with the ophiolite assemblage of Mariana trench. In Panyiotou, A. (Ed.), Ophiolites: Proceedings International Ophiolite Symposium, Cyprus, 1979: Nicosia (Rep. Cyprus Min. Agric. Nat. Resources Geol. Surv. Dept.), pp. 473-479.

Shih, T.-C., 1980. Marine magnetic anomalies from the western Philippine Sea: Implications for the evolution of marginal basins. In Hayes, D. E. (Ed.), The Tectonic and Geologic Evolution of Southeast Asian Seas and Islands: Geophysical Monograph 23: Washington (American Geophysical Union), 283-291.

Sleep, N. H., and Toksöz, M. N., 1971. Evolution of marginal basins. Nature, 33:548-550. 
Smith, A. L., and Carmichael, 1. S. E., 1968. Quaternary lavas from the southern Cascades, Western U.S.A. Contrib. Mineral. Petrol., 19:212-238.

Stacey, F. D., 1977. Physics of the Earth (2nd edition): New York (Wiley).

Stark, J. T., 1963. Petrology of the volcanic rocks of Guam. U.S. Geol. Surv. Prof. Paper 403-C: Washington (U.S. Govt. Printing Office), C1-C32.

Stern, R. J., 1979. On the origin of andesite in the northern Mariana island arc: Implications from Agrigan. Contrib. Mineral Petrol., 68:207-219.

Stolper, E., 1980. A phase diagram for mid-ocean ridge basalts: Preliminary results and implications for petrogenesis. Contrib. Mineral. Petrol., 74:13-27.

Sun, S.-S., and Nesbitt, R. W., 1978. Geochemical regularities and genetic significance of ophiolitic basalts. Geology, 6:689-693.

Tarney, J., Saunders, A. D., Mattey, D. P., et al., 1981. Geochemical aspects of back-arc spreading in the Scotia Sea and western $\mathrm{Pa}$ cific. Phil. Trans. R. Soc. Lond. A, 300:263-285.

Tarney, J., Wood, D. A., Varet, J., et al., 1979. Nature of mantle heterogeneity in the North Atlantic: evidence from Leg 49 basalts. In Talwani, M., Harrison, C. G. A., and Hayes, D. E., (Eds.), Deep Drilling Results in the Atlantic Ocean: Ocean Crust, Maurice Ewing Series 2: Washington (American Geophysical Union), pp. 285-301.

Thorpe, R. S., Potts, P. J., and Francis, P. W., 1976. Rare earth data and petrogenesis of andesite from the north Chilean Andes. Contrib. Mineral. Petrol., 54:65-78.

Tiezzi, L. J., and Scott, R. B., 1980. Crystal fractionation in a cumulate gabbro, Mid-Atlantic Ridge, $26^{\circ}$ N. J. Geophys. Res., $85: 5438: 5454$.

Toksöz, M. N., and Bird, P., 1978. Formation and evolution of marginal basins and continental plateaus. In Talwani, M., Pitman, W. C., III (Eds.), Island Arcs, Deep Sea Trenches and Back-arc Basins: Maurice Ewing Series 1: Washington (American Geophysical Union), pp. 379-393.

Toksöz, M. N., and Hsui, A. T., 1978. Numerical studies on back-arc convection and the formation of marginal basins. In Töksoz, M. N. (Ed.), Numerical Modeling in Geodynamics: Tectonophysics, 50:177-196.
Tomasson, J., and Kristmannsdottir, H., 1972. High temperature alteration minerals and thermal brines, Reykjanes, Iceland. Contrib. Mineral. Petrol., 36:123-134.

Tracey, J. I., Jr., and Stark, J. T., 1963. Trace elements in the volcanic Rocks of Guam: In Stark, J. T. (Ed.), Petrology of the Volcanic Rocks of Guam: U.S. Geol. Surv. Prof. Paper 403-C: Washington (U.S. Govt. Printing Office), C27-C32.

Uyeda, S., and Kanamori, H., 1979. Back-arc opening and the mode of subduction. J. Geophys. Res., 84:1049-1062.

Wager, L. R., and Brown, G. M., 1967. Layered Igneous Rocks: San Francisco (Freeman).

Watts, A. B., Weissel, J. K., and Larson, R. L., 1977. Sea-floor spreading in marginal basins of the western Pacific. Tectonophysics, 37:167-182.

Weaver, S. D., Saunders, A. D., Pankhurst, R. J., et al., 1979. A geochemical study of magmatism associated with the initial stages of back-arc spreading. Contrib. Mineral. Petrol., 68:151-169.

Wood, D. A., Joron, J.-L., Marsh, N. G. et al., 1980. Major- and trace element variations in basalts from the North Philippine Sea drilled during Deep Sea Drilling Project Leg 58: A comparative study of back-arc basalts with lava series from Japan and midocean ridges. In Klein, G. deV., Kobayashi, K., et al., Init. Repts. DSDP, 58: Washington (U.S. Govt. Printing Office), 873-894.

Wood, D. A., Mattey, D. P., Joron, J.-L., et al., 1980. A geochemical study of 17 selected samples from the basement cores recovered at Sites 447, 448, 449, 450, and 451, Deep Sea Drilling Project Leg 59. In Kroenke, L., Scott, R., et al., Init. Repts. DSDP, 59: Washington (U.S. Govt. Printing Office), 743-752.

Wood, D. A., Tarney, J., Varet, J., et al., 1979. Geochemistry of basalts drilled in the North Atlantic by IPOD Leg 49: Implications for mantle heterogeneity. Earth Planet. Sci. Lett., 42:77-97.

Wyllie, P. J., 1971. Role of water in magma generation and initiation of diapiric uprise in the mantle. J. Geophys. Res., 76:1328-1338.

Yoder, H. S., Jr., 1969. Calcalkalic andesites: Experimental data bearing on the origin of their assumed characteristics. In McBirney, A. R. (Ed.), Proceedings of the Andesite Conference: Oreg. Dep. Geol. Miner. Ind. Bull., 65:77-89.

Yoder, H. S., Jr., and Tilley, C. E., 1962. Origin of basalt magmas: An experimental study of natural and synthetic rock systems. $J$. Petrol., 3:342-532. 